\title{
Metalated Nitriles: Chelation-Controlled \\ Cyclizations to cis and trans Hydrindanes and
}

\section{Decalins}

Fraser F. Fleming, Viet Anh Vu, Brian C. Shook, Moshfiqur Raman and Omar W. Steward.

Department of Chemistry and Biochemistry, Duquesne University, Pittsburgh, Pennsylvania 15282-1530.

Supporting Information Table of Contents

\begin{tabular}{|c|c|c|c|c|}
\hline Compound & Procedure & ${ }^{1}$ H NMR & ${ }^{13} \mathrm{C}$ NMR & ORTEP \\
\hline HO & S4 & S20 & S21 & \\
\hline$\underset{\text { HO }}{t}$ & S4 & S22 & S23 & \\
\hline & S5 & S24 & S25 & \\
\hline if & S5 & S26 & S27 & \\
\hline$\underbrace{19 b}_{\mathrm{HO}}$ & S5 & S28 & & \\
\hline 诲 $\mathrm{CN}$ & S6 & S29 & S30 & \\
\hline $19 a$ & S6 & S31 & S32 & \\
\hline
\end{tabular}




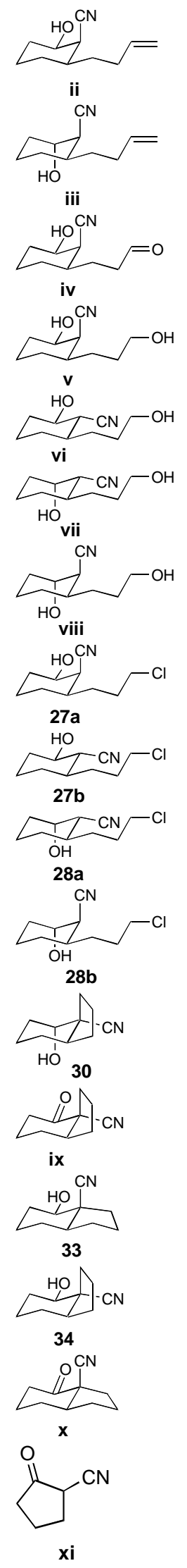

$\begin{array}{lll}\text { S7 } & \text { S33 } & \text { S34 } \\ \text { S7 } & \text { S35 } & \text { S36 }\end{array}$

$\begin{array}{lll}\text { S7 } & \text { S37 } & \text { S38 }\end{array}$

$\begin{array}{lll}\text { S8 } & \text { S39 } & \text { S40 }\end{array}$

$\begin{array}{lll}\text { S8 } & \text { S41 } & \text { S42 }\end{array}$

$\begin{array}{lll}\text { S9 } & \text { S43 } & \text { S44 }\end{array}$

$\begin{array}{lll}\text { S9 } & \text { S45 } & \text { S46 }\end{array}$

$\begin{array}{lll}\text { S10 } & \text { S47 } & \text { S48 }\end{array}$

$\begin{array}{lll}\text { S10 } & \text { S49 } & \text { S50 }\end{array}$

$\begin{array}{lll}\text { S11 } & \text { S51 } & \text { S52 }\end{array}$

$\begin{array}{lll}\text { S11 } & \text { S53 } & \text { S54 }\end{array}$

$\begin{array}{lll}\text { S12 } & \text { S55 } & \text { S56 }\end{array}$

$\begin{array}{lll}\text { S12 } & \text { S57 } & \text { S58 }\end{array}$

$\begin{array}{lll}\text { S13 } & \text { S59 } & \text { S60 }\end{array}$

$\begin{array}{lll}\text { S13 } & \text { S61 } & \text { S62 }\end{array}$

$\begin{array}{lll}\text { S14 } & \text { S63 } & \text { S64 }\end{array}$

$\begin{array}{lll}\text { S14 } & \text { S65 } & \text { S66 }\end{array}$




\begin{tabular}{|c|c|c|c|c|}
\hline . & S15 & S67 & S68 & \\
\hline $4^{\mathrm{HO} \mathrm{CN}^{\mathrm{CN}}} \mathrm{Tl}_{\mathrm{Cl}}$ & S15 & S69 & S70 & \\
\hline${ }_{37 \mathrm{~b}}^{\mathrm{Cl}}$ & S15 & S71 & S72 & \\
\hline$\underbrace{18}_{\mathrm{HO}} \tau_{38}^{\mathrm{CN}}$ & S15 & S73 & S74 & \\
\hline & S16 & S75 & S76 & $\begin{array}{c}\text { S77 } \\
\text { CCDC } \\
626356\end{array}$ \\
\hline$\underbrace{\mathrm{NO}_{2}}_{40}{ }^{\mathrm{xii}}=\mathrm{N}$ & S17 & S78 & S79 & \\
\hline$\frac{1}{0}$ & S17 & S80 & S81 & $\begin{array}{c}\text { S82 } \\
\text { CCDC } \\
626357\end{array}$ \\
\hline 语- & S18 & S83 & S84 & \\
\hline (3) & $\mathrm{S} 18$ & S85 & S86 & \\
\hline HO & S18 & S87 & S88 & \\
\hline$\underbrace{44}_{x v}$ & S19 & S89 & S90 & \\
\hline
\end{tabular}


$\left(1 S^{*}, 2 S^{*}, 6 S\right)$-2-hydroxy-7,7-dimethylbicyclo[4.4.0]decanecarbonitrile (22) and $\left(1 R^{*}, 2 S^{*}, 6 S\right)$ 2-hydroxy-7,7-dimethylbicyclo[4.4.0]decanecarbonitrile (23). A THF solution (1 M) of 20b ${ }^{1}$ (16 mg, $0.0744 \mathrm{mmol}$ ) was added to a $-78{ }^{\circ} \mathrm{C}$, THF solution of $\mathrm{LiNEt}_{2}$ (2.5 equiv), prepared from a hexanes solution of BuLi (2.5 equiv) and neat $\mathrm{HNEt}_{2}$ (2.7 equiv), and the resulting mixture allowed to warm slowly $(\sim 4 \mathrm{~h})$ to rt. After $8 \mathrm{~h}$ saturated, aqueous $\mathrm{NH}_{4} \mathrm{Cl}$ was added and the aqueous phase extracted with EtOAc. The combined organic extracts were washed with brine, dried $\left(\mathrm{MgSO}_{4}\right)$, and concentrated. The resulting material was purified by radial chromatography ( $1 \mathrm{~mm}$ plate, 3:7 EtOAc:hexanes) to afford $7 \mathrm{mg} \mathrm{(40 \% )} \mathrm{of} 22$ as a white crystalline solid (mp $\left.100-101{ }^{\circ} \mathrm{C}\right)$ and $7 \mathrm{mg}(40 \%)$ of 23 as an oil. For 22: IR (KBr) 3457, $2234 \mathrm{~cm}^{-1} ;{ }^{1} \mathrm{H}$ NMR $\delta 0.89$ (s, 3H), 1.27 (s, 3H), 1.33-1.83 (m, 12H), $1.90(\mathrm{dd}, J=11,4 \mathrm{~Hz}, 1 \mathrm{H}), 2.31$ (br s, 1H), 3.79-3.84 (m, 1H); ${ }^{13} \mathrm{C}$ NMR $\delta 19.1,19.7,22.5,27.7,28.6,29.3,30.3,34.0,35.2,42.9,44.6,71.6,126.1$; MS m/e $207(\mathrm{M}+)$. For 23: (mp 88-90 $\left.{ }^{\circ} \mathrm{C}\right)$; IR (KBr) 3435, 2959, 2930, $2242 \mathrm{~cm}^{-1} ;{ }^{1} \mathrm{H}$ NMR $\delta$ $0.91(\mathrm{~s}, 3 \mathrm{H}), 1.04(\mathrm{~s}, 3 \mathrm{H}), 1.15-1.28(\mathrm{~m}, 2 \mathrm{H}), 1.33-1.52(\mathrm{~m}, 3 \mathrm{H}), 1.54-1.92(\mathrm{~m}, 8 \mathrm{H}), 1.98-2.10$ (m, 1H), $3.83(\mathrm{t}, J=2.8 \mathrm{~Hz}, 1 \mathrm{H}) ;{ }^{13} \mathrm{C}$ NMR $\delta$ 19.4, 20.2, 20.4, 23.8, 30.6, 31.7, 33.2, 33.2, 41.2, 43.9, 44.0, 71.9, 123.7; MS m/e $208(\mathrm{M}+\mathrm{H})$.

A PhH solution $(1 \mathrm{~mL})$ of $\mathbf{2 0 b}^{41}(110 \mathrm{mg}, 0.45 \mathrm{mmol})$ was added to a rt, $\mathrm{PhH}$ solution $(1 \mathrm{~mL})$ of LiNEt $_{2}(1.36 \mathrm{mmol})$, prepared by reacting $\mathrm{Et}_{2} \mathrm{NH}(0.14 \mathrm{~mL}, 1.36 \mathrm{mmol})$ with $\mathrm{BuLi}(0.85 \mathrm{~mL}$, $1.36 \mathrm{mmol}$ ) at $\mathrm{rt}$ for $15 \mathrm{~min}$. After $16 \mathrm{~h}$ saturated aqueous $\mathrm{NH}_{4} \mathrm{Cl}$ was added, and then the aqueous phase was extracted with EtOAc. The combined extracts were washed with brine, dried $\left(\mathrm{Mg}_{2} \mathrm{SO}_{4}\right)$, and concentrated to give $89 \mathrm{mg}(95 \%)$ of the cis-decalin 23 analytically pure by spectral analysis. 
(1S*, 6S*)-7,7-dimethyl-2-oxobicyclo[4.4.0]decanecarbonitrile (i) Solid TPAP (0.05 equiv) was added in one portion to a rt, $\mathrm{CH}_{2} \mathrm{Cl}_{2}$ solution $(0.05 \mathrm{M})$ of trans-hydroxynitrile $22(18 \mathrm{mg}, 87$ $\mu \mathrm{mol})$, NMO (1.5 equiv) and powdered 4A molecular sieves $(500 \mathrm{mg} / \mathrm{mmol})$. After $8 \mathrm{~h}$ the suspension was filtered through a short pad of silica, eluting with $\mathrm{CH}_{2} \mathrm{Cl}_{2}$. The filtrate was concentrated and purified by radial chromatography ( $1 \mathrm{~mm}$ plate 1:9, EtOAc:hexanes) to afford, after radial chromatography ( $1 \mathrm{~mm}$ plate, 1:9 EtOAc:hexanes), $17 \mathrm{mg}(95 \%)$ of $\mathbf{i}$ as a white crystalline solid (CCDC 183550) spectrally identical to material isolated previously. ${ }^{41}$

$\left(1 R^{*}, 6 S^{*}\right)$-7,7-dimethyl-2-oxobicyclo[4.4.0]decanecarbonitrile (19b). Solid TPAP (0.05 equiv) was added in one portion to a rt, $\mathrm{CH}_{2} \mathrm{Cl}_{2}$ solution $(0.05 \mathrm{M})$ of cis-hydroxynitrile $23(6 \mathrm{mg}$, $29 \mu \mathrm{mol})$, NMO (1.5 equiv) and powdered 4A molecular sieves $(500 \mathrm{mg} / \mathrm{mmol})$. After $8 \mathrm{~h}$ the suspension was filtered through a short pad of silica, eluting with $\mathrm{CH}_{2} \mathrm{Cl}_{2}$. The filtrate was concentrated and purified by radial chromatography ( $1 \mathrm{~mm}$ plate 1:9, EtOAc:hexanes) to afford, after radial chromatography (1 mm plate, 1:9 EtOAc:hexanes), $5 \mathrm{mg}(83 \%)$ of $\mathbf{1 9 b}$ as a white crystalline solid (CCDC 183548) spectrally identical to material isolated previously. ${ }^{41}$

$\left(1 S^{*}, 2 S^{*}, 6 S^{*}\right)$-2-hydroxybicyclo[4.4.0]decanecarbonitrile (25). Nitrile $20 \mathrm{a}^{41}$ (19 mg, 0.088 mmol) having the in the axial orientation was cyclized employing the procedure described for 20b, to afford, after radial chromatography ( $1 \mathrm{~mm}$ plate, 3:7 EtOAc:hexanes), $12 \mathrm{mg}(77 \%)$ of 25 as a white crystalline solid (mp 80-81 ${ }^{\circ} \mathrm{C}$ ): IR (KBr) 3450, $2230 \mathrm{~cm}^{-1} ;{ }^{1} \mathrm{H}$ NMR $\delta 1.40-2.40$ $(\mathrm{m}, 16 \mathrm{H}), 3.87-3.96(\mathrm{~m}, 1 \mathrm{H})$; MS m/e $179\left(\mathrm{M}^{+}\right)$. Following the same procedure, cyclization of $20 \mathrm{a}^{41}(16 \mathrm{mg}, 0.0744 \mathrm{mmol})$ having the nitrile in the equatorial orientation afforded, after radial chromatography (1 mm plate, 3:7 EtOAc:hexanes), $8 \mathrm{mg}(63 \%)$ of 25 as a white crystalline solid. 
(1 $\left.R^{*}, 6 S^{*}\right)$-2-oxobicyclo[4.4.0]decanecarbonitrile (19a). Solid TPAP (0.05 equiv) was added in one portion to a rt, $\mathrm{CH}_{2} \mathrm{Cl}_{2}$ solution $(0.05 \mathrm{M})$ of cis-hydroxynitrile $25(10 \mathrm{mg}, 0.056 \mathrm{mmol})$, NMO (1.5 equiv) and powdered 4A molecular sieves $(500 \mathrm{mg} / \mathrm{mmol})$. After $8 \mathrm{~h}$ the suspension was filtered through a short pad of silica, eluting with $\mathrm{CH}_{2} \mathrm{Cl}_{2}$. The filtrate was concentrated and purified by radial chromatography (1mm plate 1:9, EtOAc:hexanes) to afford, after radial chromatography (1 $\mathrm{mm}$ plate, 1:9 EtOAc:hexanes), $9 \mathrm{mg}(91 \%)$ of $\left(\mathbf{1}^{*}, \mathbf{6 S}^{*}\right)-\mathbf{2}-$ oxobicyclo[4.4.0]decanecarbonitrile (19a) as a white crystalline solid (CCDC 139957) spectrally identical to material isolated previously. ${ }^{2}$

\section{2-(tert-Butyldimethylsilyloxy)-6-(1-butene)-1-cyclohexenyl-1-carbonitrile}

Bromomagnesium-1-but-3-ene was prepared by the dropwise addition (20 min) of 4-bromo-1butene $(1.35 \mathrm{~g}, 10 \mathrm{mmol})$ to a THF $(50 \mathrm{~mL})$ room temperature slurry of magnesium metal (316 $\mathrm{mg}, 13 \mathrm{mmol}$ ) with constant sonication. The resulting cloudy solution was then stirred at room temperature for $2 \mathrm{~h}$ to ensure complete consumption of magnesium and then cooled to $-78{ }^{\circ} \mathrm{C}$. A THF solution of 6-oxocyclohex-1-ene-1-carbonitrile $(1.1 \mathrm{~g}, 9.09 \mathrm{mmol})$ was then added dropwise, over $5 \mathrm{~min}$, and after $45 \mathrm{~min}$ the resulting solution was allowed to warm to room temperature. After $30 \mathrm{~min}$ TBDMSCl $(2.26 \mathrm{~g}, 13.64 \mathrm{mmol})$ was then added. After a further $15 \mathrm{~h}$ saturated aqueous $\mathrm{NH}_{4} \mathrm{Cl}$ was added, the aqueous phase extracted with ethyl acetate, and the combined extracts washed with brine, dried $\left(\mathrm{MgSO}_{4}\right)$ and concentrated. The crude product was purified by radial chromatography ( $4 \mathrm{~mm}$ plate, $1: 5 \mathrm{EtOAc/hexanes)}$ to afford $1.87 \mathrm{~g}(71 \%)$ of 26 as a colorless oil: IR (film) 3077, 2208, $1630 \mathrm{~cm}^{-1}$; ${ }^{1} \mathrm{H}$ NMR $\delta 0.22(\mathrm{~s}, 6 \mathrm{H}), 0.97$ (s, $9 \mathrm{H}$ ), 
$1.04-2.33(\mathrm{~m}, 11 \mathrm{H}), 4.94-5.06(\mathrm{~m}, 2 \mathrm{H}) 5.74-5.87(\mathrm{~m}, 1 \mathrm{H}) ;{ }^{13} \mathrm{C}$ NMR $\delta-4.2,-3.8,18.0,19.8$ $25.5,26.4,30.8,30.9,33.6,34.6,95.7,114.8,118.3,138.0,165.4$.

2-(But-2-enyl)-6-hydroxycyclohexanecarbonitriles: Incremental portions of solid $\mathrm{NaBH}_{4}(289$ $\mathrm{mg}, 7.63 \mathrm{mmol})$ were added over $20 \mathrm{~min}$ to a room temperature, pyridine-methanol $(3: 1,20 \mathrm{~mL})$ solution of 26 (1.85 g, $6.35 \mathrm{mmol})$ with vigorous stirring. After $12 \mathrm{~h}$ saturated aqueous $\mathrm{NH}_{4} \mathrm{Cl}$ was added, and the aqueous phase was extracted with ethyl acetate, the organic extracts were combined and washed successively with $10 \%$ aqueous $\mathrm{HCl}$ and brine, dried $\left(\mathrm{MgSO}_{4}\right)$ and concentrated. The crude mixture of alcohols were purified by radial chromatography $(4 \mathrm{~mm}$ plate, 1:19 EtOAc/hexanes) to afford, $627 \mathrm{mg}(55 \%)$ of $\left(\mathbf{1} \boldsymbol{R}^{*}, \mathbf{2} \boldsymbol{R}^{*}, \mathbf{6} \boldsymbol{R}^{*}\right)$-2-(But-2-enyl)-6hydroxycyclohexanecarbonitrile (ii) and $285 \mathrm{mg}(25 \%)$ of (1R*, 2S*, 6R*)-2-(But-2-enyl)-6hydroxycyclohexanecarbonitrile (iii) as colorless oils. For ii: IR (film) 3439, 3077, 2240, 1641 $\mathrm{cm}^{-1} ;{ }^{1} \mathrm{H}$ NMR $\delta 1.21-1.35(\mathrm{~m}, 2 \mathrm{H}), 1.52-2.16(\mathrm{~m}, 10 \mathrm{H}), 3.15(\mathrm{br} \mathrm{s}, 1 \mathrm{H}), 3.60-3.76(\mathrm{~m}, 1$ H), 4.95 - 5.10 (m, $2 \mathrm{H}), 5.74$ - $5.82(\mathrm{~m}, 1 \mathrm{H}) ;{ }^{13} \mathrm{C} \mathrm{NMR} \delta 23.3,27.7,30.7,31.7,33.1,37.3,42.8$, 70.1, 115.4, 118.2,137.6; HRMS (ESI) calcd. For $\mathrm{C}_{11} \mathrm{H}_{17} \mathrm{NONa}^{+}$202.1202, found 202.1208. For iii: IR (film) 3443, 3077, 2241, $1641 \mathrm{~cm}^{-1}$; ${ }^{1} \mathrm{H}$ NMR $\delta 1.29-1.44$ (m, $\left.2 \mathrm{H}\right), 1.54-2.15$ (m, 10 H), $2.86($ br s, $1 \mathrm{H}), 4.22(\mathrm{br} \mathrm{s}, 1 \mathrm{H}), 4.96-5.09(\mathrm{~m}, 2 \mathrm{H}), 5.74-5.84(\mathrm{~m}, 1 \mathrm{H}) ;{ }^{13} \mathrm{C}$ NMR $\delta$ 19.0, 28.0, 30.1, 30.8, 32.3, 32.4, 39.6, 67.2, 115.2, 119.1, 137.8; HRMS (ESI) calcd. for $\mathrm{C}_{11} \mathrm{H}_{17} \mathrm{NONa}^{+}$202.1202, found 202.1196.

$\left(1 R^{*}, 2 R^{*}, 6 R^{*}\right)$-2-hydroxy-6-(3-oxopropyl)cyclohexanecarbonitrile (iv): Ozone was passed through a $-78{ }^{\circ} \mathrm{C}, \mathrm{CH}_{2} \mathrm{Cl}_{2}$ solution (5 mL) of 6-(1-butene)-2-hydroxycyclohexanecarbonitrile (ii) (20 mg, $0.11 \mathrm{mmol}$ ) until the persistence of the blue color indicative of excess ozone. The 
resulting solution was then purged with $\mathrm{N}_{2}$ until dissipation of the blue color, and then neat dimethyl sulfide $(0.25 \mathrm{~mL}, 0.85 \mathrm{mmol})$ was added. The solution was then allowed to warm to room temperature, stirred for $12 \mathrm{~h}$, and then concentrated before being redissolved in EtOAc (20 $\mathrm{mL})$. The crude aldehyde residue was then washed with brine, dried $\left(\mathrm{MgSO}_{4}\right)$, concentrated and purified by radial chromatography ( $1 \mathrm{~mm}$ plate, $3: 2$ EtOAc/hexanes), to afford $13 \mathrm{mg}(64 \%)$ of iv as a colorless oil; IR (film) 3339, 2239, $1721 \mathrm{~cm}^{-1} ;{ }^{1} \mathrm{H}$ NMR $\delta 1.16-1.31$ (m, $\left.2 \mathrm{H}\right), 1.50-2.18$ $(\mathrm{m}, 9 \mathrm{H}), 2.52(\mathrm{t}, J=7.4 \mathrm{~Hz}, 1 \mathrm{H}), 3.14($ br s, $1 \mathrm{H}), 3.60-3.70(\mathrm{~m}, 1 \mathrm{H}), 9.77(\mathrm{~s}, 1 \mathrm{H}) ;{ }^{13} \mathrm{C} \mathrm{NMR} \delta$ $23.1,26.2,27.4,31.4,37.1,40.6,42.1,69.8,117.9,201.3$.

2-Hydroxy-6-(3-hydroxypropyl)cyclohexanecarbonitriles (v, vi). By reduction of iv: Incremental portions of solid $\mathrm{NaBH}_{4}(51 \mathrm{mg}, 1.34 \mathrm{mmol})$ were added over $10 \mathrm{~min}$ to a room temperature, methanolic solution $(15 \mathrm{~mL})$ of iv $(100 \mathrm{mg}, 0.56 \mathrm{mmol})$ with vigorous stirring. After $2 \mathrm{~h}$ saturated aqueous $\mathrm{NH}_{4} \mathrm{Cl}$ was added, the aqueous phase was separated and then extracted with ethyl acetate, the organic extracts were combined and washed with brine, dried $\left(\mathrm{MgSO}_{4}\right)$ and concentrated. Purification of the crude alcohols by radial chromatography (1 mm plate, 4:1 EtOAc/hexanes) afforded $28 \mathrm{mg}(27 \%)$ of $\left(\mathbf{1} \boldsymbol{R}^{*}, \mathbf{2} \boldsymbol{R}^{*}, \mathbf{6} \boldsymbol{R}^{*}\right)$-2-hydroxy-6-(3hydroxypropyl)cyclohexanecarbonitrile (v) as a colorless oil and $29 \mathrm{mg}(28 \%)$ of $\left(\mathbf{1} \boldsymbol{R}^{*}, \mathbf{2} \boldsymbol{R}^{*}\right.$, 6R*)-2-hydroxy-6-(3-hydroxypropyl)cyclohexanecarbonitrile (vi), as a crystalline solid, m.p. 96-97 ${ }^{\circ} \mathrm{C}$. For v: IR (film) 3444, $2241 \mathrm{~cm}^{-1} ;{ }^{1} \mathrm{H}$ NMR $\delta 1.22-2.20(\mathrm{~m}, 13 \mathrm{H}), 3.17$ (br s, $\left.1 \mathrm{H}\right)$, 3.60-3.75 (m, $1 \mathrm{H}), 3.65(\mathrm{t}, J=5.9 \mathrm{~Hz}, 2 \mathrm{H}) ;{ }^{13} \mathrm{C} \mathrm{NMR} \delta 23.3,27.8,29.7,30.4,31.6,38.0,42.3$, 62.6, 70.0, 118.1; HRMS (ESI) calcd. for $\mathrm{C}_{10} \mathrm{H}_{17} \mathrm{NO}_{2} \mathrm{Na}^{+}$206.1151, found 206.1147. For vi: IR (film) 3416, $2239 \mathrm{~cm}^{-1} ;{ }^{1} \mathrm{H}$ NMR $\delta 0.77$ - 0.91 (m, $\left.2 \mathrm{H}\right), 1.21$ - 1.88 (m, $\left.9 \mathrm{H}\right), 2.00-2.10$ (m, $\left.1 \mathrm{H}\right)$, $2.15(\mathrm{t}, J=10.3 \mathrm{~Hz}, 1 \mathrm{H}), 2.67(\mathrm{br} \mathrm{s}, 1 \mathrm{H}), 3.66(\mathrm{t}, J=5.9 \mathrm{~Hz}, 2 \mathrm{H}), 3.67-3.75(\mathrm{~m}, 1 \mathrm{H}) ;{ }^{13} \mathrm{C}$ 
NMR $\delta$ 23.0, 29.4, 29.8, 30.8, 33.9, 38.9, 45.0, 62.8, 71.3, 120.8; HRMS (ESI) calcd. for $\mathrm{C}_{10} \mathrm{H}_{17} \mathrm{NO}_{2} \mathrm{Na}^{+} 206.1151$, found 206.1162. By ozonolysis of iv: Ozone was passed through a -78 ${ }^{\circ} \mathrm{C}, \mathrm{CH}_{2} \mathrm{Cl}_{2}$ solution $(20 \mathrm{~mL})$ of iv $(30 \mathrm{mg}, 0.17 \mathrm{mmol})$ until the persistence of a blue color indicative of excess ozone. The resulting solution was then purged with $\mathrm{N}_{2}$ until dissipation of the blue color, and then neat dimethyl sulfide $(0.25 \mathrm{~mL}, 0.85 \mathrm{mmol})$ was added. The solution was then allowed to warm to room temperature, stirred for $12 \mathrm{~h}$ and then concentrated. The crude aldehyde was then dissolved in a room temperature $\mathrm{MeOH}$ solution $(15 \mathrm{~mL})$ and incremental portions of solid $\mathrm{NaBH}_{4}(16 \mathrm{mg}, 0.40 \mathrm{mmol})$ were added over $5 \mathrm{~min}$ with vigorous stirring. After $2 \mathrm{~h}$ saturated aqueous $\mathrm{NH}_{4} \mathrm{Cl}$ was added, the aqueous phase was extracted with ethyl acetate, the organic extracts were combined and washed with brine, dried $\left(\mathrm{MgSO}_{4}\right)$, and concentrated. The crude alcohols were purified by radial chromatography ( $1 \mathrm{~mm}$ plate, 4:1 EtOAc/hexanes) to afford $10 \mathrm{mg}(33 \%)$ of vii and $13 \mathrm{mg}(42 \%)$ of viii.

2-Hydroxy-6-(3-hydroxypropyl)cyclohexanecarbonitrile (vii and viii): Ozone was passed through a $-78{ }^{\circ} \mathrm{C}, \mathrm{CH}_{2} \mathrm{Cl}_{2}$ solution $(20 \mathrm{~mL})$ of iii $(20 \mathrm{mg}, 0.11 \mathrm{mmol})$ until the persistence of a blue color indicative of excess ozone. The resulting solution was then purged with $\mathrm{N}_{2}$ until dissipation of the blue color, and then neat dimethyl sulfide $(0.25 \mathrm{~mL}, 0.85 \mathrm{mmol})$ was added. The solution was then allowed to warm to room temperature, stirred for $12 \mathrm{~h}$ and then concentrated. The residue was then redissolved in a room temperature, $\mathrm{MeOH}$ solution $(15 \mathrm{~mL})$ and then incremental portions of solid $\mathrm{NaBH}_{4}(11 \mathrm{mg}, 0.27 \mathrm{mmol})$ were added over 5 min with vigorous stirring. After $2 \mathrm{~h}$ saturated, aqueous $\mathrm{NH}_{4} \mathrm{Cl}$ was added, the aqueous phase was extracted with ethyl acetate, the organic extracts were combined and washed with brine, dried $\left(\mathrm{MgSO}_{4}\right)$ and concentrated. The crude alcohols were purified by radial chromatography $(1 \mathrm{~mm}$ 
plate, 4:1 EtOAc/hexanes) to afford $7.4 \mathrm{mg}(36 \%)$ of $\left(1 S^{*}, 2 S^{*}, 6 R^{*}\right)$-2-hydroxy-6-(3hydroxypropyl)cyclohexanecarbonitrile (vii) and $7.6 \mathrm{mg}(37 \%)$ of $\left(1 R^{*}, \mathbf{2 S *}, \mathbf{6} \boldsymbol{R}^{*}\right)-\mathbf{2 -}$ hydroxy-6-(3-hydroxypropyl)cyclohexanecarbonitrile (viii), as colorless oils. For vii: IR (film) 3417, $2239 \mathrm{~cm}^{-1}$; ${ }^{1} \mathrm{H}$ NMR $\delta 0.92-1.05(\mathrm{~m}, 1 \mathrm{H}), 1.28-2.02(\mathrm{~m}, 12 \mathrm{H}), 2.44(\mathrm{~d}, J=10.3$ $\mathrm{Hz}, 1 \mathrm{H}), 3.65$ (t, J=5.2 Hz, $2 \mathrm{H}), 4.19$ (s, $1 \mathrm{H}) ;{ }^{13} \mathrm{C}$ NMR $\delta$ 19.0, 28.1, 29.7, 30.0, 32.7, 39.7, 41.3, 62.6, 67.1, 119.2; HRMS (ESI) calcd. for $\mathrm{C}_{10} \mathrm{H}_{17} \mathrm{NO}_{2}$ 206.1151, found 206.1163. For $\mathbf{x}$ : IR (film) 3394, $2239 \mathrm{~cm}^{-1}$; ${ }^{1} \mathrm{H}$ NMR $\delta 1.33-2.30(\mathrm{~m}, 13 \mathrm{H}), 2.88(\mathrm{~s}, 1 \mathrm{H}), 3.67$ (t, J=5.9 Hz, 2H), $4.24(\mathrm{~s}, 1 \mathrm{H}) ;{ }^{13} \mathrm{C}$ NMR $\delta 19.0,28.1,29.5,29.7,30.0,32.7,39.7,62.6,67.0,119.2$; HRMS (ESI) calcd. for $\mathrm{C}_{10} \mathrm{H}_{17} \mathrm{NO}_{2}$ 206.1151, found 206.1158.

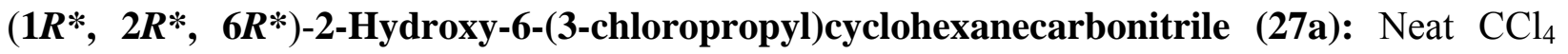
$(0.65 \mathrm{~mL}, 6.69 \mathrm{mmol})$ was added to a room temperature, $\mathrm{CH}_{2} \mathrm{Cl}_{2}$ solution $(10 \mathrm{~mL})$ of triphenyl phosphine (195 mg, $0.74 \mathrm{mmol})$ and vii $(68 \mathrm{mg}, 0.37 \mathrm{mmol})$. After $12 \mathrm{~h}$ the reaction was diluted with a mixture of ether-pentane $(1: 1,20 \mathrm{~mL})$ and then filtered through a short pad of silica gel (2 $\mathrm{cm} \times 2 \mathrm{~cm}$ ). Evaporation of the solvent and purification by radial chromatography (1 $\mathrm{mm}$ plate, 3:7 EtOAc/hexanes) afforded $64 \mathrm{mg}(86 \%)$ of $27 \mathrm{a}$, as a white crystalline solid, m.p. $\left(64-65^{\circ} \mathrm{C}\right)$; IR (film) 3440, $2241 \mathrm{~cm}^{-1} ;{ }^{1} \mathrm{H}$ NMR $\delta 1.16-1.30(\mathrm{~m}, 2 \mathrm{H}), 1.50-2.00(\mathrm{~m}, 8 \mathrm{H}), 2.48(\mathrm{br} \mathrm{d}$, $J=4.4 \mathrm{~Hz}, 1 \mathrm{H}), 3.13(\mathrm{~s}, 1 \mathrm{H}), 3.51(\mathrm{t}, J=5.9 \mathrm{~Hz}, 2 \mathrm{H}), 3.66(\mathrm{dt}, J=10.3,4.4 \mathrm{~Hz}, 1 \mathrm{H}) ;{ }^{13} \mathrm{C}$ NMR $\delta$ 23.3, 27.6, 31.6, 32.9, 37.6, 42.5, 44.5, 47.5, 70.1, 118.1; HRMS (EI) calcd. for $\mathrm{C}_{10} \mathrm{H}_{16} \mathrm{ClNO}$ 201.0915, found 201.0867.

$\left(1 S^{*}, 2 R^{*}, 6 R^{*}\right)$-2-Hydroxy-6-(3-chloropropyl)cyclohexanecarbonitrile (27b): Neat $\mathrm{CCl}_{4}$ $(0.35 \mathrm{~mL}, 0.98 \mathrm{mmol})$ was added to a room temperature, $\mathrm{CH}_{2} \mathrm{Cl}_{2}$ solution $(5 \mathrm{~mL})$ of triphenyl 
phosphine (30 mg, $0.11 \mathrm{mmol})$ and vii $(10 \mathrm{mg}, 0.05 \mathrm{mmol})$. After $12 \mathrm{~h}$ the reaction was diluted with a mixture of ether-pentane $(1: 1,20 \mathrm{~mL})$ and then filtered through a short pad of silica gel (2 $\mathrm{cm} \times 2 \mathrm{~cm}$ ). Evaporation of the solvent and purification by radial chromatography (1 mm plate, 3:7 EtOAc/hexanes) afforded $9 \mathrm{mg}(82 \%)$ of $27 \mathbf{b}$, as a crystalline solid, (m.p. $77-78{ }^{\circ} \mathrm{C}$ ); IR (film) 3426, $2236 \mathrm{~cm}^{-1}$; ${ }^{1} \mathrm{H}$ NMR $\delta 0.89-1.01(\mathrm{~m}, 1 \mathrm{H}), 1.28-2.05(\mathrm{~m}, 9 \mathrm{H}), 2.23(\mathrm{t}, \mathrm{J}=10.3 \mathrm{~Hz}$, $1 \mathrm{H}), 2.46(\mathrm{br} \mathrm{d}, J=2.9 \mathrm{~Hz}, 1 \mathrm{H}), 3.58-3.69(\mathrm{~m}, 2 \mathrm{H}) 3.73-3.85(\mathrm{~m}, 1 \mathrm{H}) ;{ }^{13} \mathrm{C}$ NMR $\delta 22.9$, 29.5, 29.7, 32.0, 33.9, 38.7, 44.6, 44.9, 71.3, 120.5; HRMS (EI) calcd. for $\mathrm{C}_{10} \mathrm{H}_{16} \mathrm{NO}$ (M-Cl) 166.1232 , found 166.1254 .

2-Hydroxy-6-(3-chloropropyl)cyclohexanecarbonitriles (27b, 28a, 28b): Neat $\mathrm{CCl}_{4}(95 \mu \mathrm{L}$, $3.54 \mathrm{mmol})$ was added to a room temperature, $\mathrm{CH}_{2} \mathrm{Cl}_{2}$ solution $(10 \mathrm{~mL})$ containing an equal mixture, by NMR, of viii, ix, and $\mathbf{x}$ (36 mg, $0.20 \mathrm{mmol}$ ) and triphenyl phosphine (30 mg, 0.11 mmol). After $12 \mathrm{~h}$ the reaction was diluted with a mixture of ether-pentane (1: 1, $20 \mathrm{~mL})$ and then filtered through a short pad of silica gel $(2 \mathrm{~cm} \times 2 \mathrm{~cm})$. Evaporation of the solvent and purification by radial chromatography ( $1 \mathrm{~mm}$ plate, $3: 7$ EtOAc/hexanes) afforded $17 \mathrm{mg}(43 \%)$ of 27b, $9 \mathrm{mg}$ (23\%) of 28a and $13 \mathrm{mg}$ (33\%) of $\mathbf{2 8 b}$ as colorless oils. For 28a: IR (film) 3451, $2239 \mathrm{~cm}^{-1} ;{ }^{1} \mathrm{H}$ NMR $\delta 0.92-1.07(\mathrm{~m}, 1 \mathrm{H}), 1.52-2.03(\mathrm{~m}, 11 \mathrm{H}), 2.44(\mathrm{~d}, J=10.3 \mathrm{~Hz}, 1 \mathrm{H}), 3.45$ -3.65 (m, $2 \mathrm{H}), 4.24$ (br s, $1 \mathrm{H}) ;{ }^{13} \mathrm{C}$ NMR $\delta 18.8,27.9,29.6,31.6,34.0,39.6,41.7,44.7,66.4$, 120.5; HRMS (EI) calcd. for $\mathrm{C}_{10} \mathrm{H}_{16} \mathrm{ClNO} 201.0915$, found 201.0984. For 28b: IR (film) 3452, $2238 \mathrm{~cm}^{-1} ;{ }^{1} \mathrm{H}$ NMR $\delta$ 0.80-1.01 (m, 1H), $1.32-1.44(\mathrm{~m}, 1 \mathrm{H}), 1.50-2.20(\mathrm{~m}, 11 \mathrm{H}), 2.84(\mathrm{br} \mathrm{s}, 1$ H), 3.49 - 3.62 (m, $2 \mathrm{H}), 4.23$ (br s, $1 \mathrm{H}) ;{ }^{13} \mathrm{C}$ NMR $\delta 18.8,28.0,29.8,30.7,32.4$, 39.6, 44.6, 66.4, 67.1, 118.9; HRMS (EI) calcd. for $\mathrm{C}_{10} \mathrm{H}_{16} \mathrm{NO}$ (M-Cl) 166.1232, found 166.1246. 
(3aS*, 4S*, 7aS*)-4-hydroxyoctahydro-1H-indene-3a-carbonitrile (30): A $-78{ }^{\circ} \mathrm{C}$ THF

solution of $\mathrm{LiNEt}_{2}(0.12 \mathrm{mmol})$ was prepared by the addition of a hexanes solution of $\mathrm{n}-\mathrm{BuLi}$ $(0.11 \mathrm{mmol})$ to a $-78{ }^{\circ} \mathrm{C}$, THF solution $(2 \mathrm{~mL})$ of $\mathrm{Et}_{2} \mathrm{NH}(0.01 \mathrm{~mL}, 0.12 \mathrm{mmol})$. After $20 \mathrm{~min}$ a THF solution $(2 \mathrm{~mL})$ of $\mathbf{2 8 a}(20 \mathrm{mg}, 0.010 \mathrm{mmol})$ was added and, after $4 \mathrm{~h}$ the solution was allowed to warm slowly to room temperature. After $10 \mathrm{~h}$ saturated aqueous $\mathrm{NH}_{4} \mathrm{Cl}$ was added, the aqueous phase was extracted with ethyl acetate, and the combined organic layer were washed with brine, dried $\left(\mathrm{MgSO}_{4}\right)$, and concentrated. Purification of the crude product by radial chromatography (1 mm plate, 3:7 EtOAc/hexanes), $7 \mathrm{mg}(95 \%)$ of 30 as a crystalline solid product, (m.p. 69-70 ${ }^{\circ} \mathrm{C}$ ); IR (film) 3452, $2234 \mathrm{~cm}^{-1} ;{ }^{1} \mathrm{H}$ NMR $\delta 0.86-0.88(\mathrm{~m}, 1 \mathrm{H}), 1.24-$ $2.53(\mathrm{~m}, 13 \mathrm{H}), 3.46-3.48(\mathrm{~m}, 1 \mathrm{H}) ;{ }^{13} \mathrm{C} \mathrm{NMR} \delta 19.7,21.1,23.9,27.2,32.1,33.8,45.3,49.4$, 69.0, 122.7; HRMS (EI) calcd. for $\mathrm{C}_{10} \mathrm{H}_{15} \mathrm{NO}$ 165.1148, found 165.1136. Following the same procedure for pure $\mathbf{2 8 a}$ the cyclization was repeated with a mixture of $\mathbf{2 8 a}$ and $\mathbf{2 8 b}$ in a 1:1 ratio by NMR (15 mg, $0.07 \mathrm{mmol})$ : employing $\operatorname{LiNEt}_{2}(0.20 \mathrm{mmol})$, a THF solution $(3 \mathrm{~mL})$ of $\mathrm{Et}_{2} \mathrm{NH}$ $(0.03 \mathrm{~mL}, 0.20 \mathrm{mmol})$ and a THF solution $(5 \mathrm{~mL})$ of $\mathbf{2 8 a}$ and $28 \mathbf{b}$ at $-78^{\circ} \mathrm{C}$ for $4 \mathrm{~h}$, gave after purification by radial chromatography ( $1 \mathrm{~mm}$ plate, $3: 7 \mathrm{EtOAc} /$ hexanes $) 8.5 \mathrm{mg}(69 \%)$ of 30 .

(3aS*, 7aS*)-4-oxooctahydro-1H-indene-3a-carbonitrile (ix): Solid TPAP (0.5 mg, 0.03 mmol) was added in a single portion to a room temperature, $\mathrm{CH}_{2} \mathrm{Cl}_{2}$ solution $(2 \mathrm{~mL})$ of $30(5 \mathrm{mg}$, $0.03 \mathrm{mmol}), \mathrm{NMO}(6.15 \mathrm{mg}, 0.045 \mathrm{mmol})$ and powdered $4 \AA$ molecular sieves $(16 \mathrm{mg}, 500$ $\mathrm{mg} / \mathrm{mmol}$ ). After $8 \mathrm{~h}$ the greenish-black suspension was filtered through a short pad of silica, eluting with $\mathrm{CH}_{2} \mathrm{Cl}_{2}$, the filtrate was concentrated and then purified by column chromatography (10 $\mathrm{cm}$ pipette, 1:4 EtOAc/hexanes) to give $4 \mathrm{mg}(82 \%)$ of $\mathbf{i x}$ as a colorless oil; IR (film) 2228, $1727 \mathrm{~cm}^{-1} ;{ }^{1} \mathrm{H}$ NMR $\delta 1.20-2.15(\mathrm{~m}, 9 \mathrm{H}), 2.43-2.73(\mathrm{~m}, 4 \mathrm{H}) ;{ }^{13} \mathrm{C}$ NMR $\delta 21.7,23.7,25.4$, 
28.9, 32.1, 38.2, 50.5, 100.1, 120.5, 202.7; HRMS (ESI) calcd. for $\mathrm{C}_{10} \mathrm{H}_{13} \mathrm{NO} 163.0992$, found 163.0990. Following the same procedure but employing 34 afforded the same oxonitrile ix: TPAP (0.6 mg, $0.0364 \mathrm{mmol}), \mathrm{CH}_{2} \mathrm{Cl}_{2}(3 \mathrm{~mL}), 34$ (6 mg, $\left.0.0364 \mathrm{mmol}\right), \mathrm{NMO}$ (7.4 mg, 0.054 mmol) and powdered $4 \AA$ molecular sieves $(20 \mathrm{mg}, 500 \mathrm{mg} / \mathrm{mmol})$ gave, after purification by column chromatography (10 cm pipette, 1:4 EtOAc/hexanes), $5.3 \mathrm{mg}(89 \%)$ of ix.

4-Hydroxyoctahydro-1 $\mathrm{H}$-indene-3a-carbonitriles (33 and 34): From 27a: A $-78{ }^{\circ} \mathrm{C}$ THF solution of $\mathrm{LiNEt}_{2}(0.18 \mathrm{mmol})$ was prepared by the addition of a hexanes solution of $\mathrm{n}-\mathrm{BuLi}$ (0.07 mL, $0.17 \mathrm{mmol})$ to a $-78{ }^{\circ} \mathrm{C}$, THF solution $(2 \mathrm{~mL})$ of $\mathrm{Et}_{2} \mathrm{NH}(0.02 \mathrm{~mL}, 0.18 \mathrm{mmol})$. After 20 min a THF solution $(2 \mathrm{~mL})$ of $27 \mathrm{a}(20 \mathrm{mg}, 0.010 \mathrm{mmol})$ was added and, after $4 \mathrm{~h}$ the solution was allowed to warm slowly to room temperature. After $10 \mathrm{~h}$ saturated aqueous $\mathrm{NH}_{4} \mathrm{Cl}$ was added, the aqueous phase was extracted with ethyl acetate, and the combined organic layer were washed with brine, dried $\left(\mathrm{MgSO}_{4}\right)$, and concentrated. Purification of the crude product by radial chromatography ( $1 \mathrm{~mm}$ plate, 1:1 EtOAc/hexanes) and afforded, $5 \mathrm{mg}(45 \%)$ of (3a $\boldsymbol{R}^{*}, \mathbf{4} \boldsymbol{R}^{*}$, 7aS*)-4-hydroxyoctahydro-1 $H$-indene-3a-carbonitrile (33) and $4 \mathrm{mg}(36 \%)$ of (3aS*, $4 \boldsymbol{R}^{*}$, 7aS*)-4-hydroxyoctahydro-1H-indene-3a-carbonitrile (34) as colorless oils. For 33: IR (film) 3453, $2232 \mathrm{~cm}^{-1}$; ${ }^{1} \mathrm{H}$ NMR $\delta 1.21-2.01(\mathrm{~m}, 13 \mathrm{H}), 2.32-2.43(\mathrm{~m}, 1 \mathrm{H}), 3.42(\mathrm{dd}, J=11.0,3.7 \mathrm{~Hz}$, $1 \mathrm{H}) ;{ }^{13} \mathrm{C}$ NMR $\delta 20.3,24.5,26.6,28.2,32.7,34.6,48.0,54.6,75.7,120.9$; HRMS (EI) calcd. for $\mathrm{C}_{10} \mathrm{H}_{15} \mathrm{NO}$ 165.1148, found 165.1136. For 34: IR (film) 3413, $2231 \mathrm{~cm}^{-1} ;{ }^{1} \mathrm{H}$ NMR $\delta 0.97-2.27$ (m, $14 \mathrm{H}), 4.40-4.11(\mathrm{~m}, 1 \mathrm{H}) ;{ }^{13} \mathrm{C}$ NMR $\delta 19.9,22.5,27.0,28.8,29.7,30.3,44.9,50.5,72.3$, 125.5; HRMS (EI) calcd. for $\mathrm{C}_{10} \mathrm{H}_{15} \mathrm{NO} 165.1148$, found 165.1136. Following the same procedure as for $27 \mathrm{a}$ with $\mathrm{LiNEt}_{2}(0.05 \mathrm{mmol})$, a THF solution $(2 \mathrm{~mL})$ of $\mathrm{Et}_{2} \mathrm{NH}(6 \mu \mathrm{L}, 0.054 \mathrm{mmol})$ and a THF solution $(2 \mathrm{~mL})$ of $\mathbf{2 7 b}$ : $(4 \mathrm{mg}, 0.02 \mathrm{mmol})$ at $-78^{\circ} \mathrm{C}$ for $4 \mathrm{~h}$, gave after purification by radial 
chromatography ( $1 \mathrm{~mm}$ plate, $3: 7 \mathrm{EtOAc} /$ hexanes) $1.5 \mathrm{mg}(45 \%)$ of 33 and $1.4 \mathrm{mg}$ (42\%) of 34 as colorless oils. Neat HMPA $(0.2 \mathrm{~mL})$ was added to a $-78{ }^{\circ} \mathrm{C}$, THF solution of $\mathrm{LiNEt}_{2}$ (10 equiv) followed by a THF solution ( $1 \mathrm{~mL})$ of 27 a (1 equiv) and then the solution was allowed to warm slowly to room temperature. After $16 \mathrm{~h}$ saturated aqueous $\mathrm{NH}_{4} \mathrm{Cl}$ was added, the aqueous phase was extracted with ethyl acetate, and the combined organic layer were washed with brine, dried $\left(\mathrm{MgSO}_{4}\right)$, and concentrated. Purification of the crude product by radial chromatography gave 24 $\%$ of $\mathbf{3 3}$ as an oil and $49 \%$ of $\mathbf{3 4}$ as an oil. Employing the same procedure with 27b afforded 20 $\%$ of 33 as an oil and $41 \%$ of 34 as an oil.

(3aR*, 7aS*)-4-oxooctahydro-1H-indene-3a-carbonitrile $(\mathrm{x})$ : Following the same procedure as for xi TPAP (0.4 mg, $0.021 \mathrm{mmol}), \mathrm{CH}_{2} \mathrm{Cl}_{2}(2 \mathrm{~mL}), 33(3.5 \mathrm{mg}, 0.021 \mathrm{mmol}), \mathrm{NMO}(5 \mathrm{mg}$, $0.032 \mathrm{mmol}$ ) and powdered $4 \AA$ molecular sieves $(15 \mathrm{mg}, 500 \mathrm{mg} / \mathrm{mmol})$ gave, after purification by column chromatography ( $10 \mathrm{~cm}$ pipette, $1: 4 \mathrm{EtOAc} / \mathrm{hexanes}), 3 \mathrm{mg}(87 \%)$ of $\mathbf{x}$ as a colorless oil; IR (film) 2226, $1726 \mathrm{~cm}^{-1} ;{ }^{1} \mathrm{H}$ NMR $\delta 0.78-0.94$ (m, $\left.2 \mathrm{H}\right), 1.17-2.25$ (m, $\left.3 \mathrm{H}\right), 2.43$ (dd, $J=10.3,4.4 \mathrm{~Hz}, 1 \mathrm{H}) 2.86(\mathrm{dt}, J=7.4,5.9 \mathrm{~Hz}, 1 \mathrm{H}) ;{ }^{13} \mathrm{C}$ NMR $\delta 20.1,26.9,27.6,28.7,28.9,29.6$, $38.7,54.0,123.2,202.2$.

2-Oxocyclopentanecarbonitrile (xi): Solid $t$-BuOK (1 equiv) was added to a room temperature, THF solution of adiponitrile ( 1 equiv). After $1 \mathrm{~h}$ aqueous $\mathrm{H}_{2} \mathrm{SO}_{4}(1 \mathrm{M})$ was added and the mixture allowed to stir at room temperature. After $16 \mathrm{~h}$ saturated aqueous $\mathrm{NH}_{4} \mathrm{Cl}$ was added, the aqueous phase was extracted with ethyl acetate, and the combined organic layers were washed with brine, dried $\left(\mathrm{MgSO}_{4}\right)$, and concentrated. Purification of the crude product by radial chromatography gave $2.5 \mathrm{~g}(83 \%)$ of the oxonitrile xi spectrally identical to material previously isolated. ${ }^{3}$ 


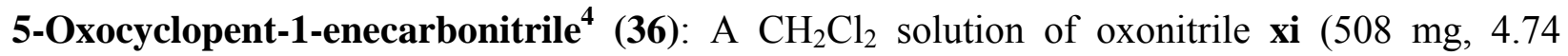
mmole) was added to a $0{ }^{\circ} \mathrm{C}, \mathrm{CH}_{2} \mathrm{Cl}_{2}$ solution of pyridine (1.2 equiv) and phenylselenyl chloride (1.0 equiv.). After 15 min. the solution was extracted with water and then aqueous $\mathrm{H}_{2} \mathrm{O}_{2}(30 \%)$ was added to the crude selenide with vigorous stirring. After $15 \mathrm{~min}$. saturated aqueous $\mathrm{NH}_{4} \mathrm{Cl}$ was added, the aqueous phase was extracted with ethyl acetate, and the combined organic layers were washed with brine, dried $\left(\mathrm{MgSO}_{4}\right)$, and concentrated. Purification of the crude product by rapid elution from a short $(2.5 \times 2.5 \mathrm{~cm})$ column of silica gel $(230-400 \mathrm{mesh})$ gave $253 \mathrm{mg}$ $(50 \%)$ of oxonitrile xiv spectrally identical to material previously isolated ${ }^{4 b}$

$\left(1 R^{*}, 2 S^{*}, 5 S^{*}\right)-2-(4-c h l o r o b u t y l)-5-h y d r o x y c y c l o p e n t a n e c a r b o n i t r i l e ~(37 a) ~\left(1 S^{*}, 2 S^{*}, 5 S^{*}\right)-$ 2-(4-chlorobutyl)-5-hydroxycyclopentanecarbonitrile (37b) and (1S*, 2S*, 5S*)-2-(4chlorobutyl)-5-hydroxycyclopentanecarbonitrile (38). A $\quad$ THF $\quad$ solution of 4chlorobutylmagnesium bromide ${ }^{5}$ was prepared by the addition of a few drops of 1-bromo-4chlorobutane to magnesium metal (2.1 equiv.) at room temperature. The solution was sonicated until cloudy, cooled to $0{ }^{\circ} \mathrm{C}$, and then neat 1-bromo-4-chlorobutane (2 equiv.) was slowly added. After $2 \mathrm{~h}$ the solution was briefly warmed to room temperature and was then added to a $0{ }^{\circ} \mathrm{C}$, THF solution of $36(140 \mathrm{mg}, 1.30 \mathrm{mmol})$. After $2 \mathrm{~h}$ the resultant mixture was quenched by the addition of saturated, aqueous $\mathrm{NH}_{4} \mathrm{Cl}$, extracted with EtOAc, dried $\left(\mathrm{MgSO}_{4}\right)$, and concentrated to afford $260 \mathrm{mg}$ of the crude ketone as an oil. Incremental portions of solid $\mathrm{NaBH}_{4}$ (excess) were added over 20 min to a room temperature, methanol solution of the crude ketone with vigorous stirring. After $1 \mathrm{~h}$ the solution was concentrated and then saturated aqueous $\mathrm{NH}_{4} \mathrm{Cl}$ and EtOAc were added, the aqueous phase was extracted with ethyl acetate, and then the organic extracts 
were combined and washed successively with $10 \%$ aqueous $\mathrm{HCl}$ and brine, dried $\left(\mathrm{MgSO}_{4}\right)$ and concentrated. The crude product was purified by radial chromatography to give $3 \mathrm{mg}(5 \%)$ of 37a as an oil, $10 \mathrm{mg}(16 \%)$ of $\mathbf{3 7 b}$ as an oil, and $14 \mathrm{mg}(23 \%)$ of 38 as an oil. For 37a: IR (film) $3441,2241 \mathrm{~cm}^{-1} ;{ }^{1} \mathrm{H}$ NMR $\delta: 1.16-1.86(\mathrm{~m}, 8 \mathrm{H}), 2.08-2.16(\mathrm{~m}, 2 \mathrm{H}), 2.29(\mathrm{~d}, J=3.1 \mathrm{~Hz}, 1 \mathrm{H})$, $2.35(\mathrm{dd}, J=10.7,4.8 \mathrm{~Hz}, 1 \mathrm{H}), 2.39-2.47(\mathrm{~m}, 1 \mathrm{H}), 3.55(\mathrm{t}, J=6.6 \mathrm{~Hz}, 2 \mathrm{H}), 4.45(\mathrm{~s}, 1 \mathrm{H}) ;{ }^{13} \mathrm{C}$ NMR $\delta:$ 24.9, 28.8, 32.3, 33.5, 34.2, 43.5, 44.1, 44.7, 77.4, 121.6. For 37b: IR (film) 3450, 2240 $\mathrm{cm}^{-1} ;{ }^{1} \mathrm{H}$ NMR $\delta: \quad 1.38-1.60(\mathrm{~m}, 3 \mathrm{H}), 1.62-1.74(\mathrm{~m}, 2 \mathrm{H}), 1.76-1.83(\mathrm{~m}, 2 \mathrm{H}), 1.89-1.96(\mathrm{~m}, 2 \mathrm{H})$, 1.98-2.07 (m, 2H), 2.08-2.18 (m, 1H), $2.33(\mathrm{dd}, J=6.8,3.9 \mathrm{~Hz}, 1 \mathrm{H}), 3.55(\mathrm{t}, J=6.8 \mathrm{~Hz}, 2 \mathrm{H})$, 4.46 (s, $1 \mathrm{H}) ;{ }^{13} \mathrm{C}$ NMR $\delta: 24.9,28.8,32.3,33.4,34.2,43.5,44.1,44.7,76.7,121.6$; HRMS (ESI) calcd. for $\mathrm{C}_{10} \mathrm{H}_{17} \mathrm{CINO}(\mathrm{M}+\mathrm{H})$ 202.0995, found 202.1020. For 38: IR (film) 3439, $2250 \mathrm{~cm}^{-1} ;{ }^{1} \mathrm{H}$ NMR $\delta: ~ 1.46-1.62(m, 2 H), 1.62-1.75(\mathrm{~m}, 3 \mathrm{H}), 1.78-1.95(\mathrm{~m}, 3 \mathrm{H}), 1.96-2.04(\mathrm{~m}, 2 \mathrm{H}), 2.08-2.18$ (m, 2H), $3.12(\mathrm{t}, J=6.8 \mathrm{~Hz}, 1 \mathrm{H}), 3.57(\mathrm{t}, J=7.8 \mathrm{~Hz}, 2 \mathrm{H}), 4.40(\mathrm{~s}, 1 \mathrm{H}) ;{ }^{13} \mathrm{C}$ NMR $\delta: 25.1,29.0$, 32.4, 33.3, 33.7, 42.1, 43.5, 44.7, 73.1, 120.0; HRMS (nano-ESI) calcd. for $\mathrm{C}_{10} \mathrm{H}_{16} \mathrm{ClNO}$ 201.0920, found 201.0956.

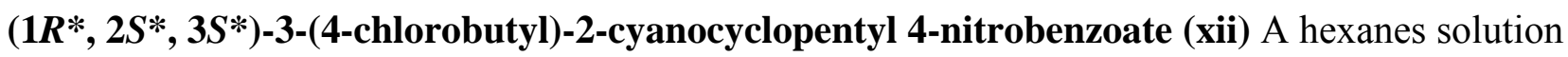
of butyllithium (1.1 equiv., $1.45 \mathrm{M}$ in hexanes) was added to a cold $\left(-78^{\circ} \mathrm{C}\right)$, THF solution $(1 \mathrm{~mL})$ of 38 (16 mg, $0.079 \mathrm{mmol}$ ), followed after $10 \mathrm{~min}$, by neat $p$-nitrobenzoyl chloride (1.5 equiv.). The resulting solution was allowed to warm to $\mathrm{rt}$ and stirred for $1 \mathrm{~h}$ before the addition of water. Extraction with EtOAc, drying $\left(\mathrm{MgSO}_{4}\right)$, concentration and radial chromatography provided 13 mg $(46 \%)$ of the $p$-nitrobenzoate xii as a crystalline solid (m.p. $72-76{ }^{\circ} \mathrm{C}$ ) whose structure was solved by x-ray diffraction (CCDC\# 626356): IR (film) 2243, 1732, $1529 \mathrm{~cm}^{-1} ;{ }^{1} \mathrm{H}$ NMR $\delta: 1.30-$ $1.65(\mathrm{~m}, 3 \mathrm{H}), 1.69-1.87(\mathrm{~m}, 4 \mathrm{H}), 1.93-2.03(\mathrm{~m}, 1 \mathrm{H}), 2.15-2.23(\mathrm{~m}, 1 \mathrm{H}), 2.30-2.38(\mathrm{~m}, 1 \mathrm{H}), 2.42-$ 
$2.57(\mathrm{~m}, 1 \mathrm{H}), 2.66-2.75(\mathrm{~m}, 1 \mathrm{H}), 3.56-3.61(\mathrm{~m}, 2 \mathrm{H}), 5.55-5.59(\mathrm{~m}, 1 \mathrm{H}), 8.20-8.35(\mathrm{~m}, 4 \mathrm{H}) ;{ }^{13} \mathrm{C}$

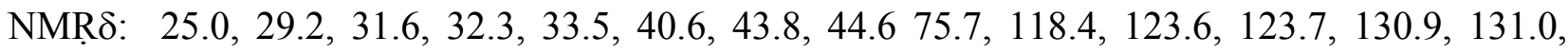
$134.9,150.7,163.8$.

$\left(3 R^{*}, 3 a S^{*}, 7 a S^{*}\right)-3-h y d r o x y o c t a h y d r o-1 H-i n d e n e-3 a-c a r b o n i t r i l e ~(40)$ A $-78{ }^{\circ} \mathrm{C}$ THF solution of $\mathrm{LiNEt}_{2}$ ( 3 equiv.) was prepared by the addition of a hexanes solution of BuLi ( 3 equiv) to a -78 ${ }^{\circ} \mathrm{C}$, THF solution $(1 \mathrm{~mL})$ of $\mathrm{Et}_{2} \mathrm{NH}$ (3.2 equiv.). After 20 min a THF solution $(1 \mathrm{~mL})$ of 38 (47 $\mathrm{mg}, 0.23 \mathrm{mmol}$ ) was added and the solution was allowed to warm slowly to room temperature. After $8 \mathrm{~h}$ saturated aqueous $\mathrm{NH}_{4} \mathrm{Cl}$ was added, the aqueous phase was extracted with ethyl acetate, and the combined organic layers were washed with brine, dried $\left(\mathrm{MgSO}_{4}\right)$, and concentrated. Purification of the crude product by radial chromatography afforded $28.9 \mathrm{mg}(78 \%)$ of 40 as an oil: IR (film) 3453, $2236 \mathrm{~cm}^{-1} ;{ }^{1} \mathrm{H}$ NMR $\delta$ 1.24-1.35 (m, 2H), 1.40-1.49 (m, 2H), 1.51-1.85 (m, 6H), 1.88-1.97 (m, 1H), 2.17-2.30 (m, 2H), 2.60-2.70 (m, 1H), 4.08-4.15 (m, $1 \mathrm{H})$; ${ }^{13} \mathrm{C}$ NMR $\delta$ 20.2, 22.2, 24.5, 24.9, 28.0, 31.4, 40.1, 49.2, 78.0, 122.7; HRMS (EI) calcd. for $\mathrm{C}_{10} \mathrm{H}_{15} \mathrm{NO} 165.1148$, found 165.1144 .

$\left(1 R^{*}, 3 a S^{*}, 7 \mathrm{a} S^{*}\right)-7 \mathrm{a}-\mathrm{cyanooctahydro-1H-inden-1-yl} \mathrm{4-nitrobenzoate} \mathrm{(xiii):} \mathrm{A} \mathrm{hexanes}$ solution of butyllithium (1.1 equiv., $1.45 \mathrm{M}$ in hexanes) was added to a cold $\left(-78{ }^{\circ} \mathrm{C}\right)$, THF solution $(1 \mathrm{~mL})$ of $\mathbf{4 0}$ (1 equiv.), followed after $10 \mathrm{~min}$, by neat $p$-nitrobenzoyl chloride $(1.5$ equiv.). The resulting solution was allowed to warm to $\mathrm{rt}$ and stirred for $1 \mathrm{~h}$ before the addition of water. Extraction with EtOAc, drying $\left(\mathrm{MgSO}_{4}\right)$, concentration and radial chromatography provided the $p$-nitrobenzoate xiii $(84 \%)$ as a crystalline solid whose structure was solved by $\mathrm{x}$-ray diffraction (CCDC\# 626357): IR (film) 2238, 1724, $1523 \mathrm{~cm}^{-1} ;{ }^{1} \mathrm{H}$ NMR $\delta: 0.80-0.95(\mathrm{~m}, 1 \mathrm{H})$, 
1.40-1.95 (m, 4H), 2.42-2.49 (m, 1H), 2.68-2.74 (m, 1H), 5.28-5.32 (m, 1H), 8.27-8.32 (m, 4H);

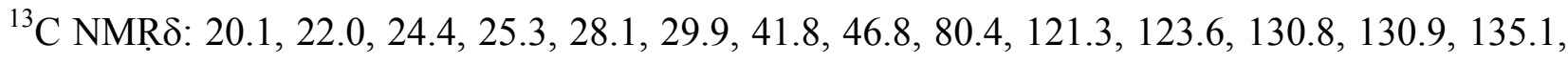
163.8 .

(3aS*, 7a $\left.S^{*}\right)$-3-oxooctahydro-1H-indene-3a-carbonitrile (xiv) An acetone solution (1 mL) of 40 (4 mg, $24.2 \mu \mathrm{mol}$ ) was added to an aqueous solution of Jones reagent and after $1 \mathrm{~h}$ the reaction was concentrated and purified by elution from a short $(2.5 \times 0.5 \mathrm{~cm})$ column of silica gel $(230-400$ mesh) to afford $4 \mathrm{mg}(100 \%)$ of xiv as an oil as an oil: IR (film) $2239,1750 \mathrm{~cm}^{-1} ;{ }^{1} \mathrm{H}$ NMR $\delta$ 1.42-2.03 (m, 10H), 2.40-2.63 (m, 3H); ${ }^{13} \mathrm{C}$ NMR $\delta$ 20.4, 21.8, 22.9, 24.7, 26.8, 35.3, 40.4, 48.7, 119.4, 208.9. An analogous oxidation of $\mathbf{4 4}$ afforded (75\%) of xvi exhibiting identical spectra.

$\left(3 S^{*}, 3 a R^{*}, 7 \mathrm{a} S^{*}\right)$-3-hydroxyoctahydro-1H-indene-3a-carbonitrile (43) (3S*, 3aS*, 7a $\left.S^{*}\right)-3-$ hydroxyoctahydro-1H-indene-3a-carbonitrile (44). A $-78^{\circ} \mathrm{C}$ THF solution of $\mathrm{LiNEt}_{2}$ (3 equiv.) was prepared by the addition of a hexanes solution of $\mathrm{BuLi}$ ( 3 equiv.) to a $-78^{\circ} \mathrm{C}$, THF solution (1 $\mathrm{mL}$ ) of $\mathrm{Et}_{2} \mathrm{NH}$ (3.2 equiv.). After $20 \mathrm{~min}$ a THF solution $(1 \mathrm{~mL})$ of $37 \mathbf{b}(16 \mathrm{mg}, 0.079 \mathrm{mmol})$ was added and the solution was allowed to warm slowly to room temperature. After $8 \mathrm{~h}$ saturated aqueous $\mathrm{NH}_{4} \mathrm{Cl}$ was added, the aqueous phase was extracted with ethyl acetate, and the combined organic layers were washed with brine, dried $\left(\mathrm{MgSO}_{4}\right)$, and concentrated. Purification of the crude product by radial chromatography afforded $3.4 \mathrm{mg}(26 \%)$ of 43 as an oil and $2.2 \mathrm{mg}(17 \%)$ of 44 as an oil. For 43: IR (film) 3440, $2236 \mathrm{~cm}^{-1}$; ${ }^{1} \mathrm{H}$ NMR $\delta 1.16-1.30(\mathrm{~m}, 3 \mathrm{H}), 1.42-1.56(\mathrm{~m}, 3 \mathrm{H})$, $1.58-1.90(\mathrm{~m}, 6 \mathrm{H}), 2.20-2.28(\mathrm{~m}, 1 \mathrm{H}), 2.32(\mathrm{~d}, J=12.6 \mathrm{~Hz}, 1 \mathrm{H}), 3.89(\mathrm{q}, J=7.8 \mathrm{~Hz}, 1 \mathrm{H}) ;{ }^{13} \mathrm{C}$ NMR $\delta 22.8,25.2,26.4,28.2,30.5,32.6,45.0,53.2,78.9,120.1 ;$ MS m/e $166(\mathrm{M}+\mathrm{H})$. For 44: IR (film) 3461, $2233 \mathrm{~cm}^{-1}$; ${ }^{1} \mathrm{H}$ NMR $\delta$ 1.38-1.93 (m, 11H), 2.16-2.26 (m, 2H), 2.34-2.42 (m, 1H), 
$4.50(\mathrm{t}, J=8.7 \mathrm{~Hz}, 1 \mathrm{H}) ;{ }^{13} \mathrm{C}$ NMR $\delta 19.8,22.0,23.0,23.7,24.5,29.6,40.5,45.2,79.0,124.4 ; \mathrm{MS}$ $\mathrm{m} / \mathrm{e} 166(\mathrm{M}+\mathrm{H})$. Repeating the procedure for the conversion of $\mathbf{3 7 b}$ into 43 but employing a THF solution containing HMPA (10\% by volume) with BuLi (10 equiv.), $\mathrm{Et}_{2} \mathrm{NH}$ (10.1 equiv), 37b (32 mg, $0.16 \mathrm{mmol})$, THF (2 mL), and HMPA $(0.2 \mathrm{~mL})$ afforded $14.7 \mathrm{mg}(57 \%)$ of 43 as an oil. Repeating the procedure for the conversion of 37b into 43 but employing 37a afforded 43 (63\%) as an oil.

(3aR*, 7a $\left.S^{*}\right)$-3-oxooctahydro-1H-indene-3a-carbonitrile (xv) An acetone solution (1 mL) of 43 (7 mg, $42.3 \mu \mathrm{mol}$ ) was added to an aqueous solution of Jones reagent and after $1 \mathrm{~h}$ the reaction was concentrated and purified by elution from a short $(2.5 \times 0.5 \mathrm{~cm})$ column of silica gel $(230-400$ mesh) to afford $7 \mathrm{mg}(100 \%)$ of $\mathbf{x v}$ as an oil: IR (film) 2227, $1752 \mathrm{~cm}^{-1} ;{ }^{1} \mathrm{H}$ NMR $\delta 1.20-1.38(\mathrm{~m}$, 3H), 1.58-1.78 (m, 3H), 1.85-1.99 (m, 3H), 2.09-2.14 (m, 1H), 2.22-2.30 (m, 2H), $2.64(\mathrm{dd}, J=$ $22,10 \mathrm{~Hz}, 1 \mathrm{H}) ;{ }^{13} \mathrm{C}$ NMR $\delta 22.3,25.1,25.4,28.0,29.3,35.6,46.9,52.4,116.4,207.3$. 


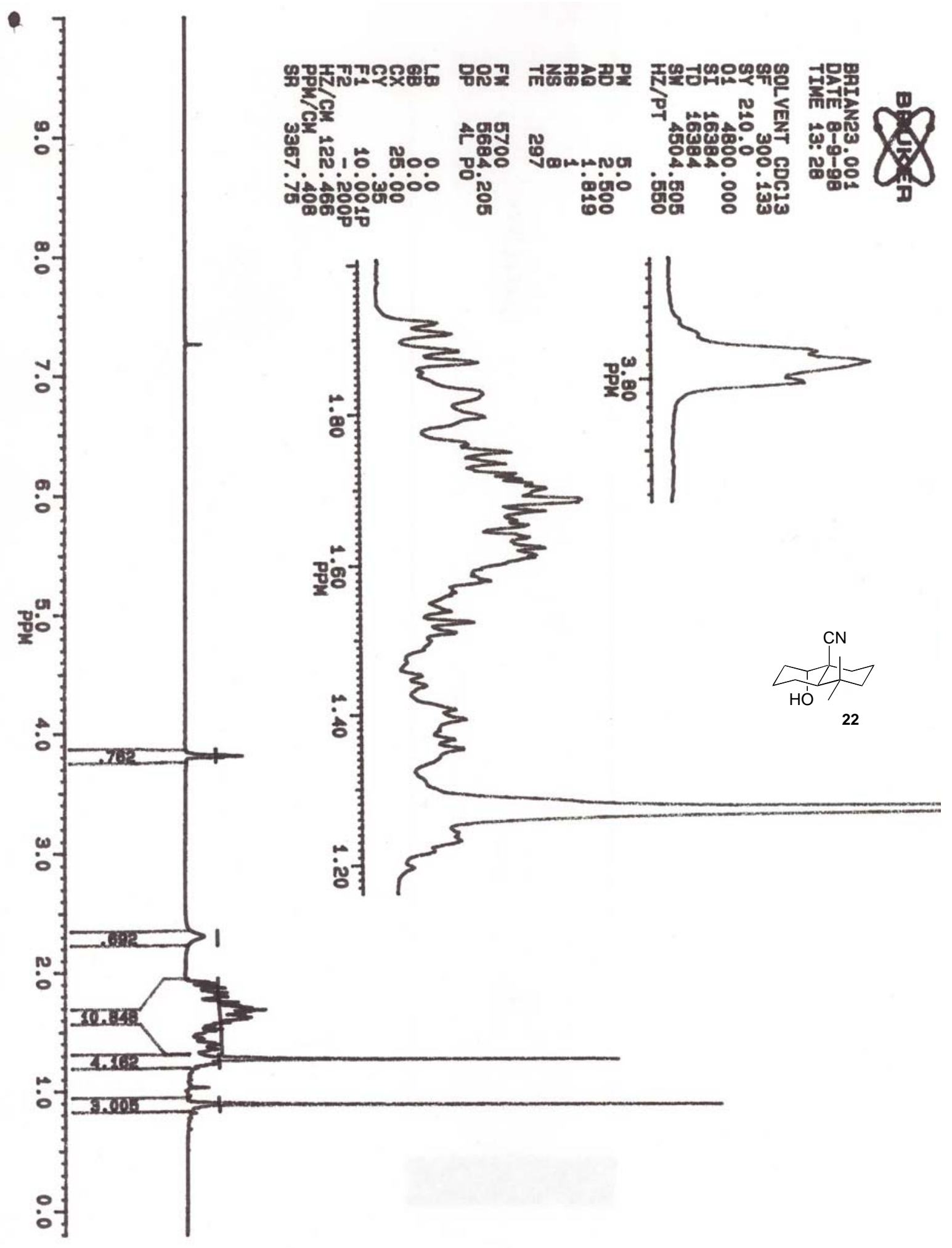




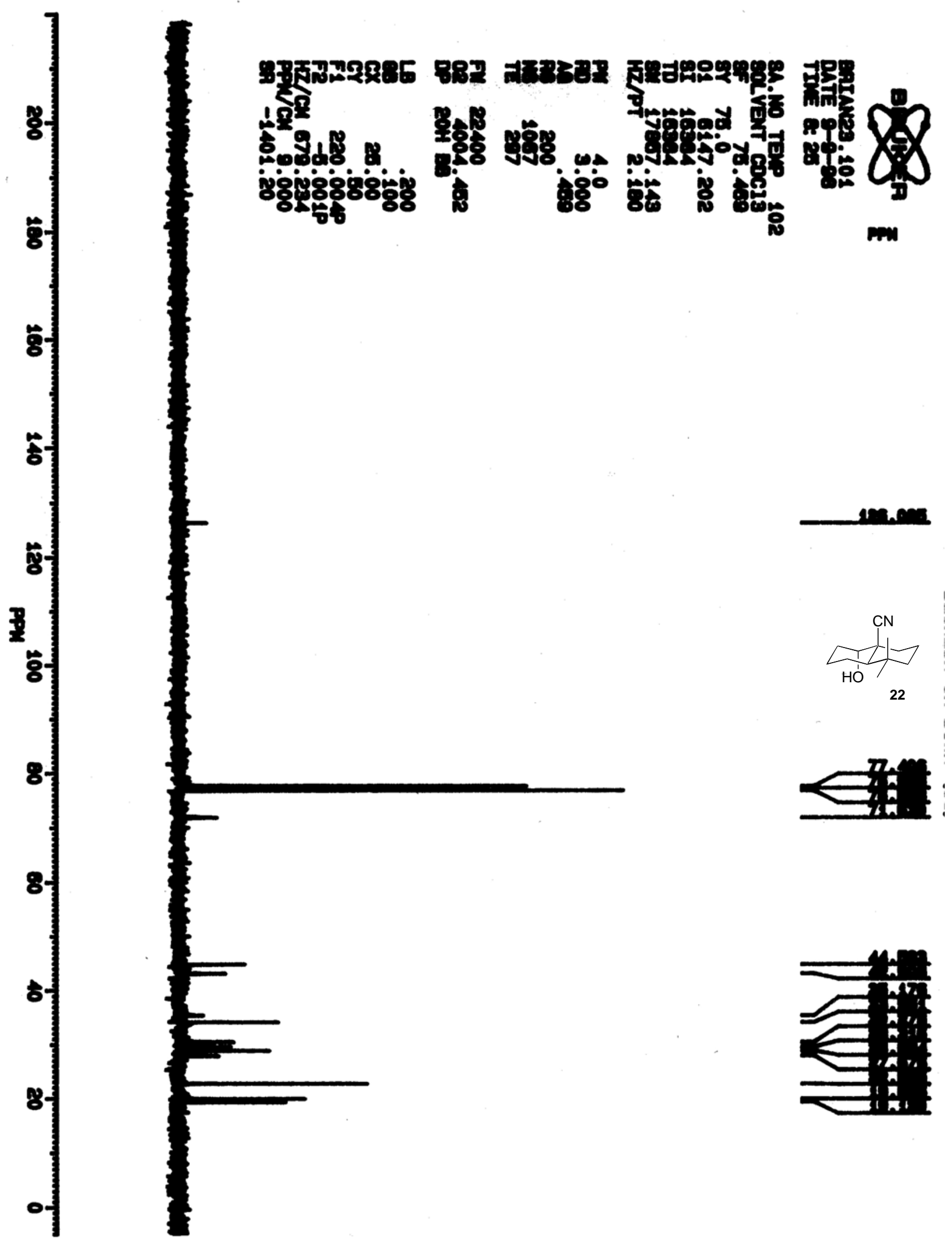




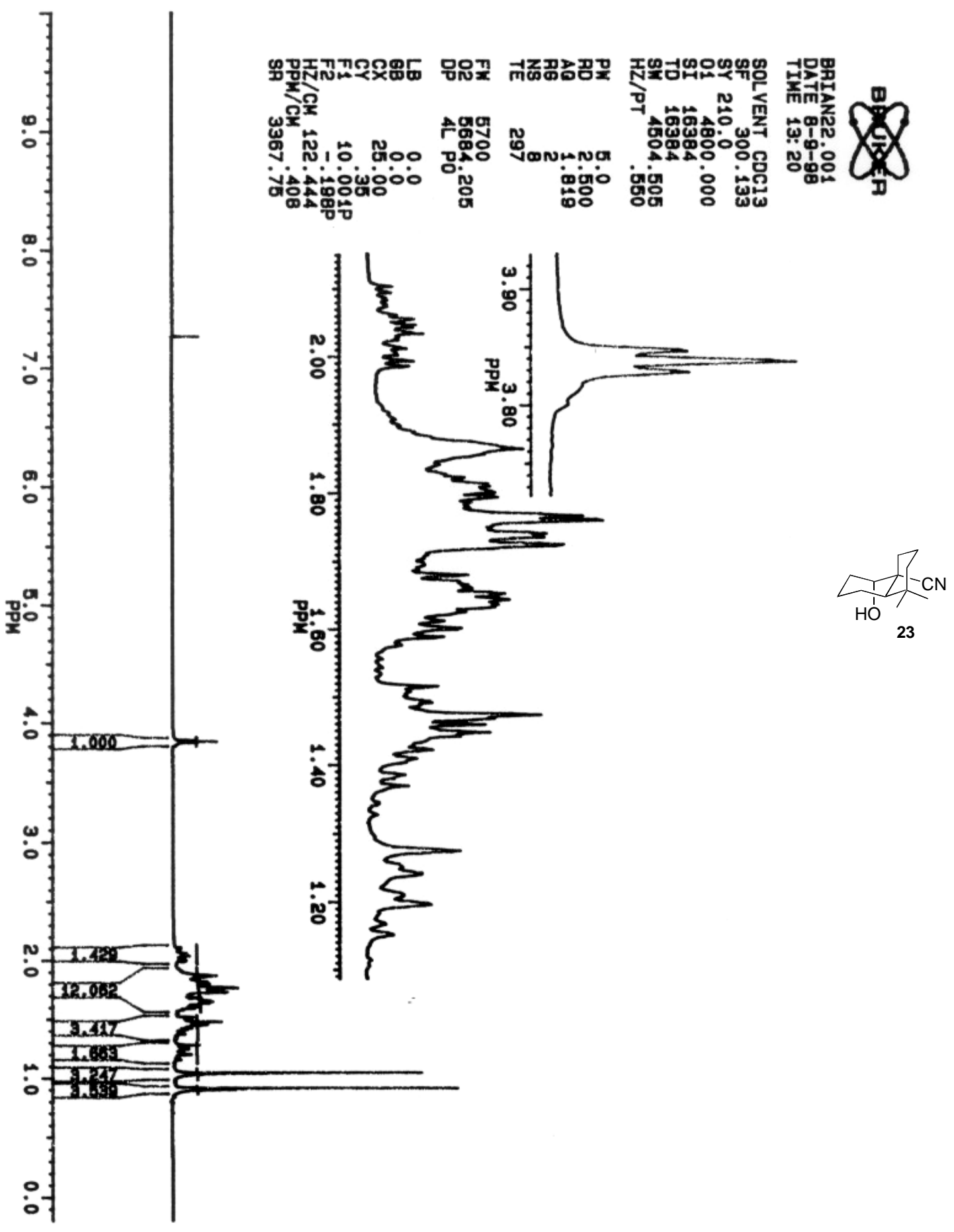




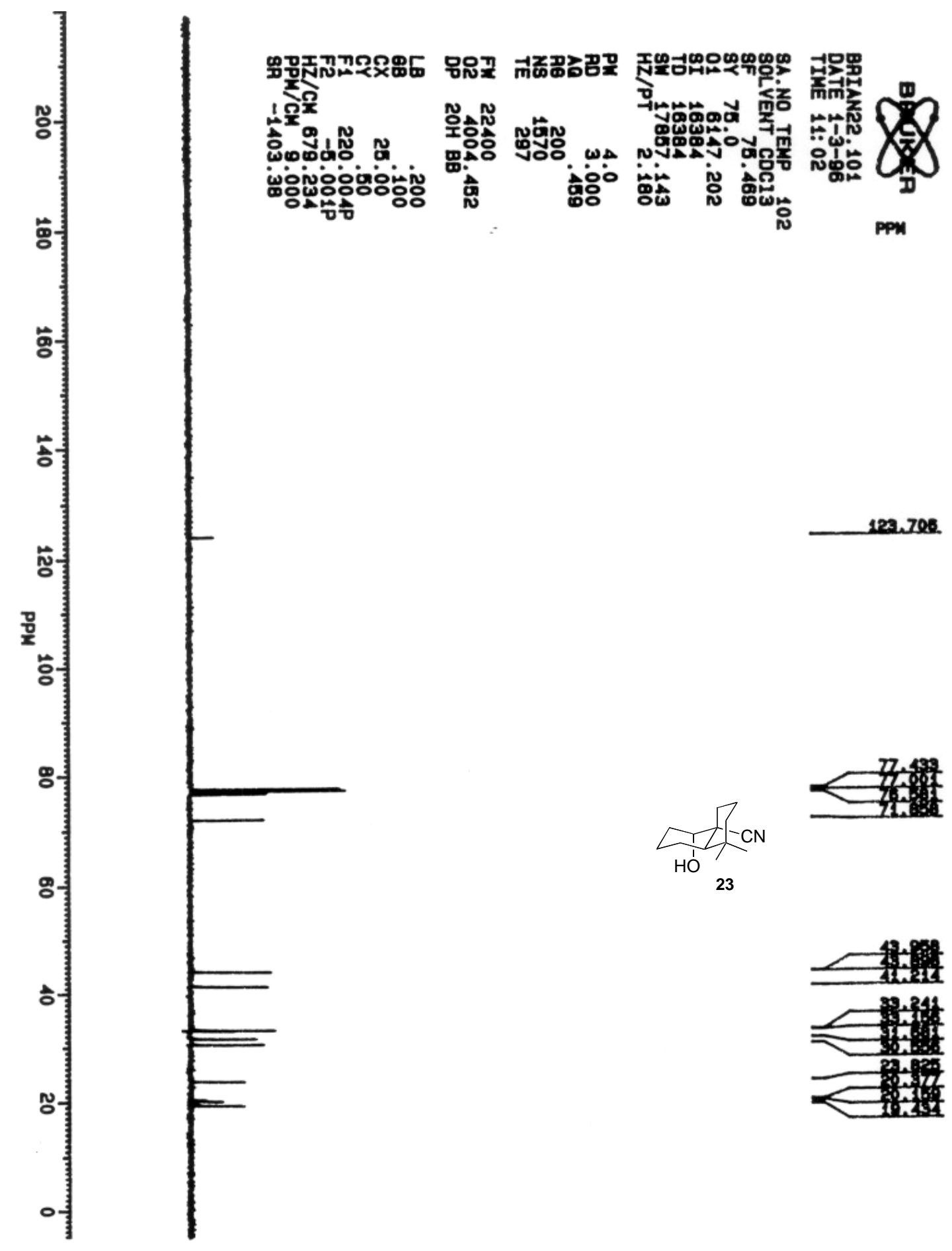




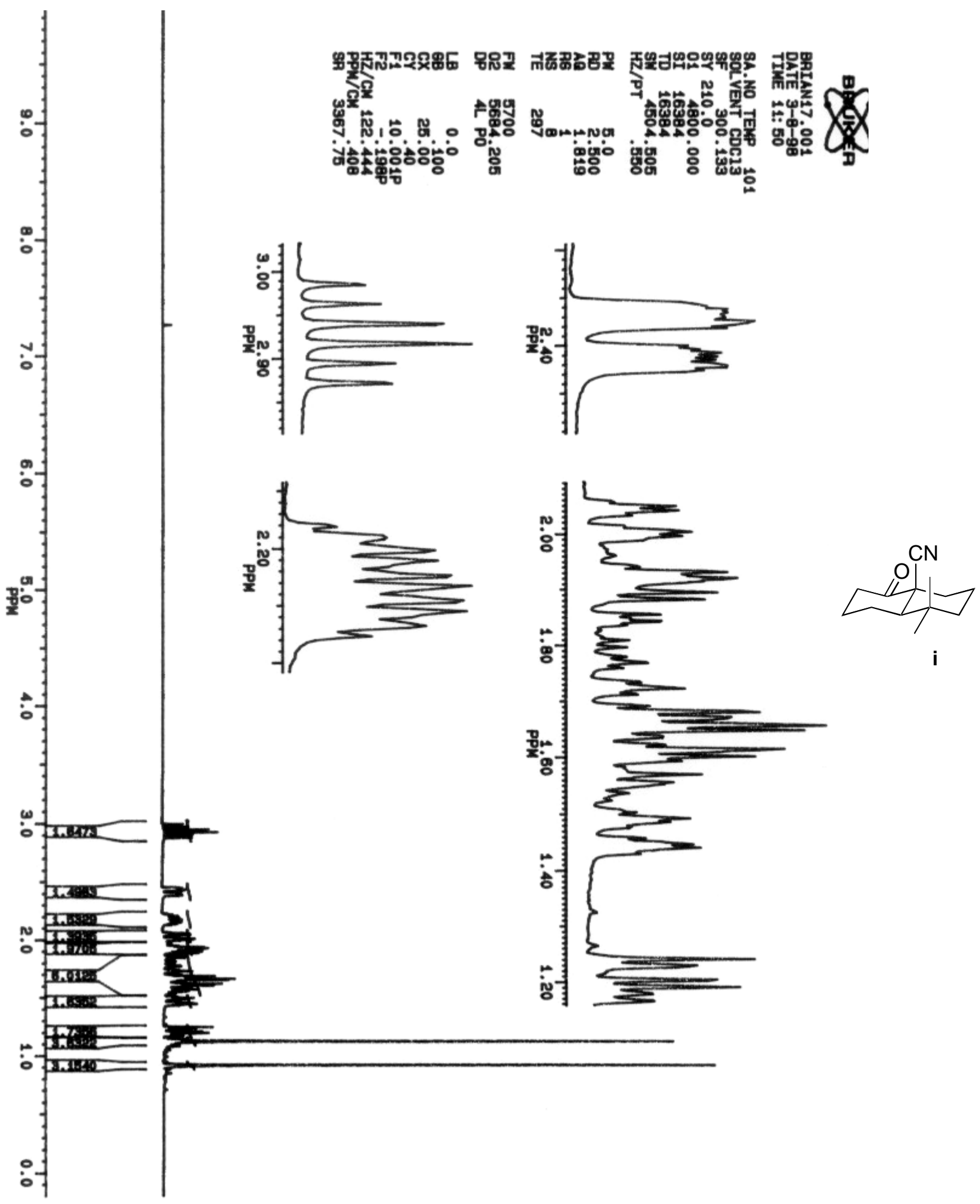




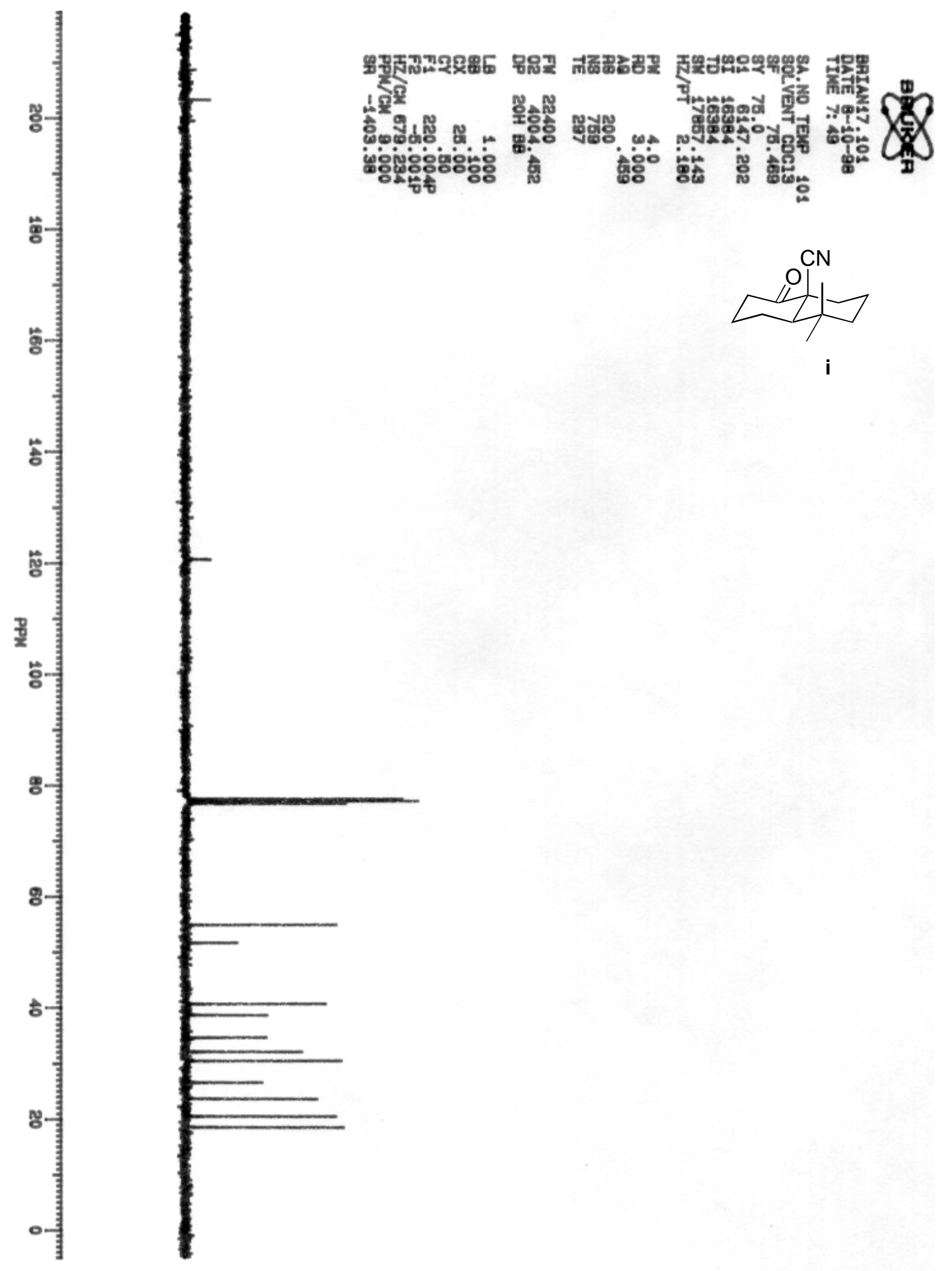




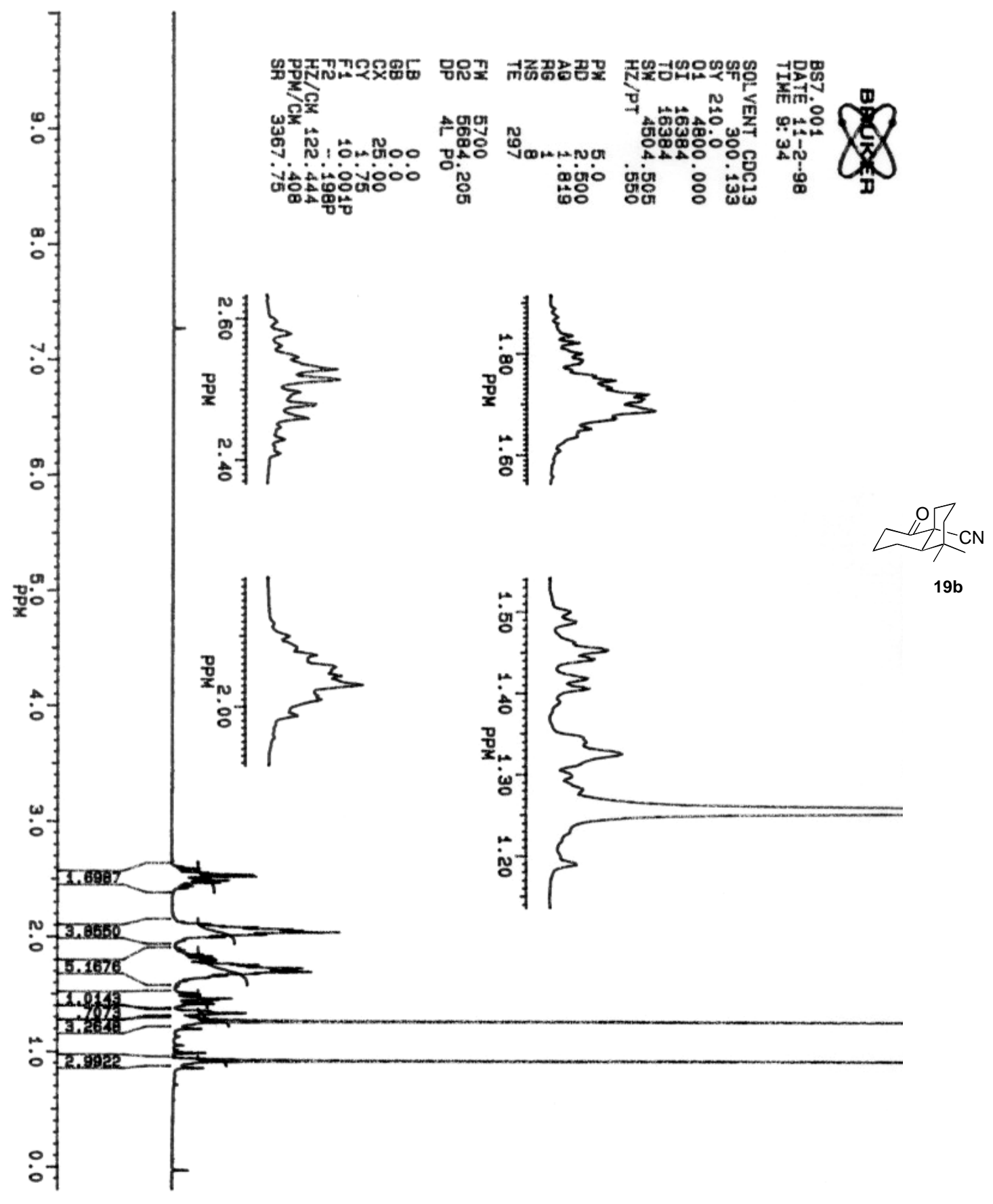




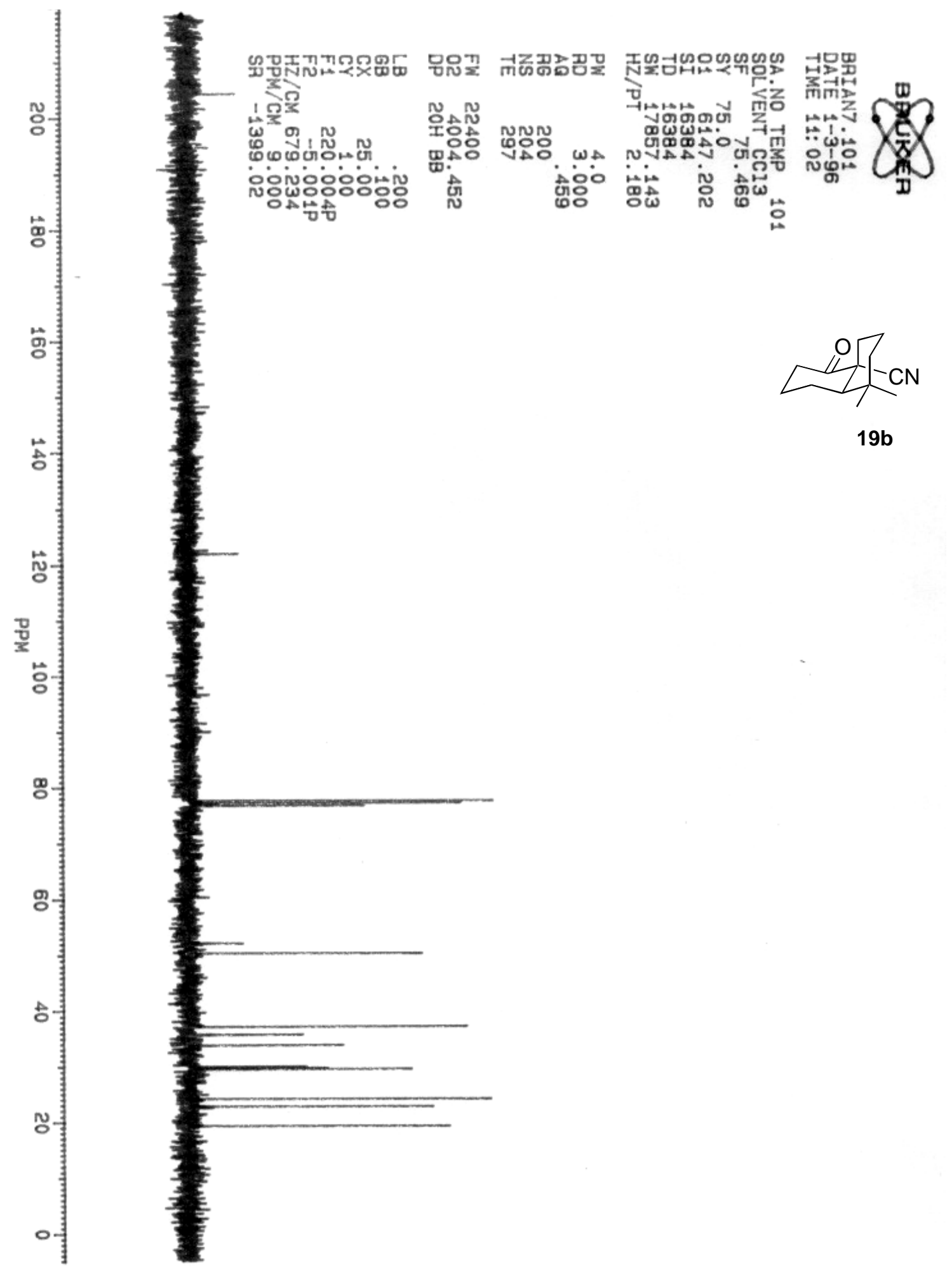




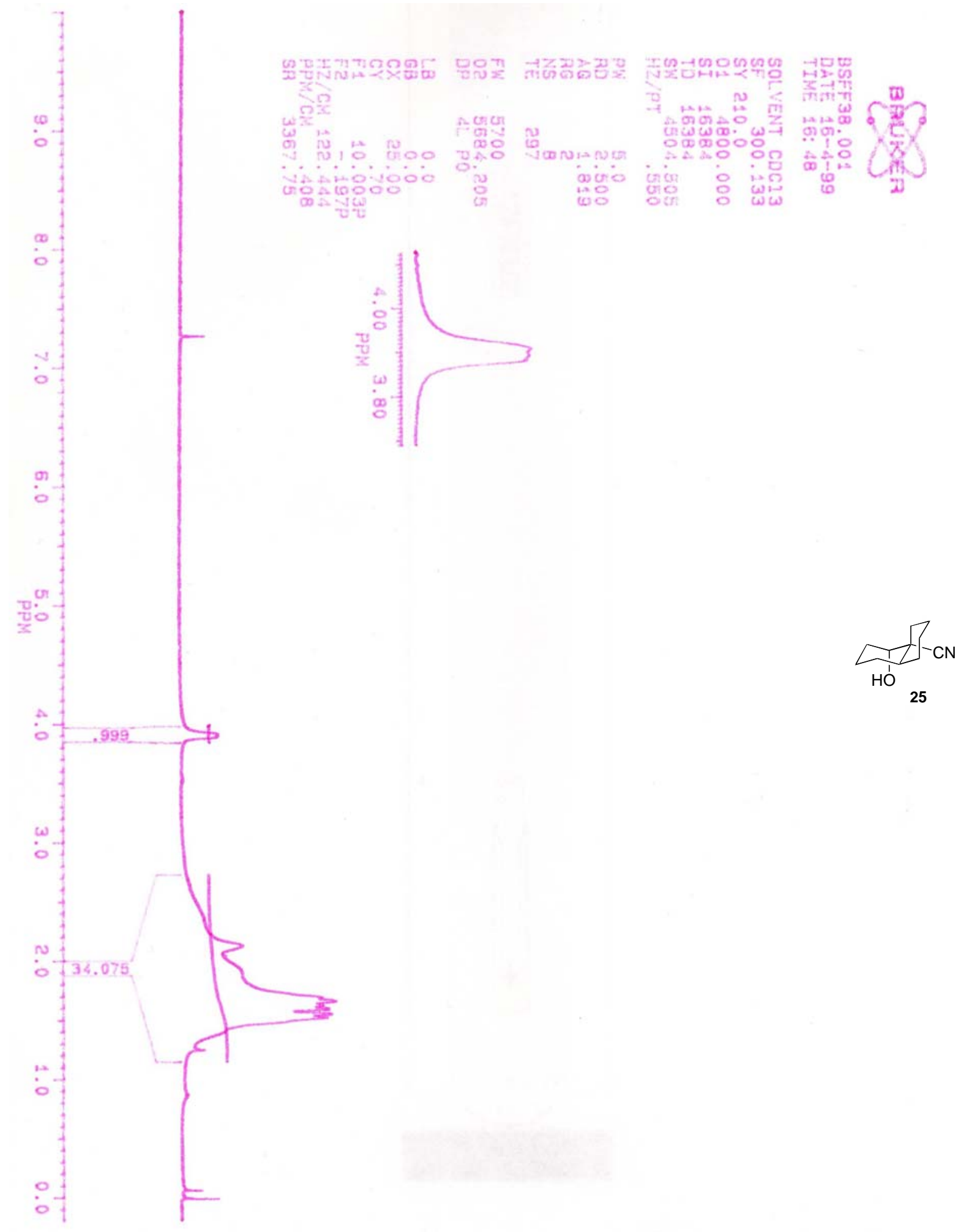




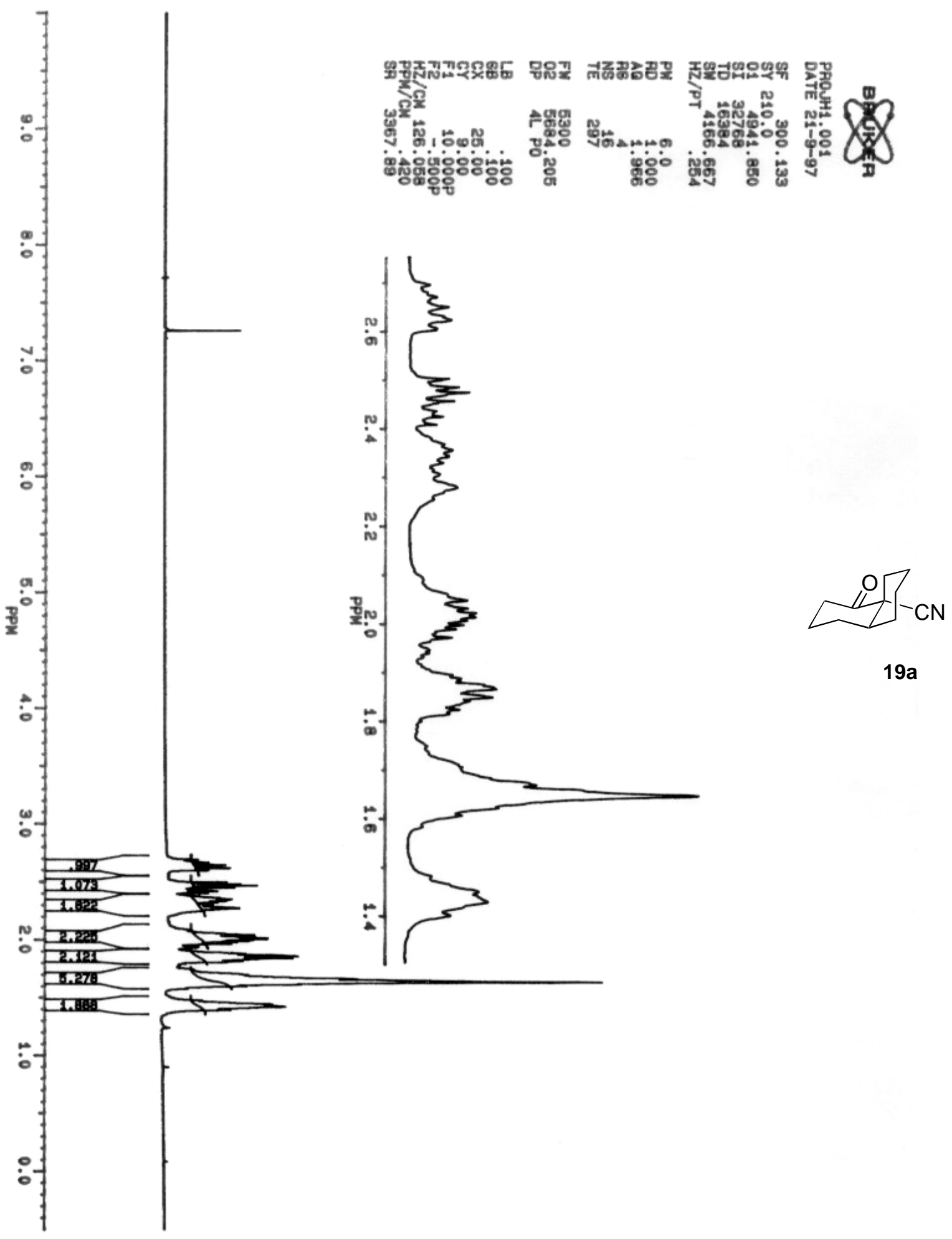




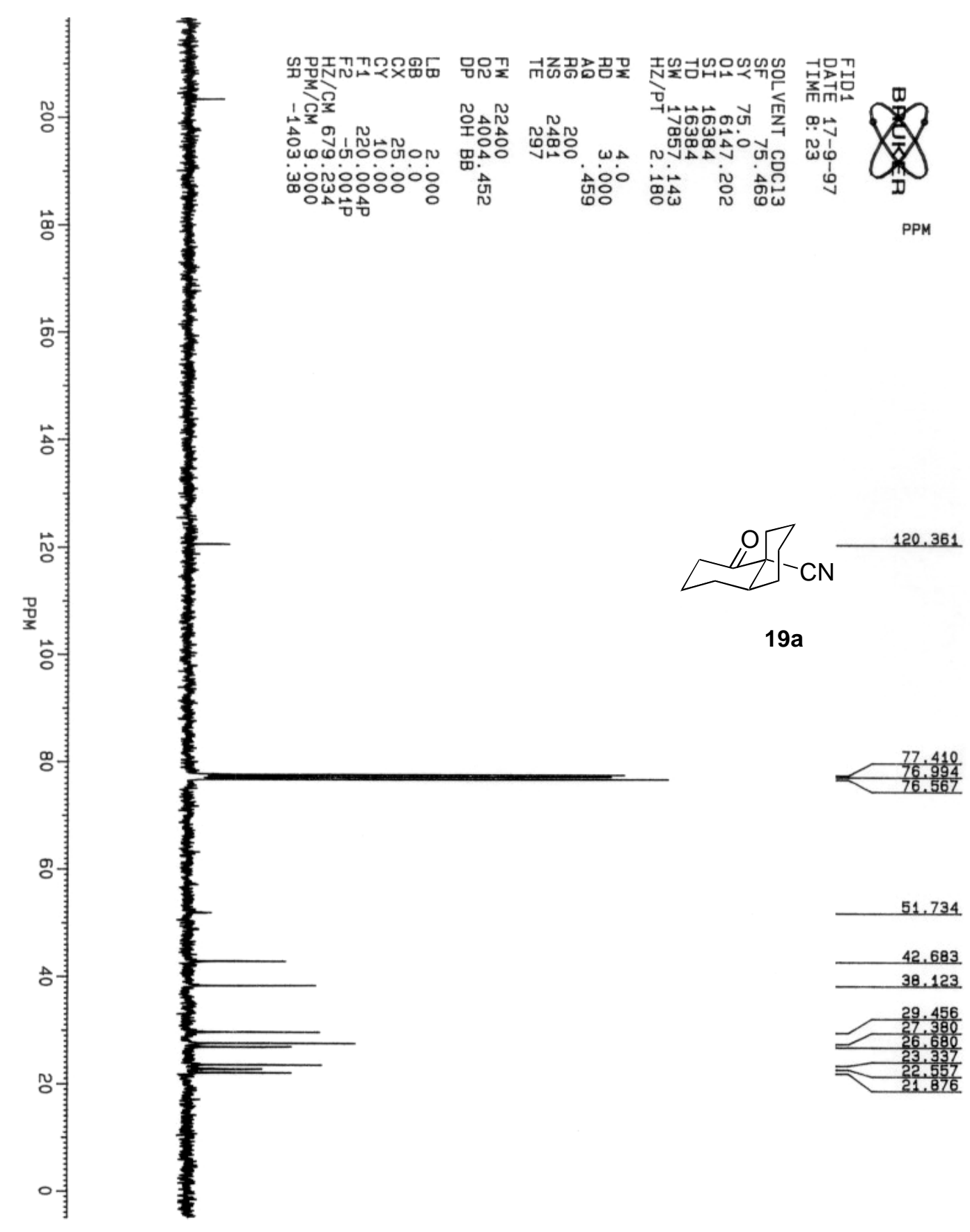




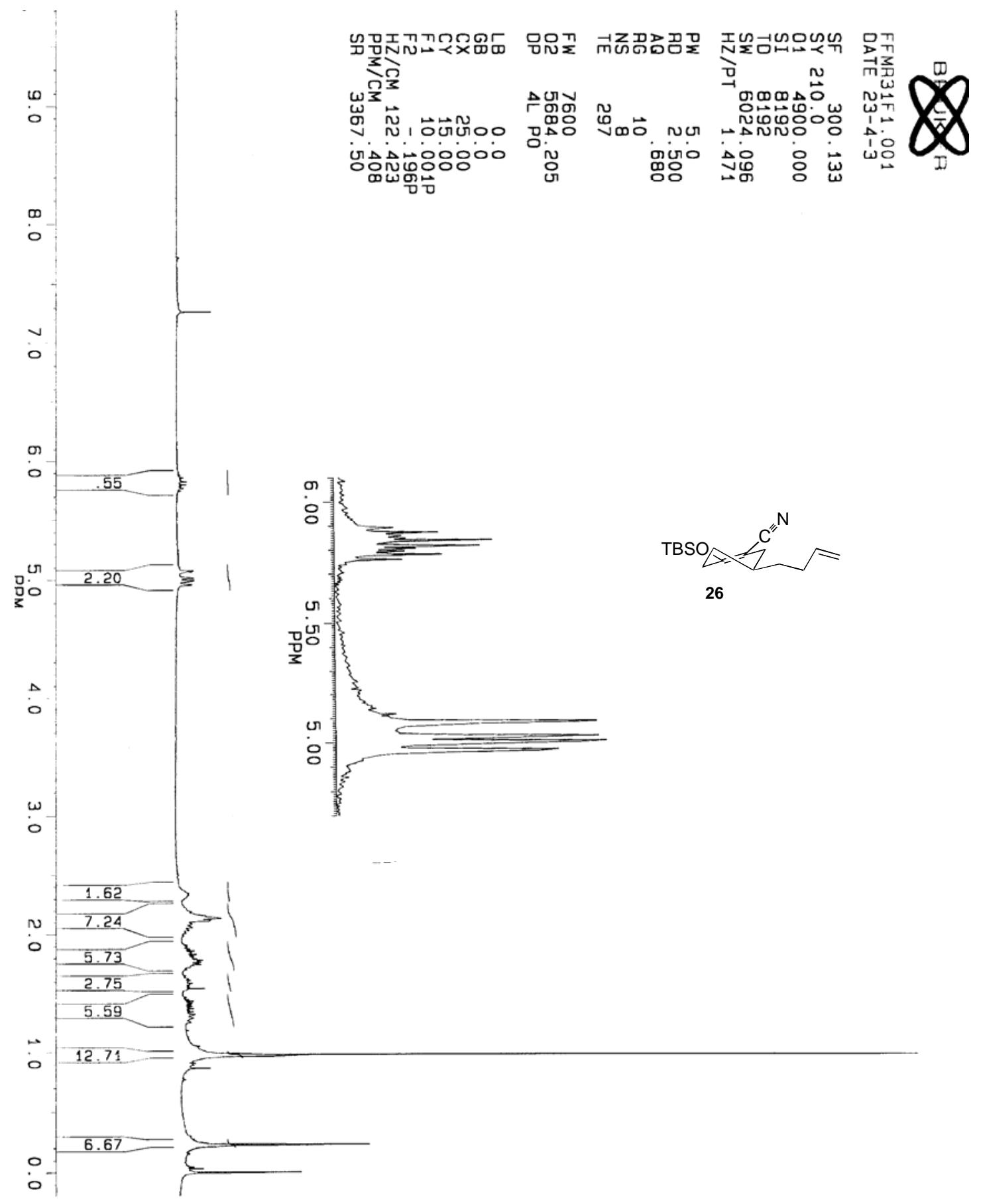




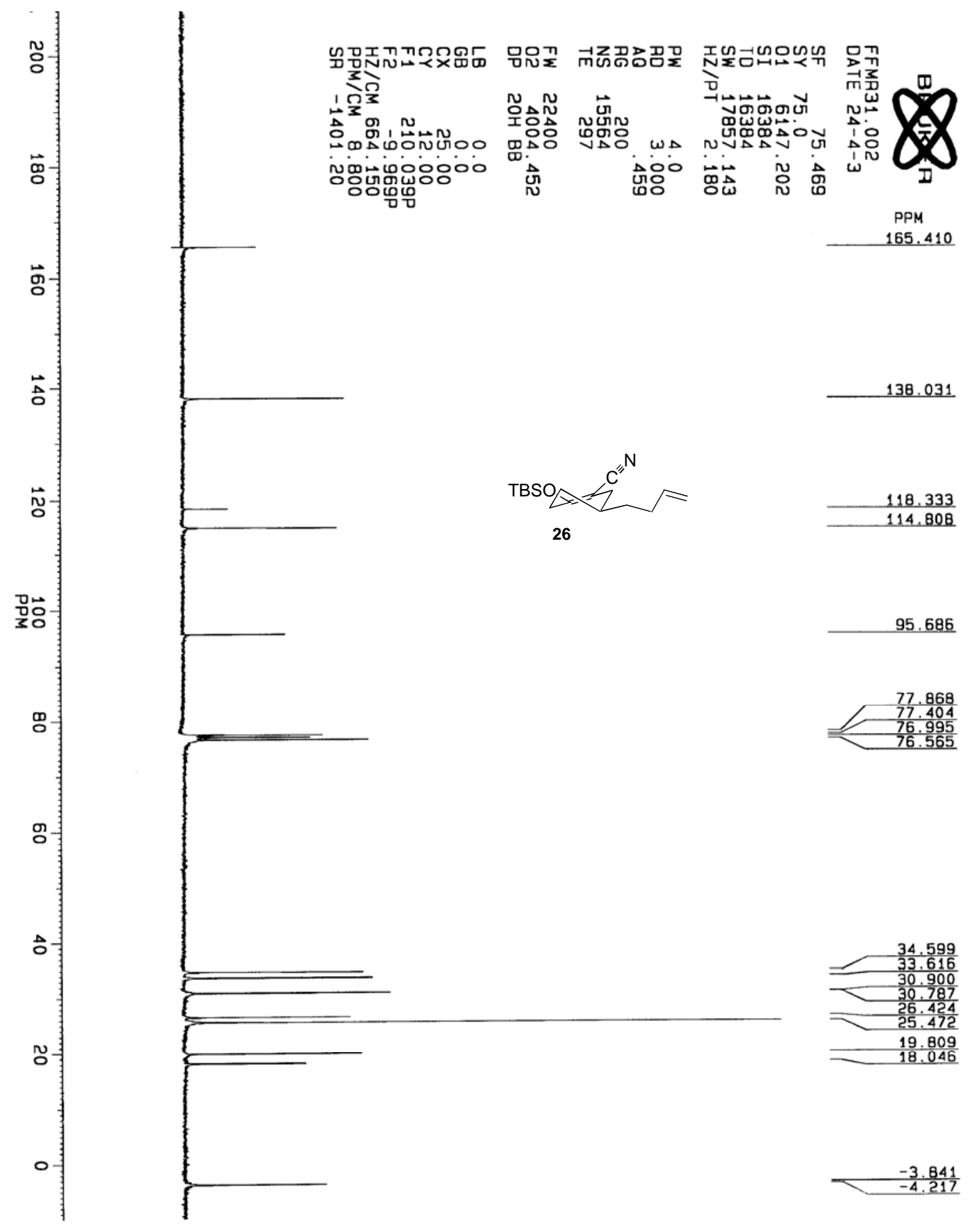




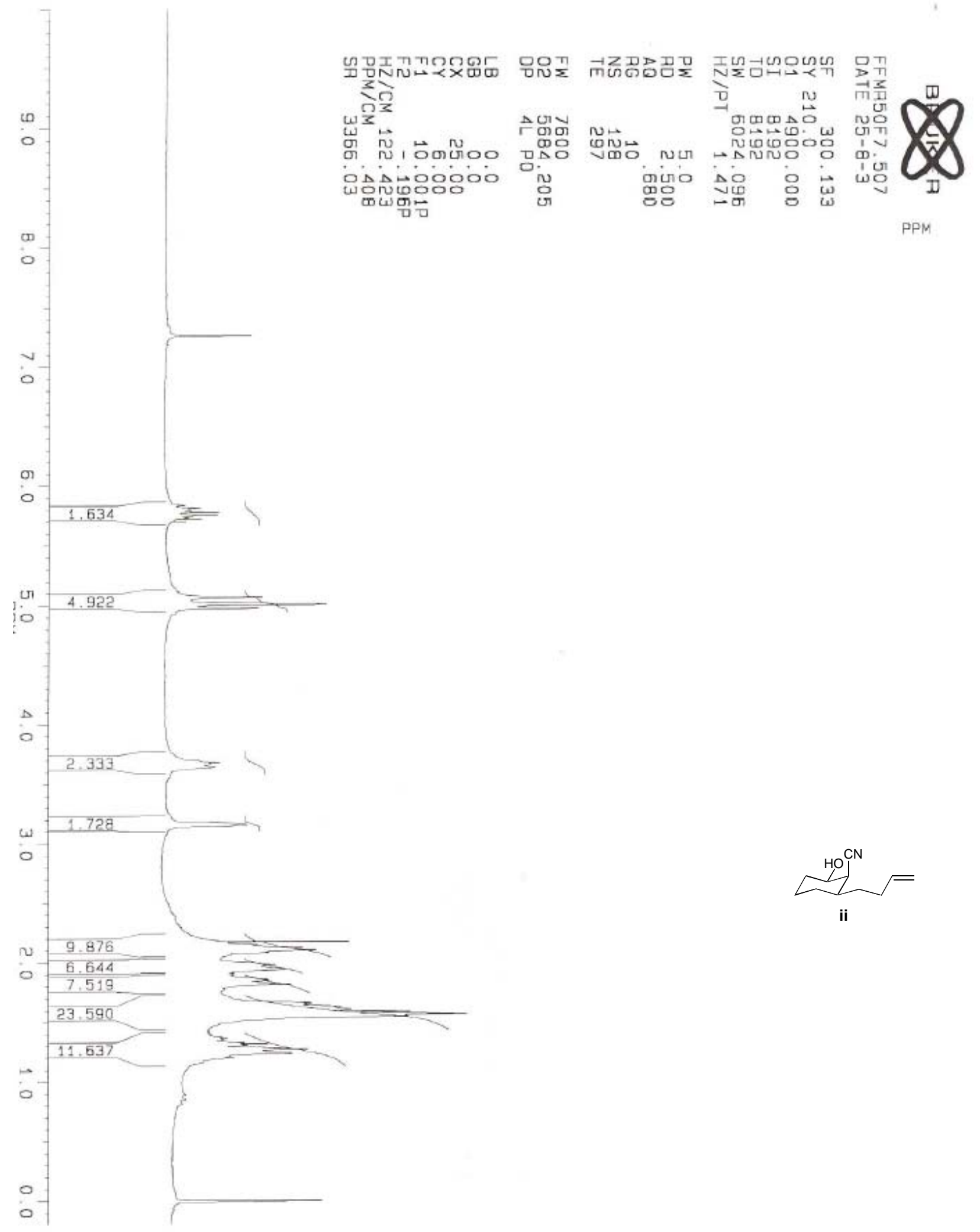




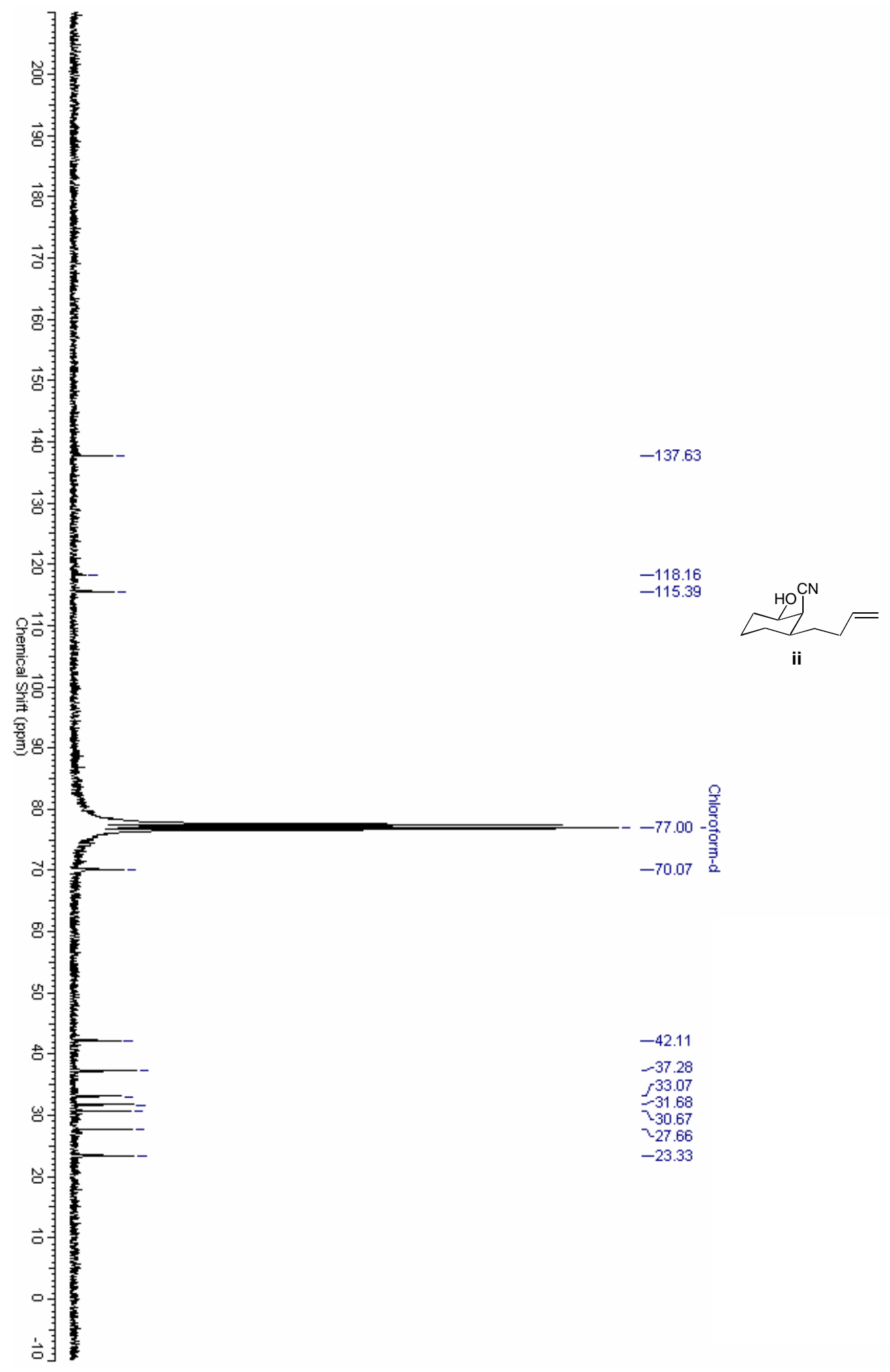




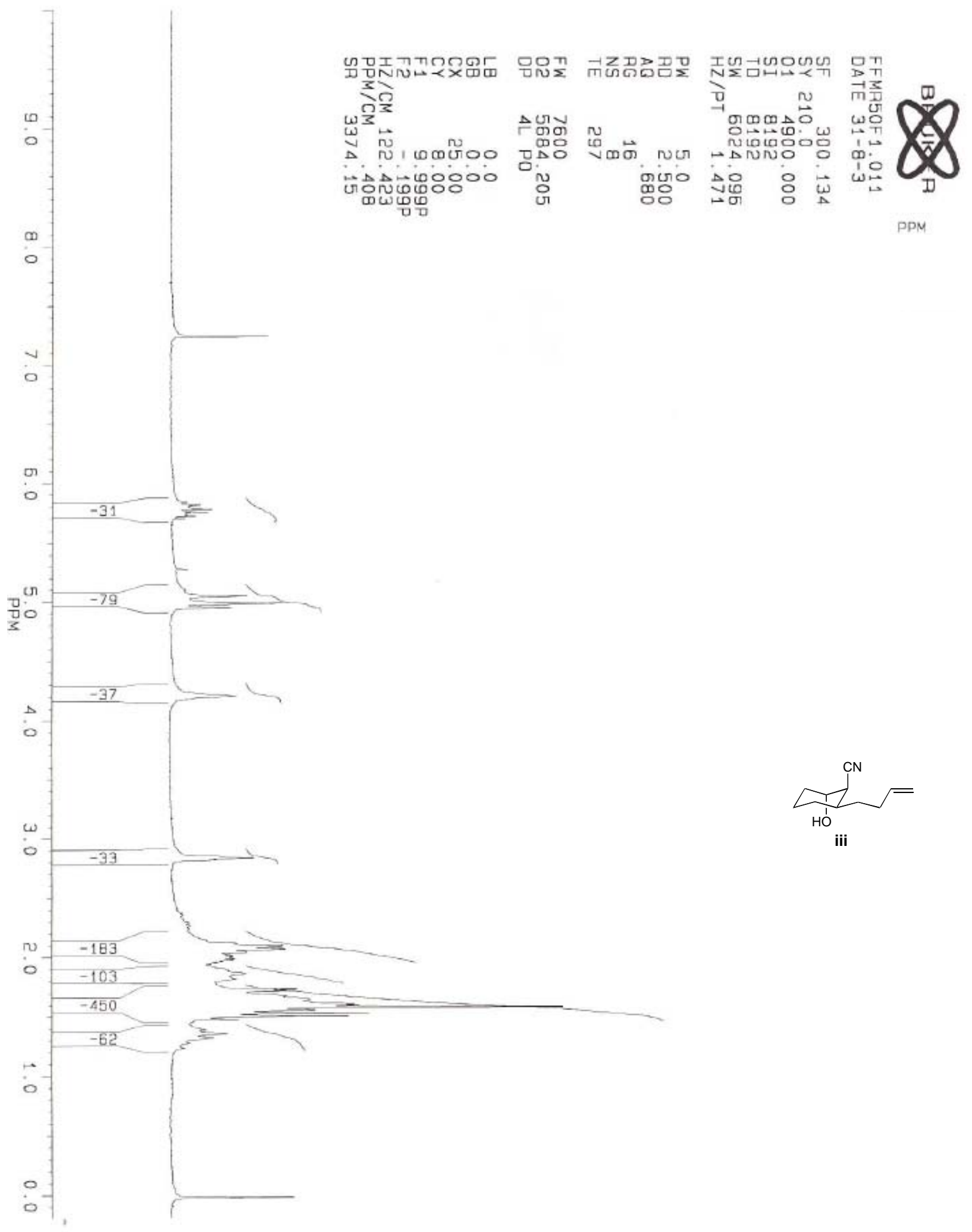




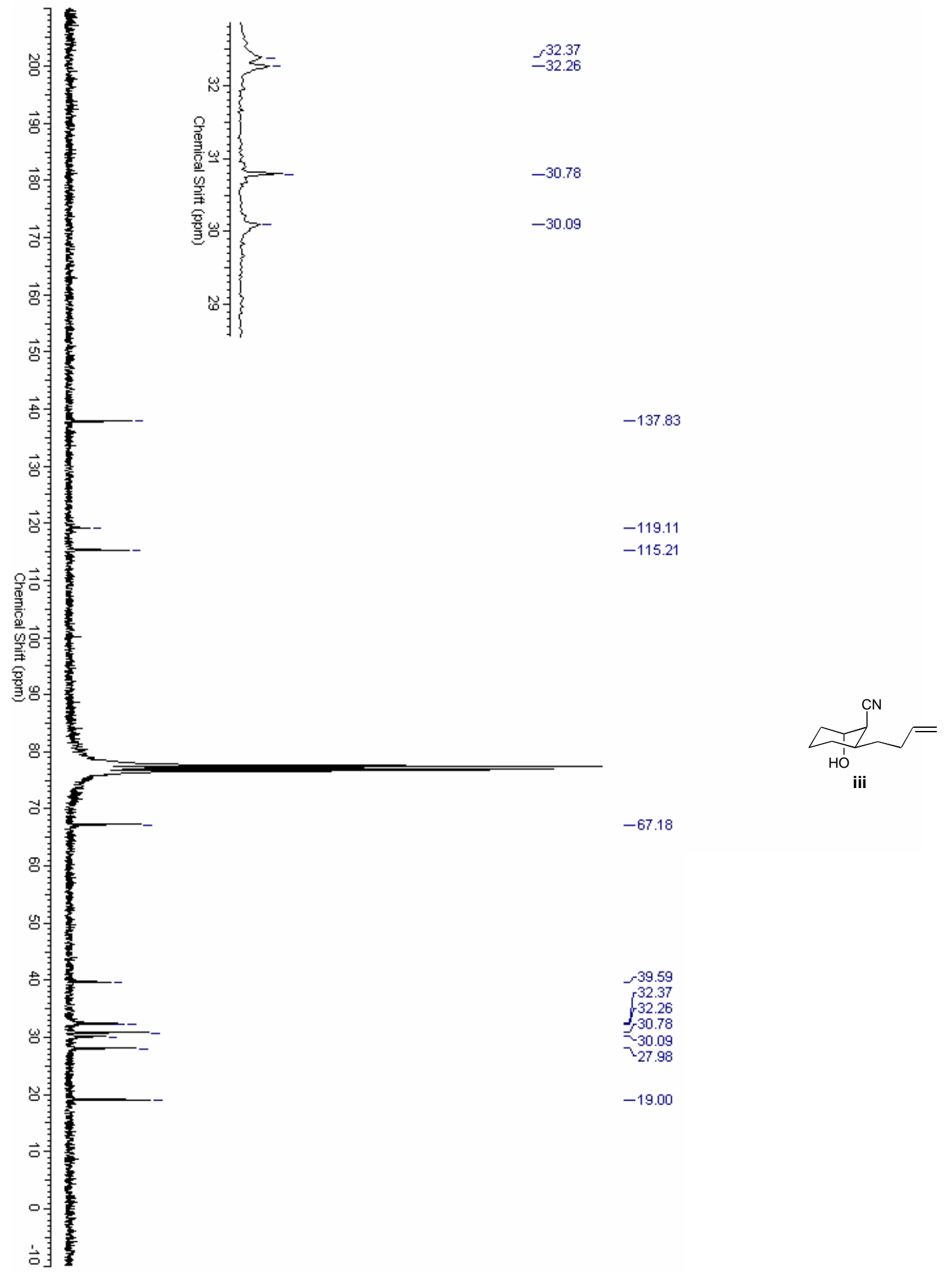




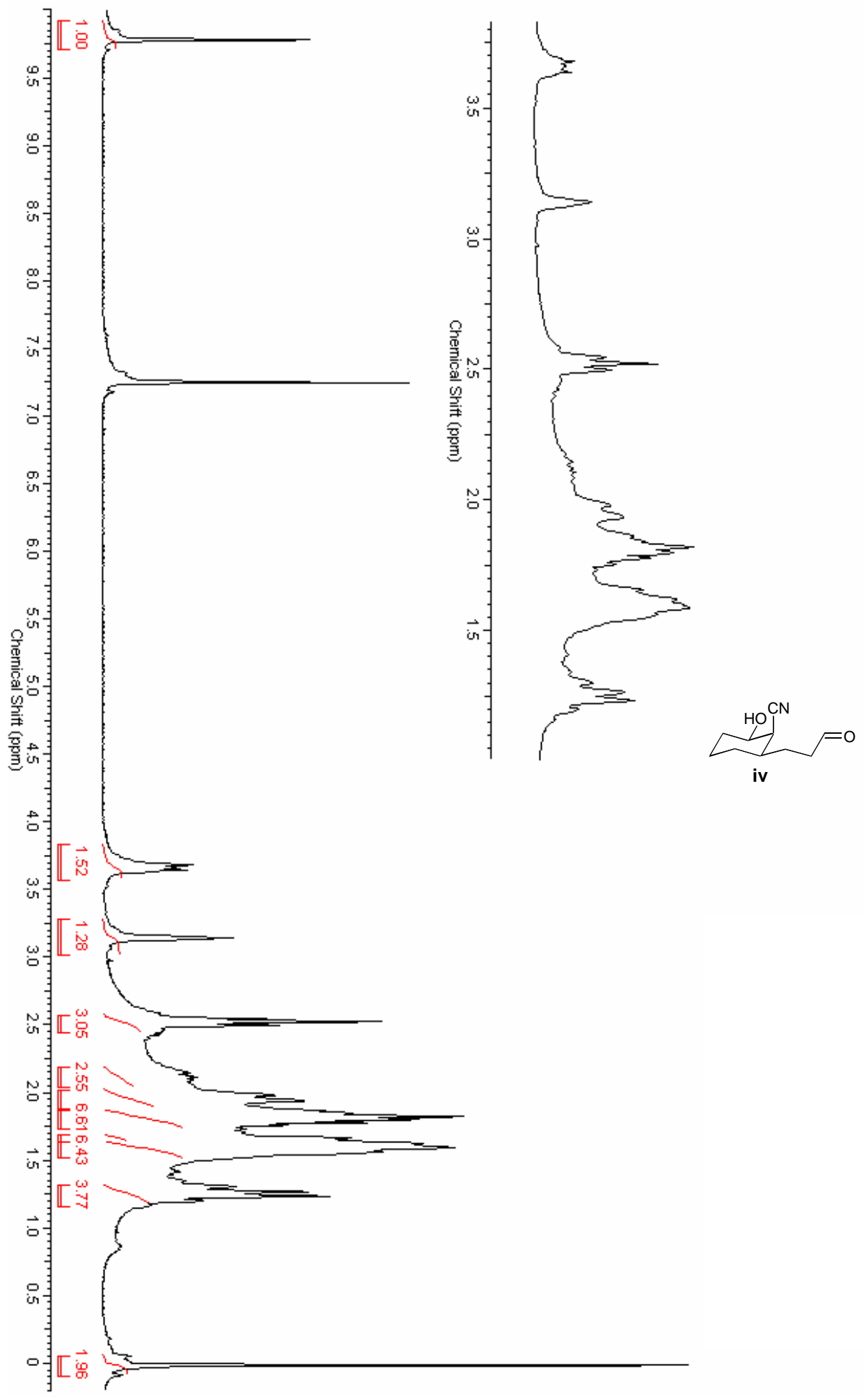




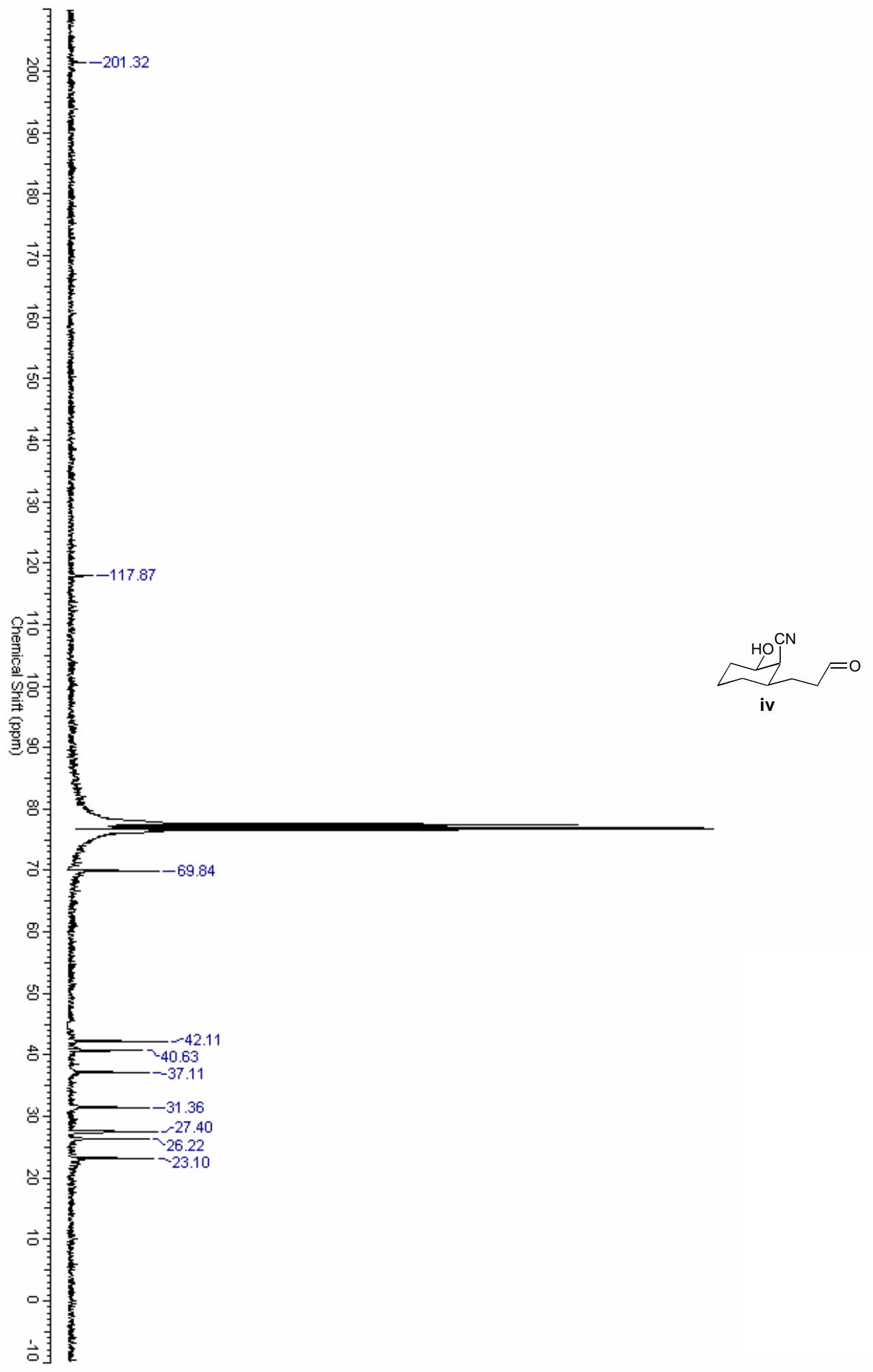




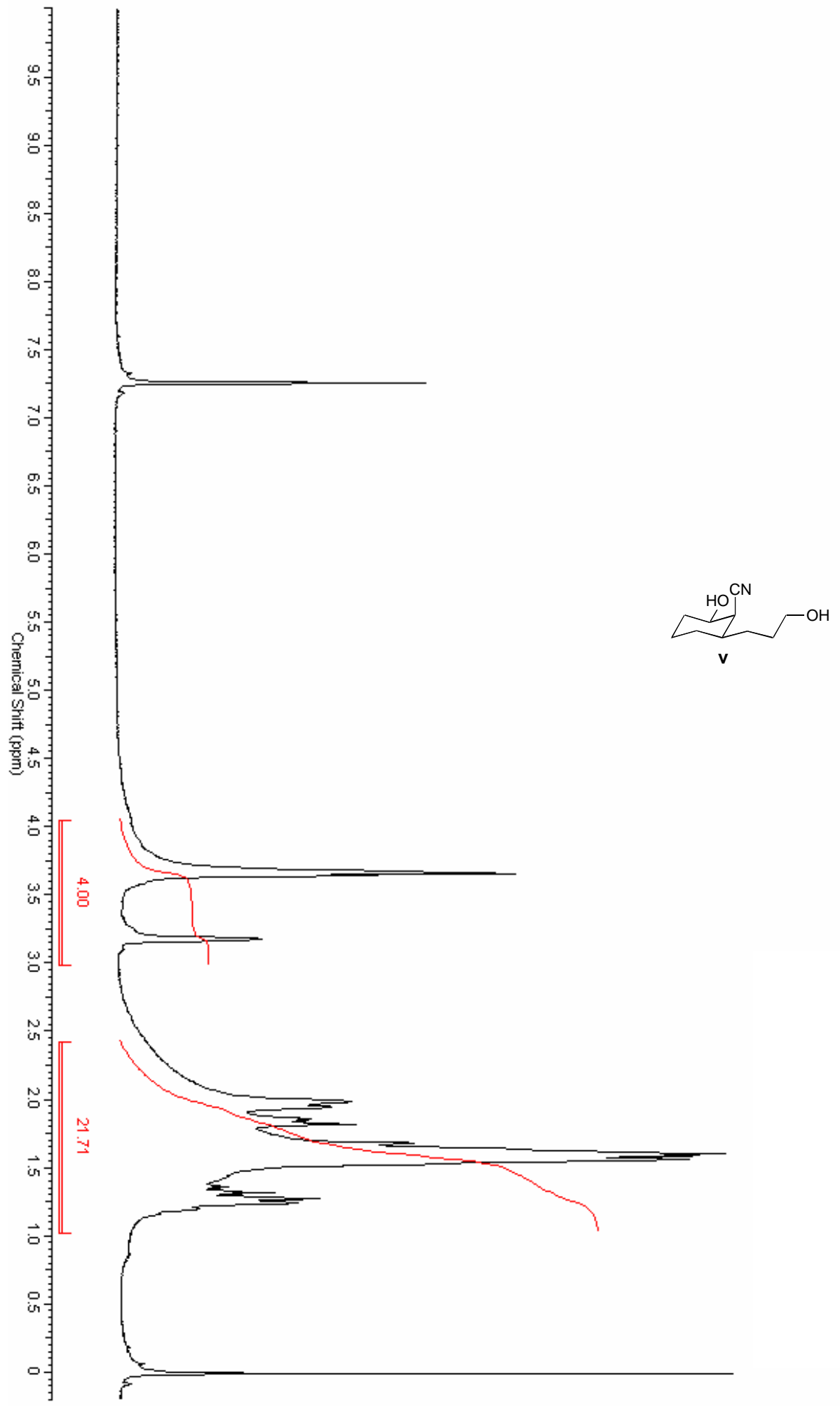




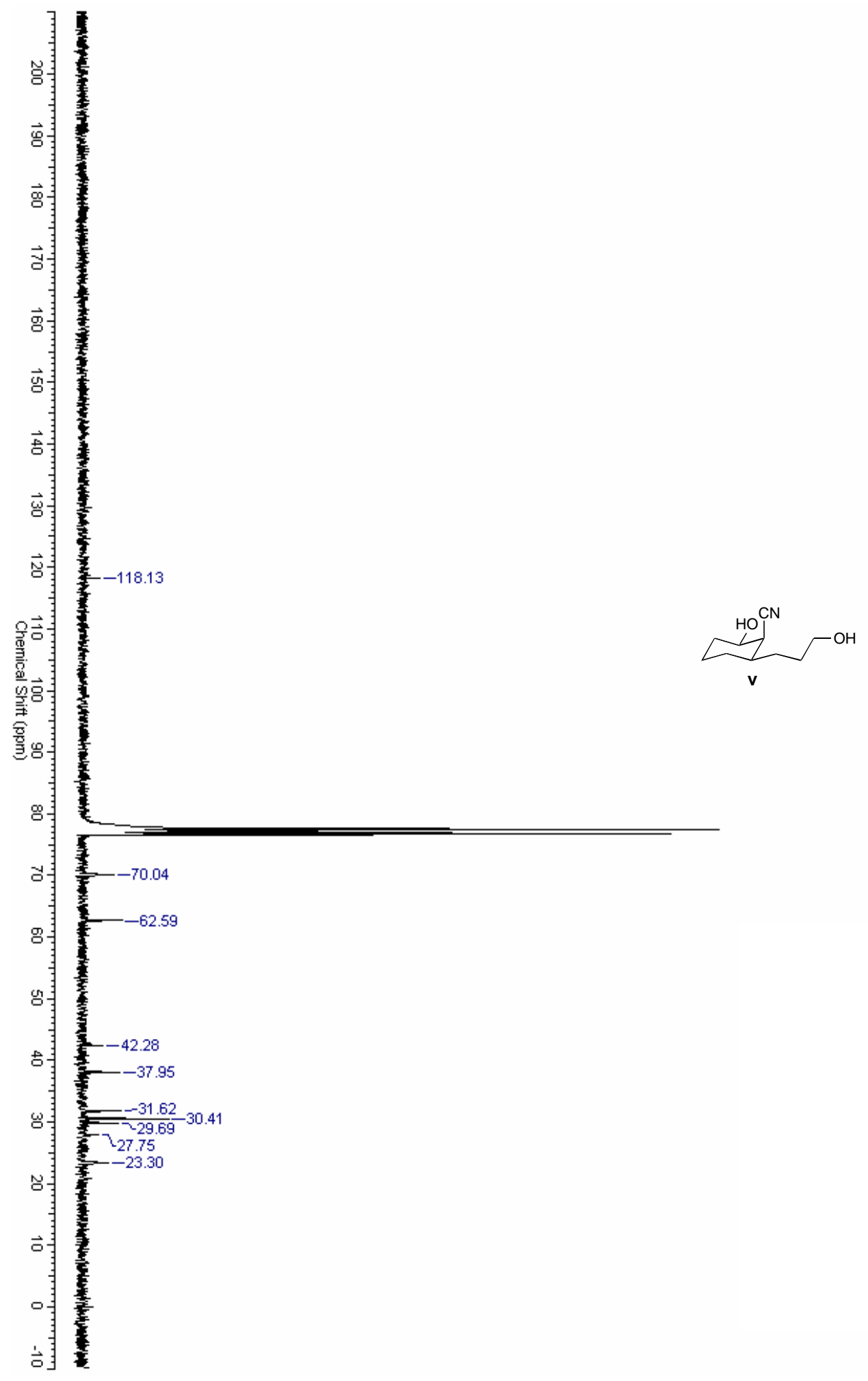




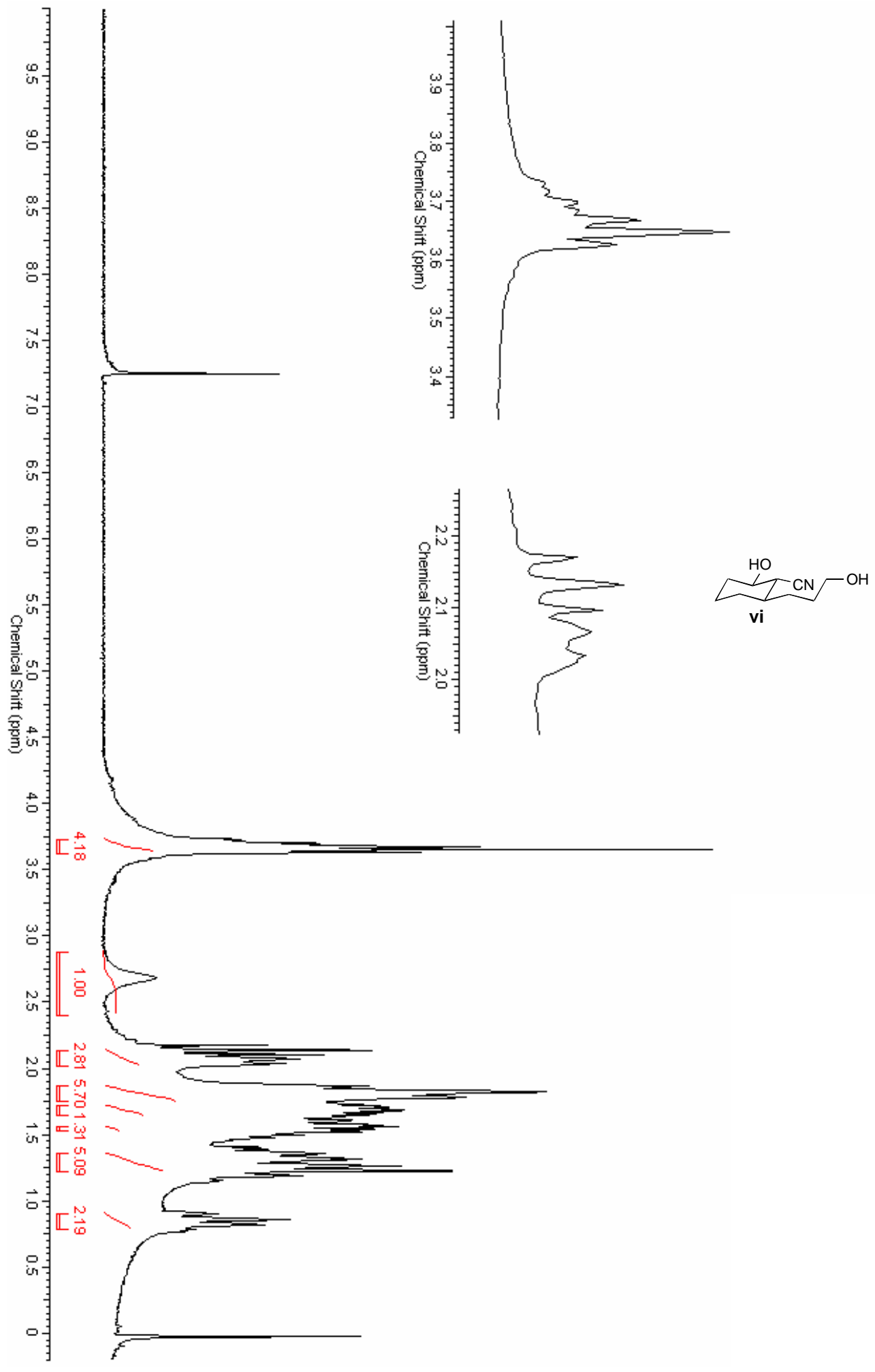




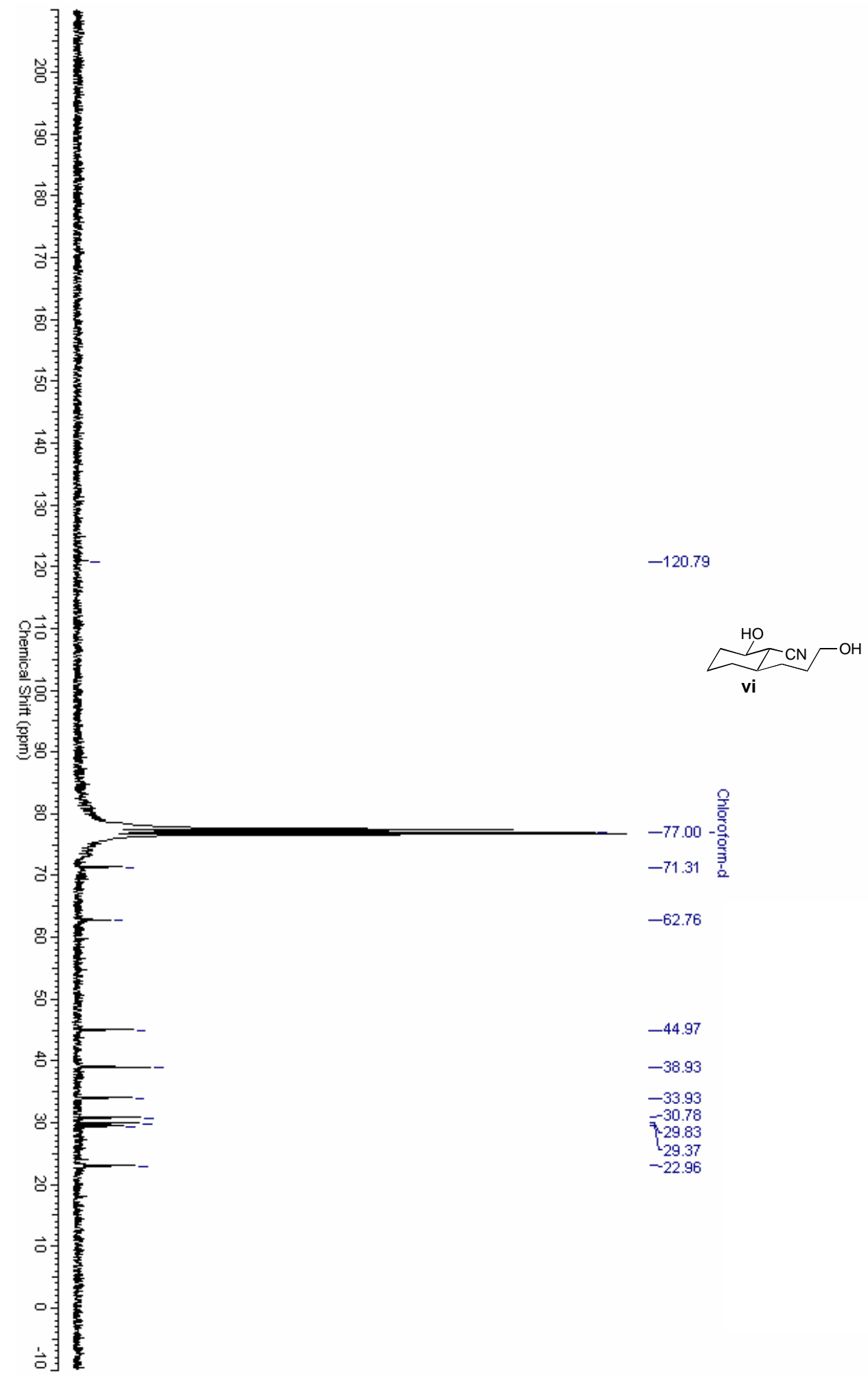




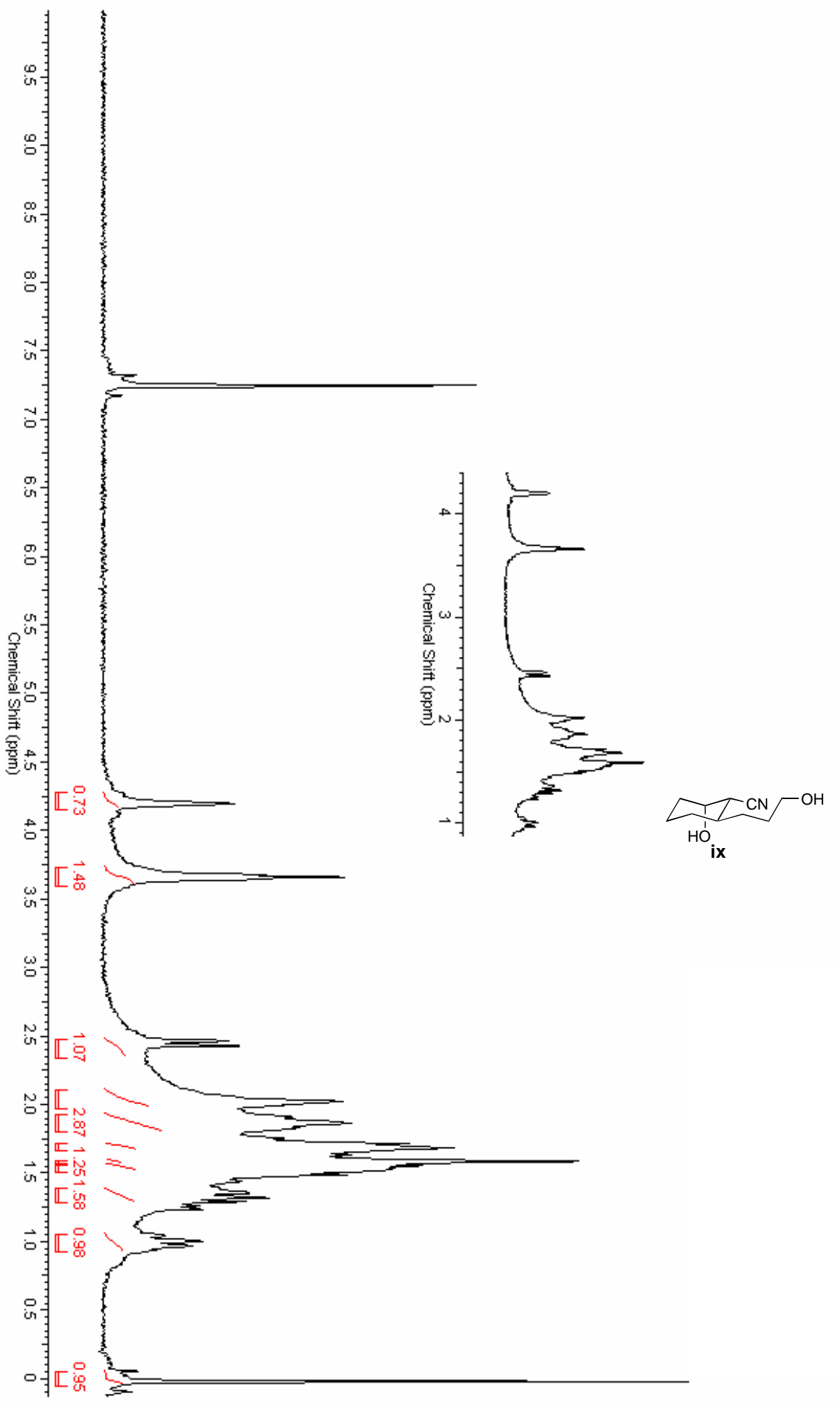




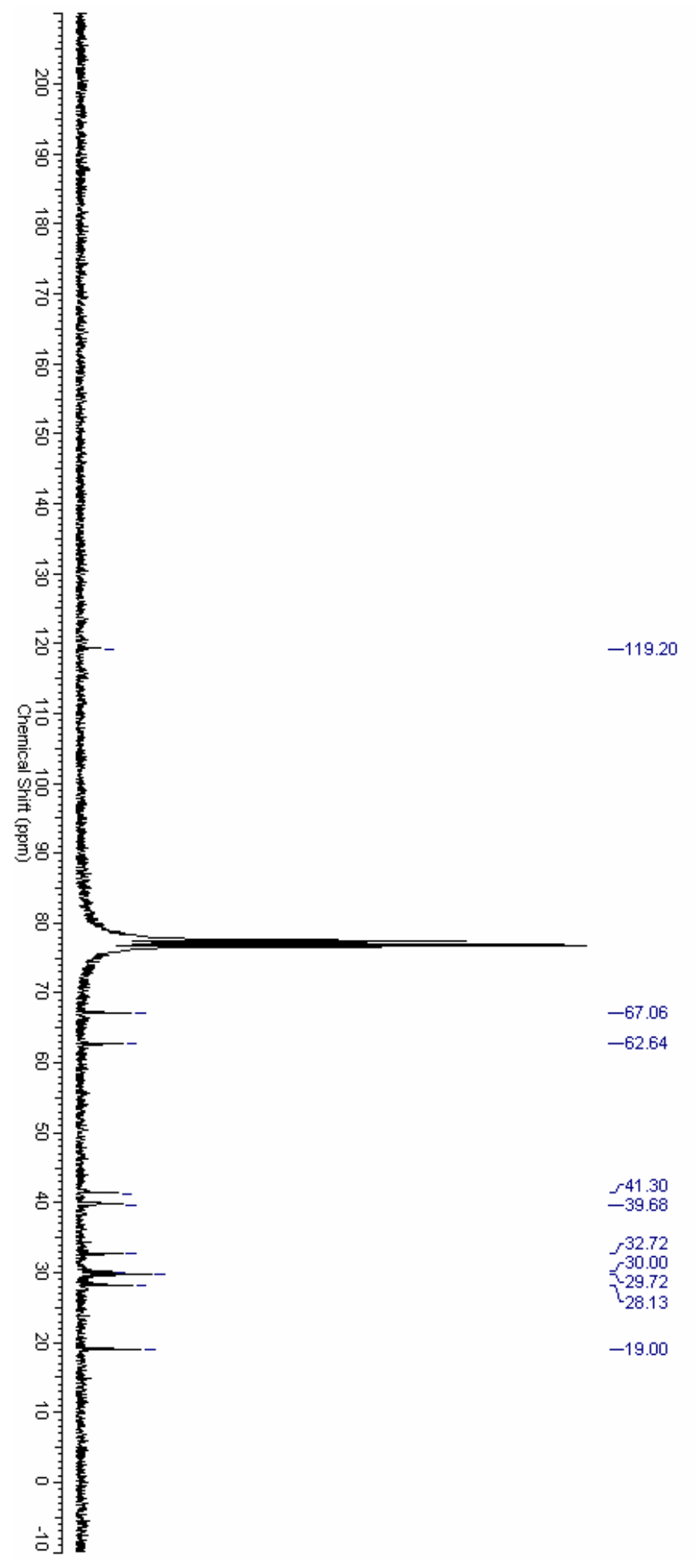




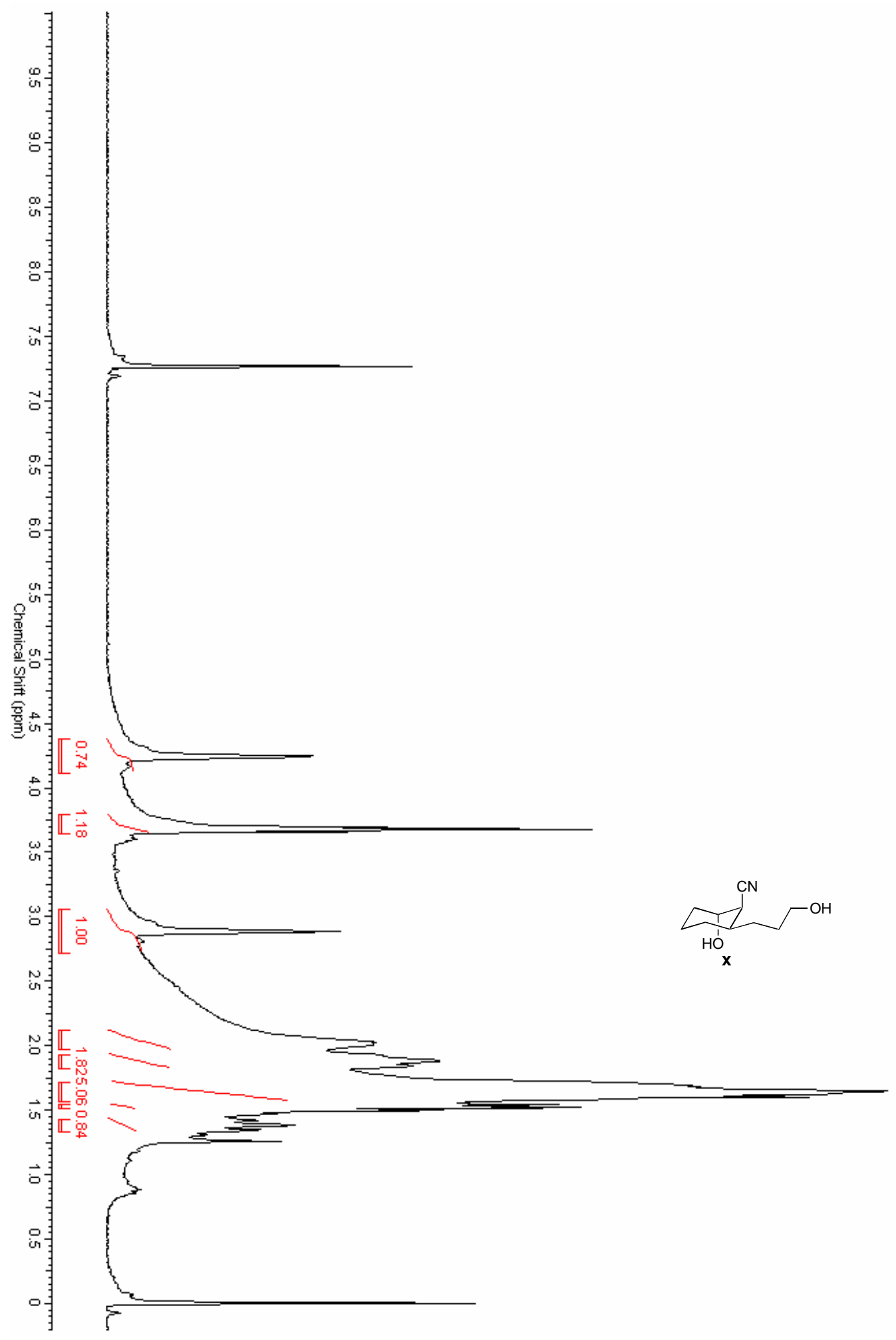




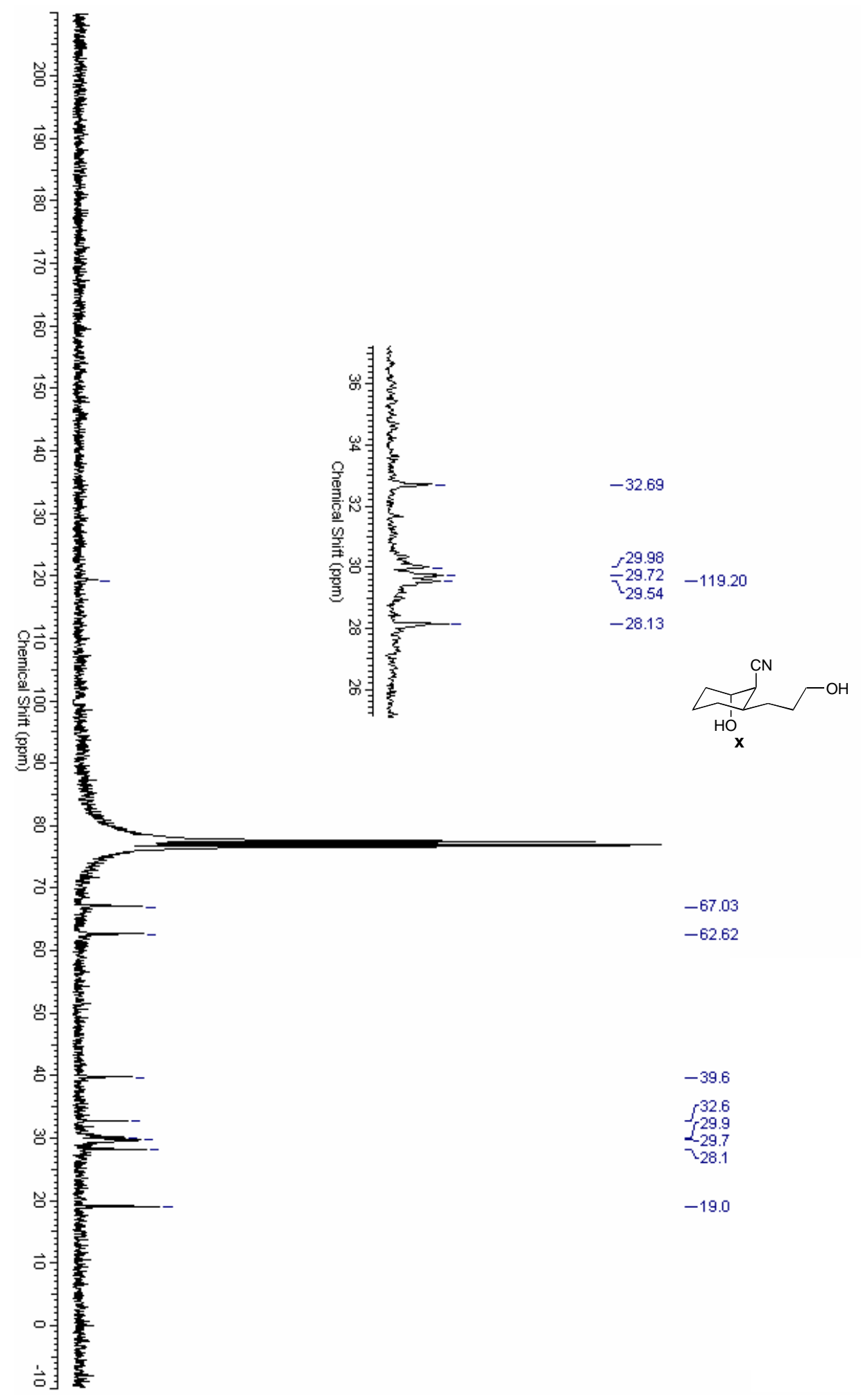




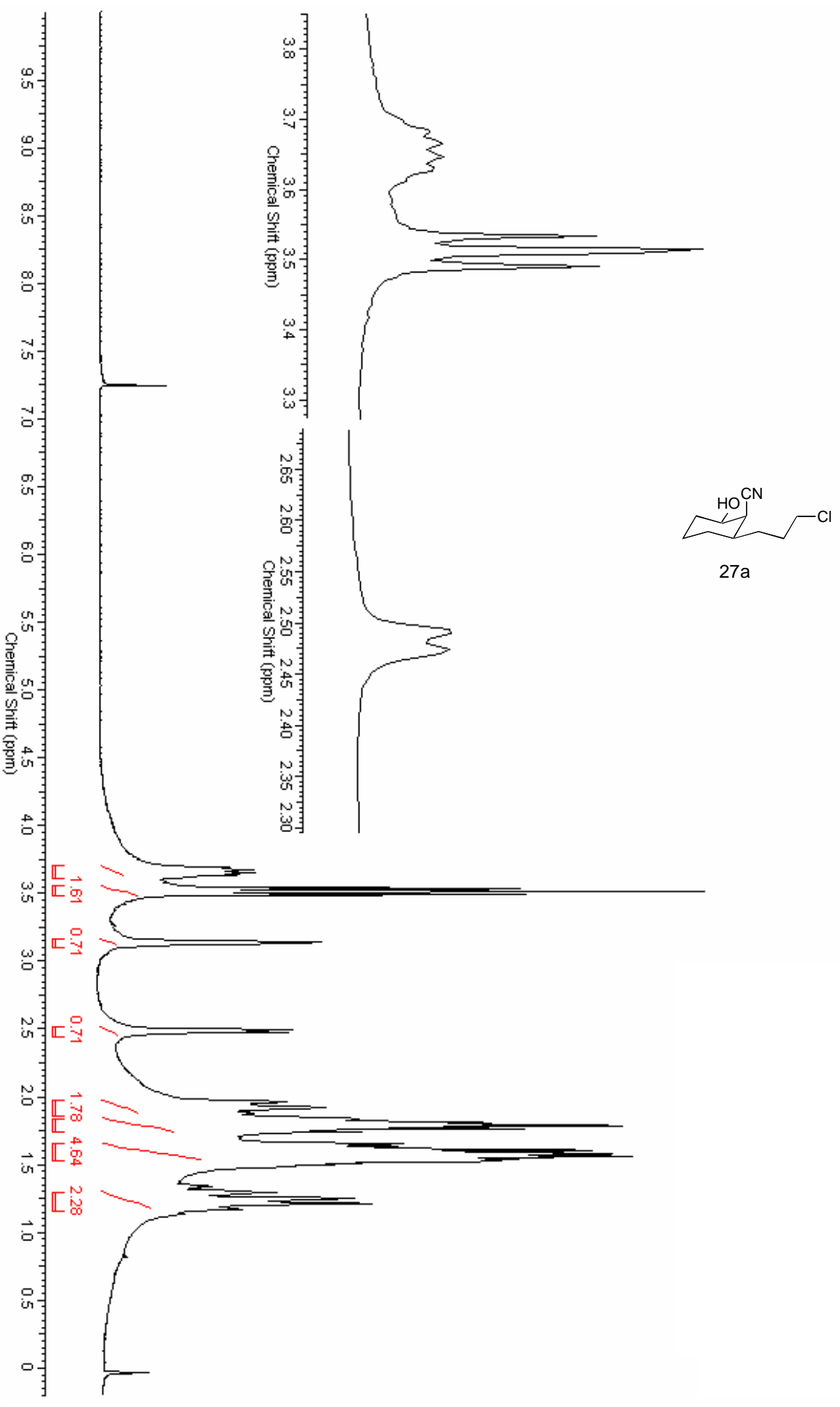




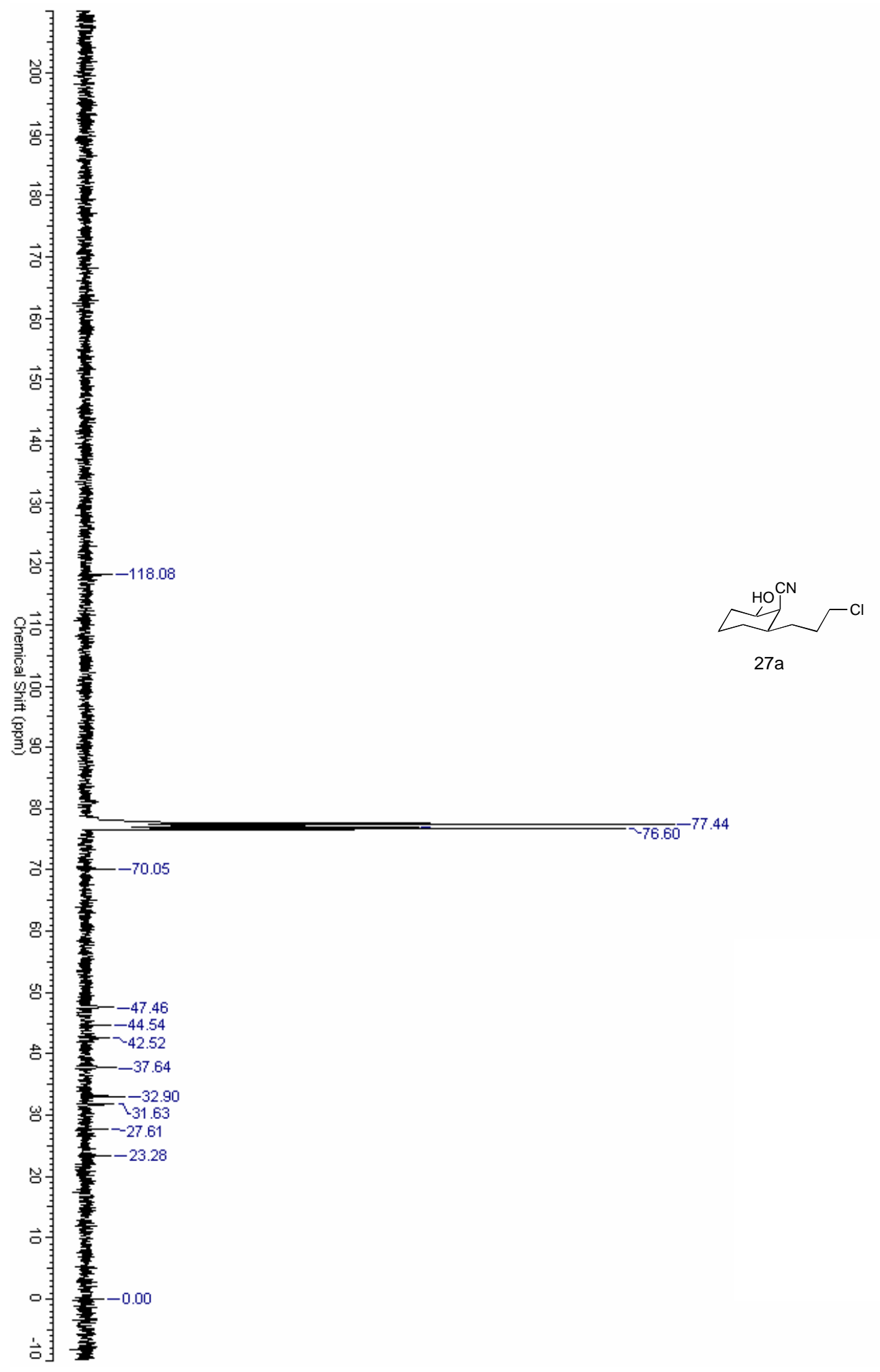




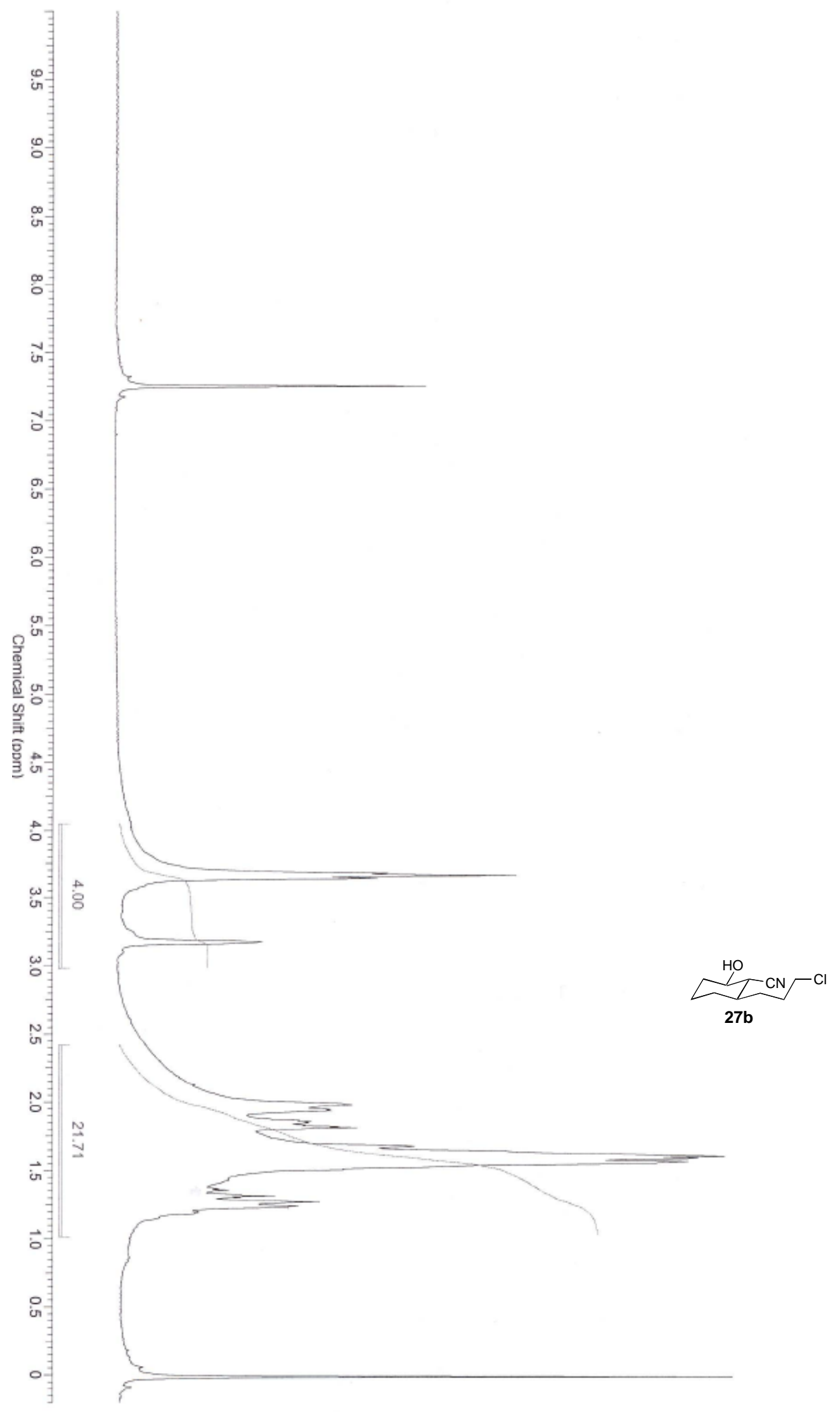

S49 


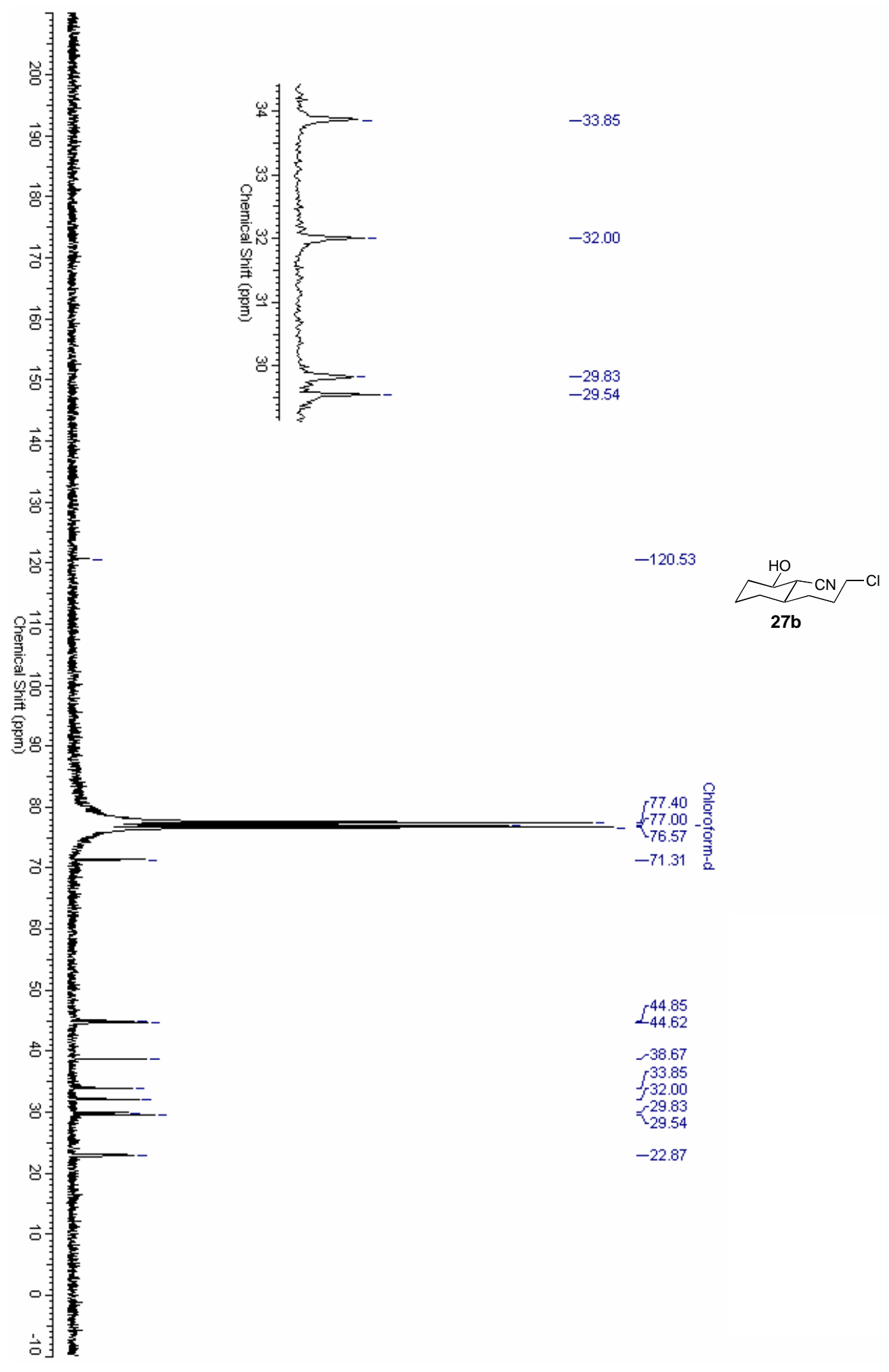




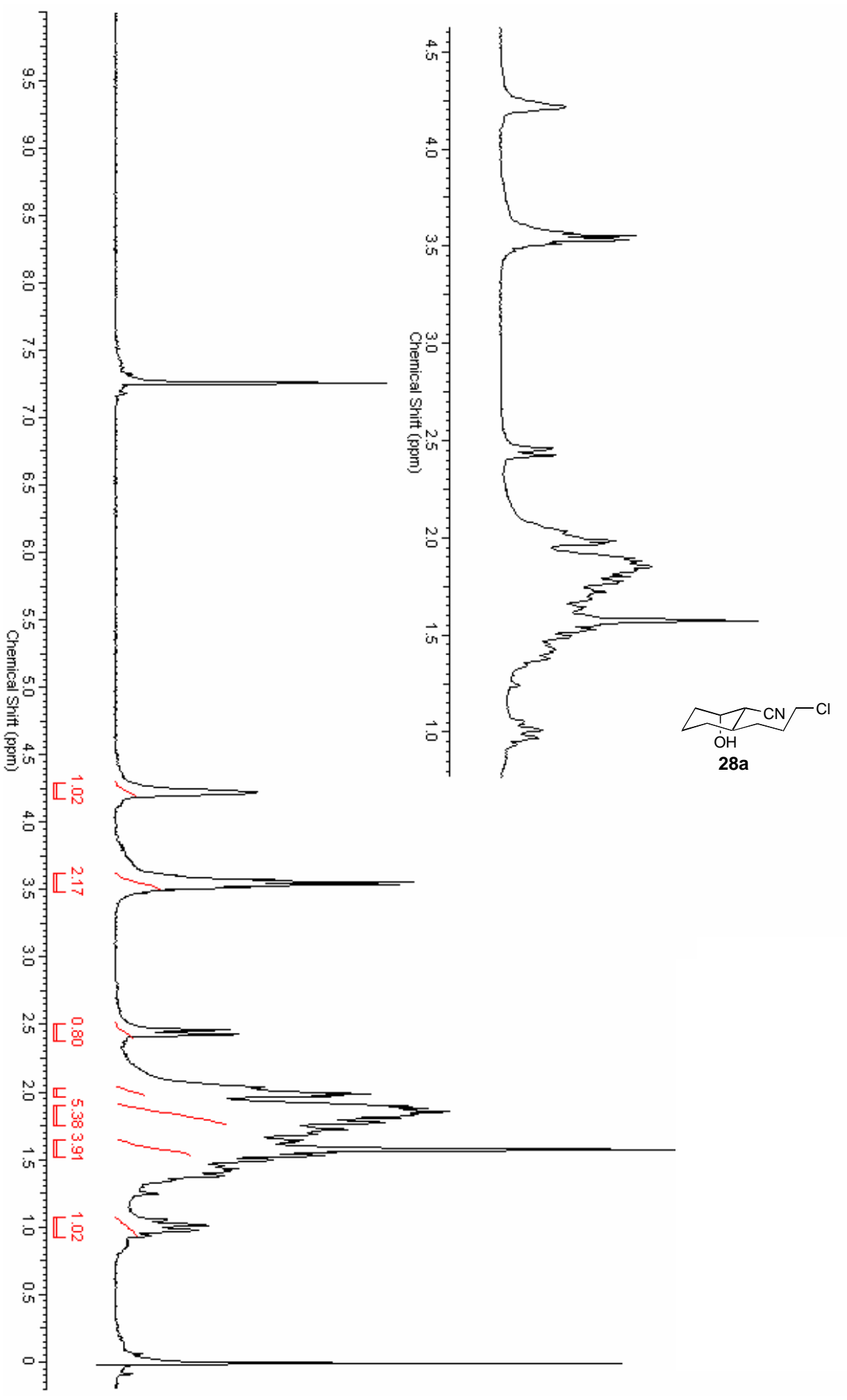




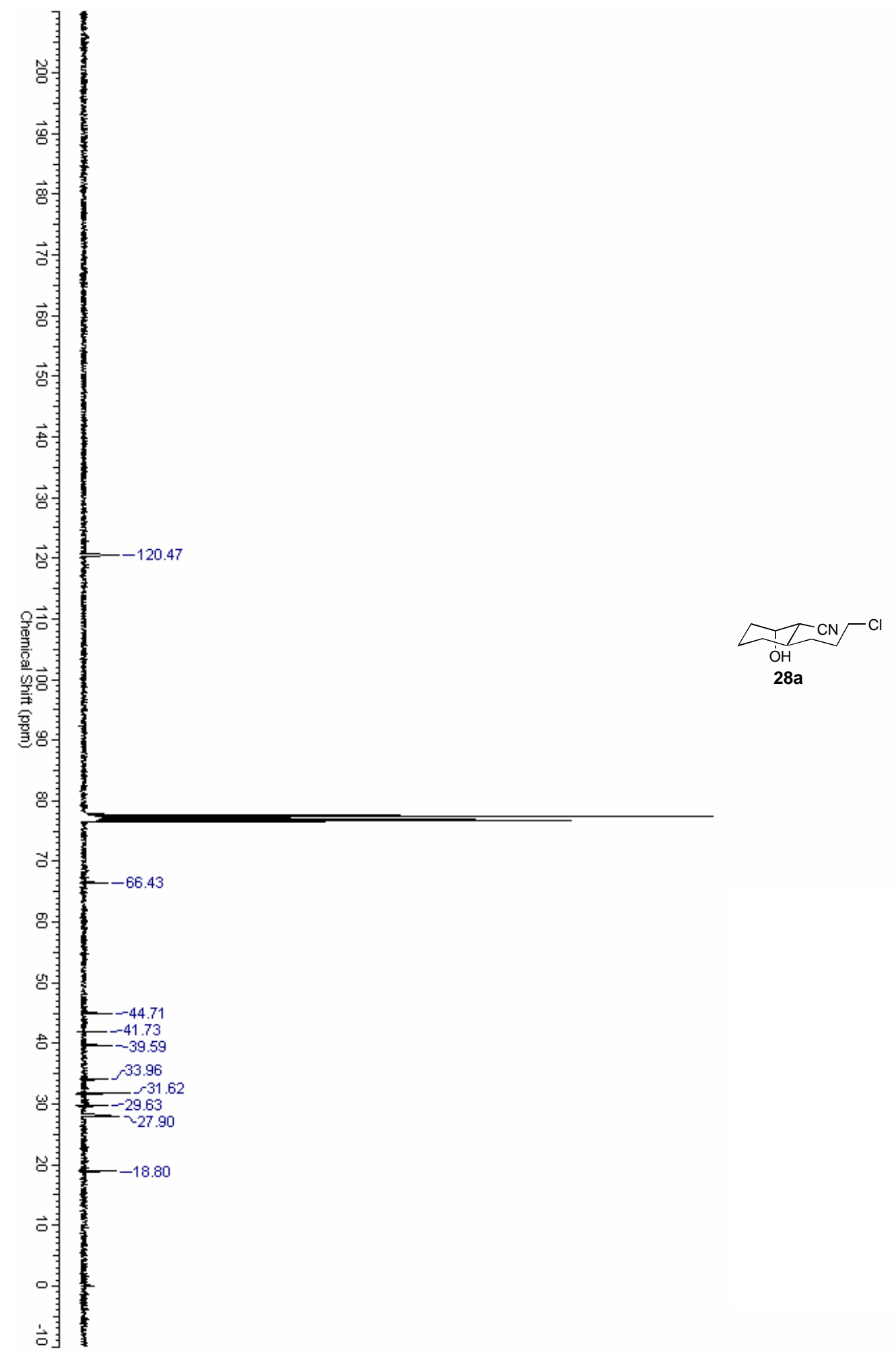




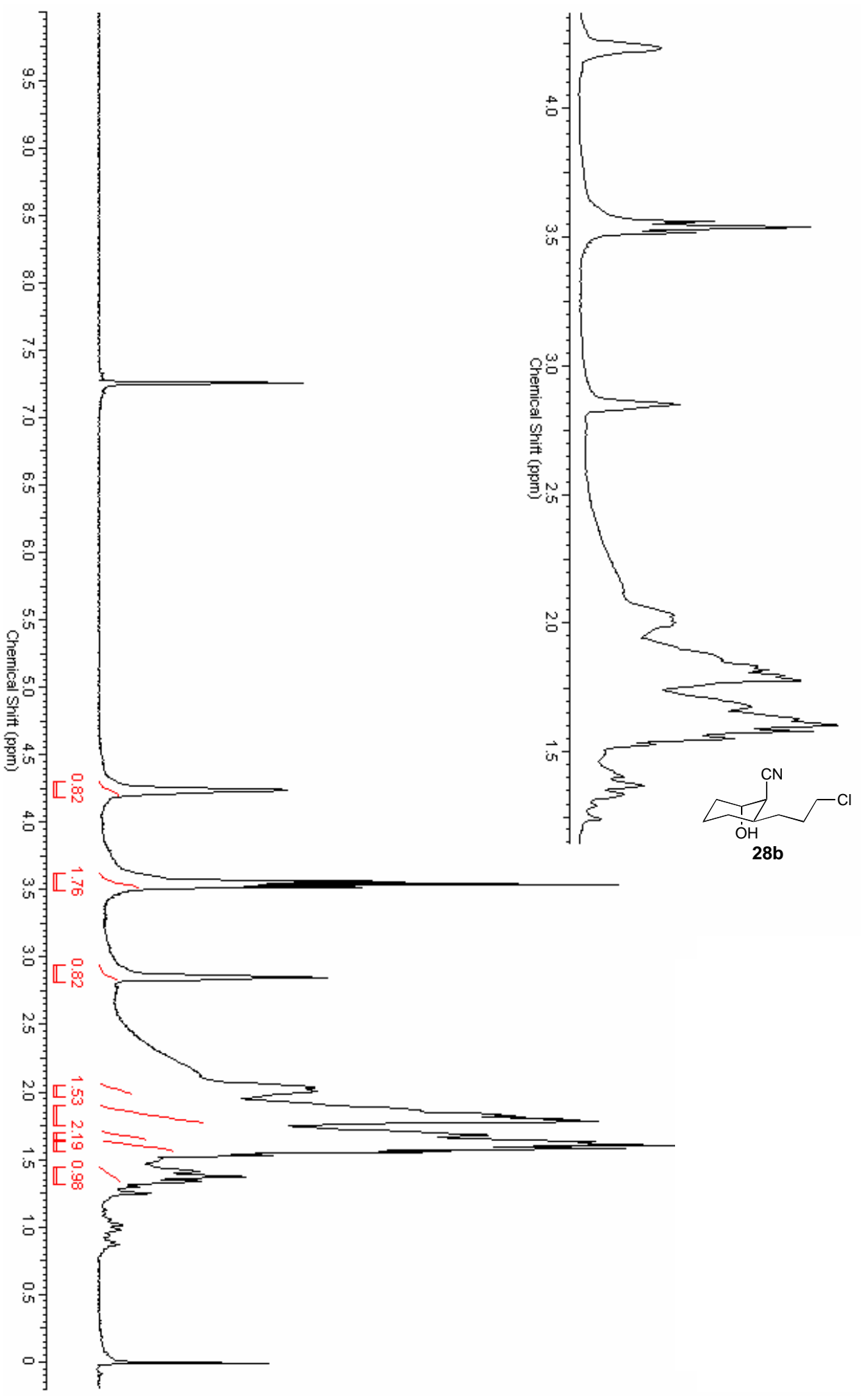




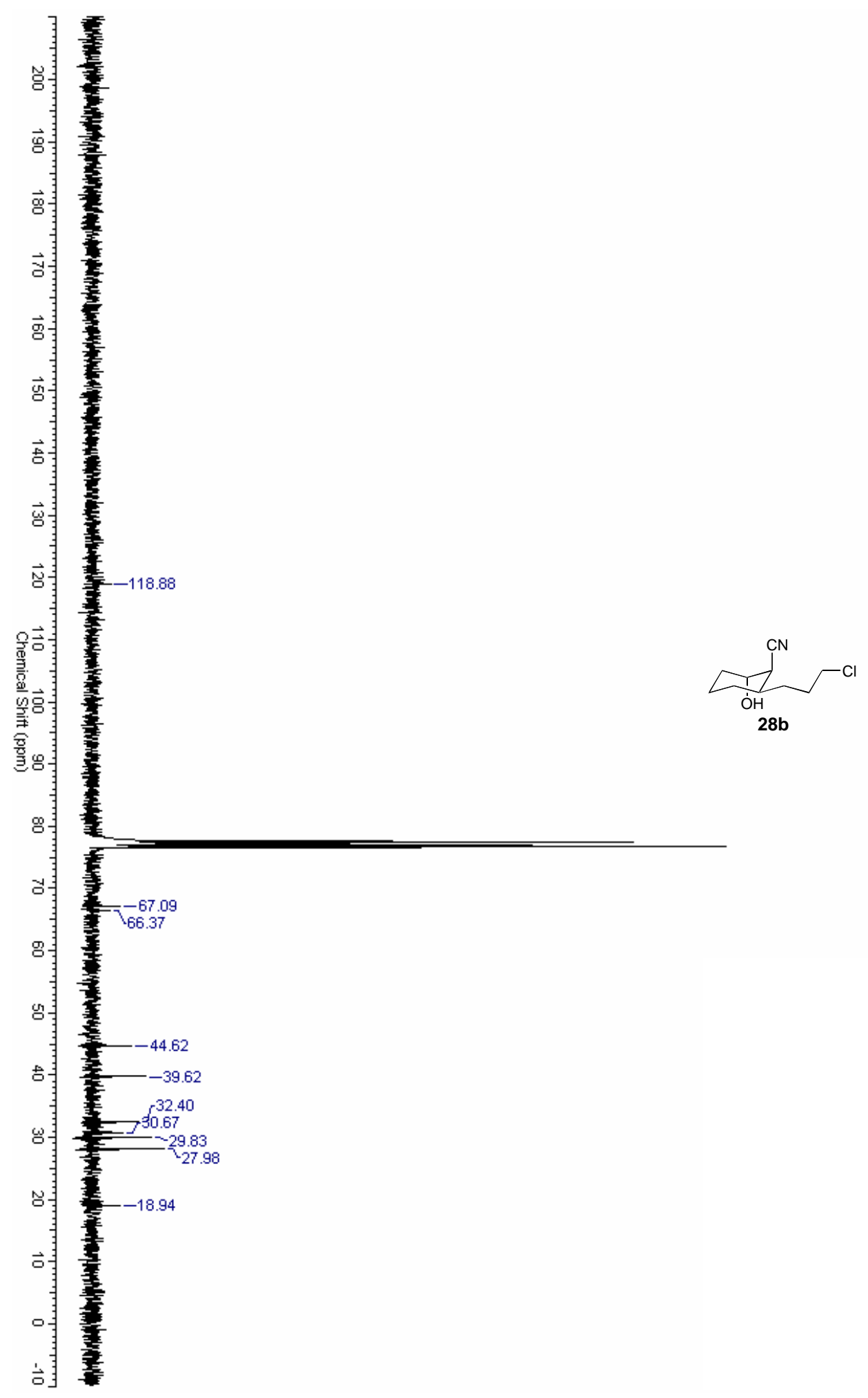




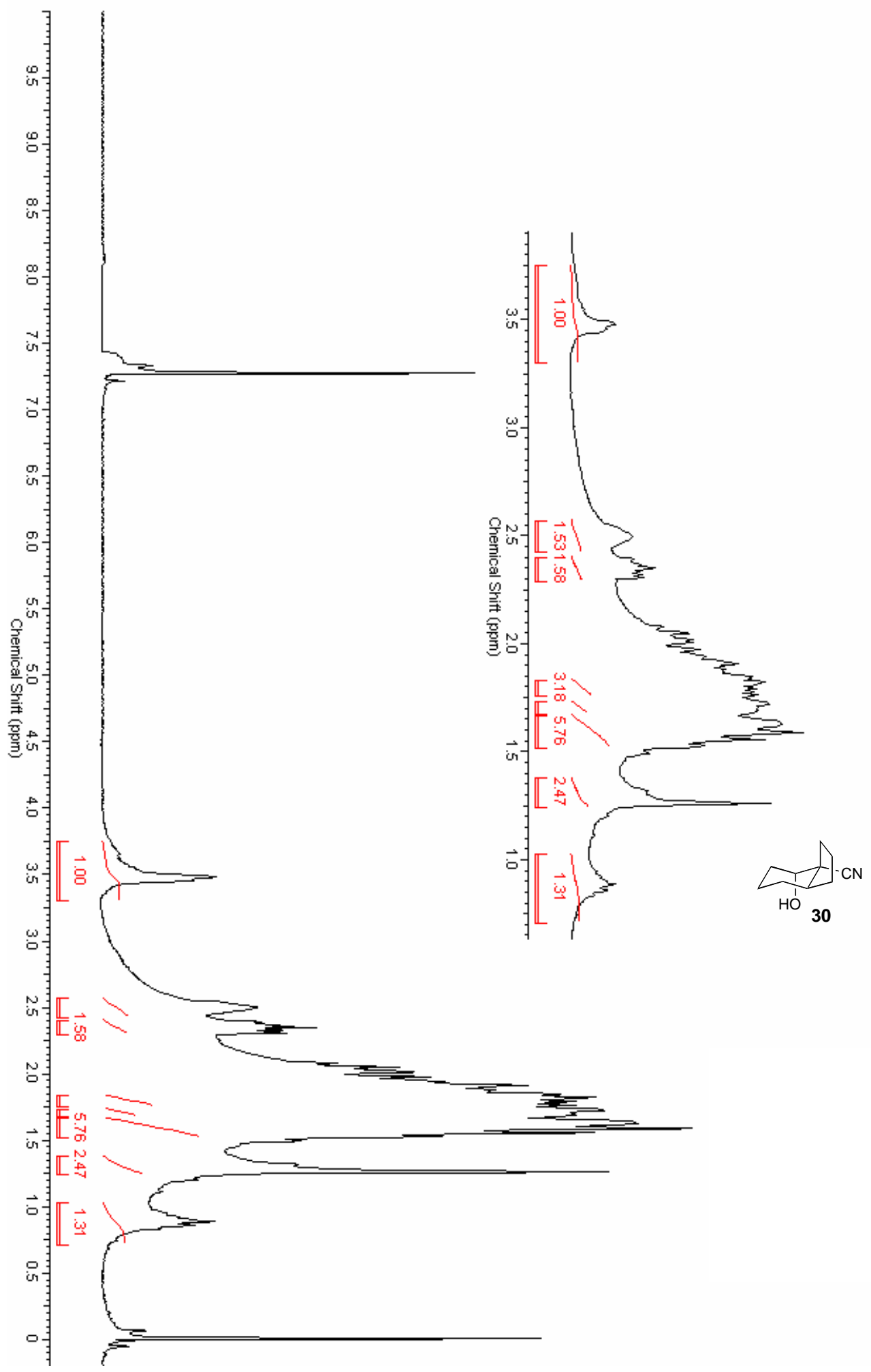




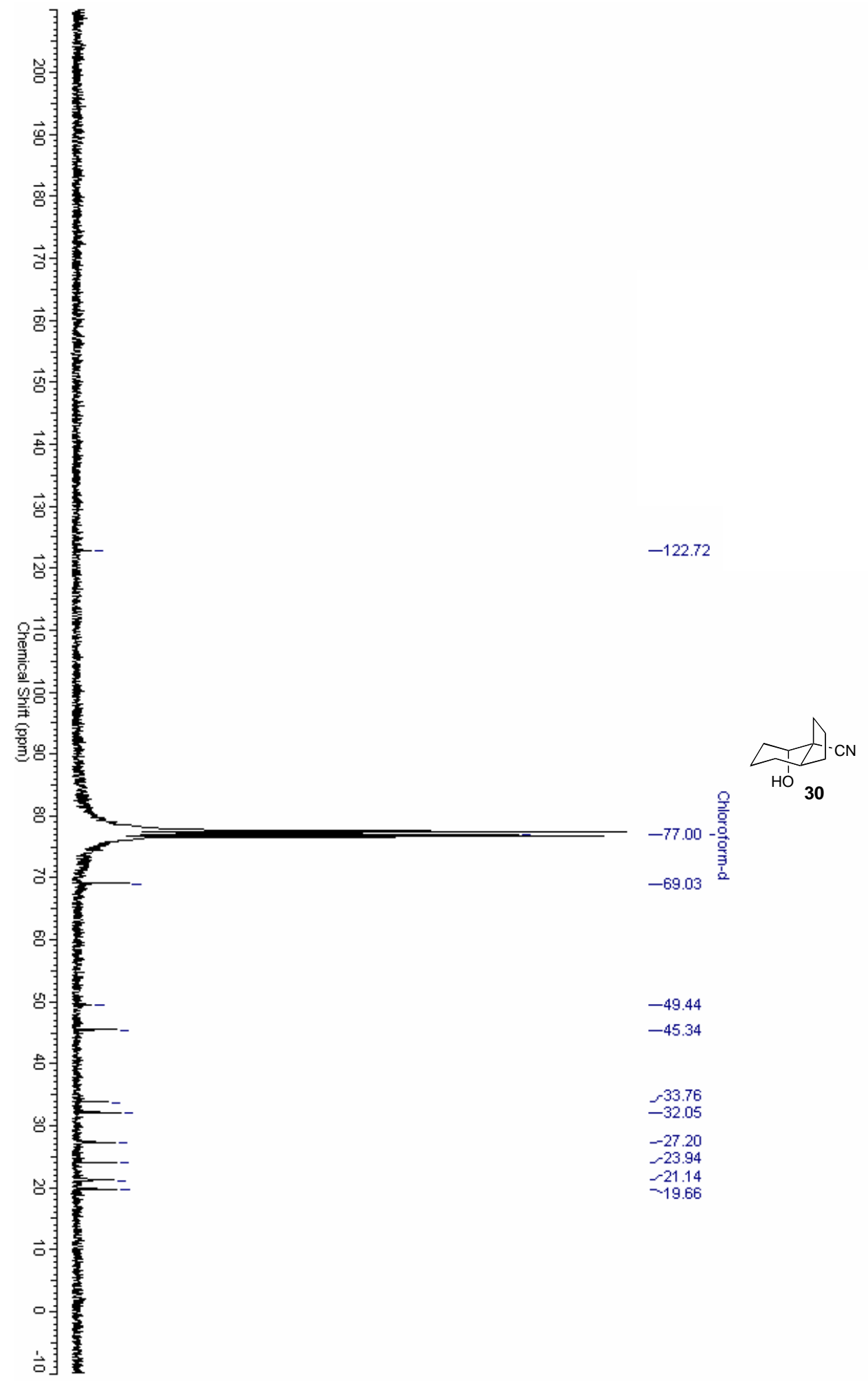




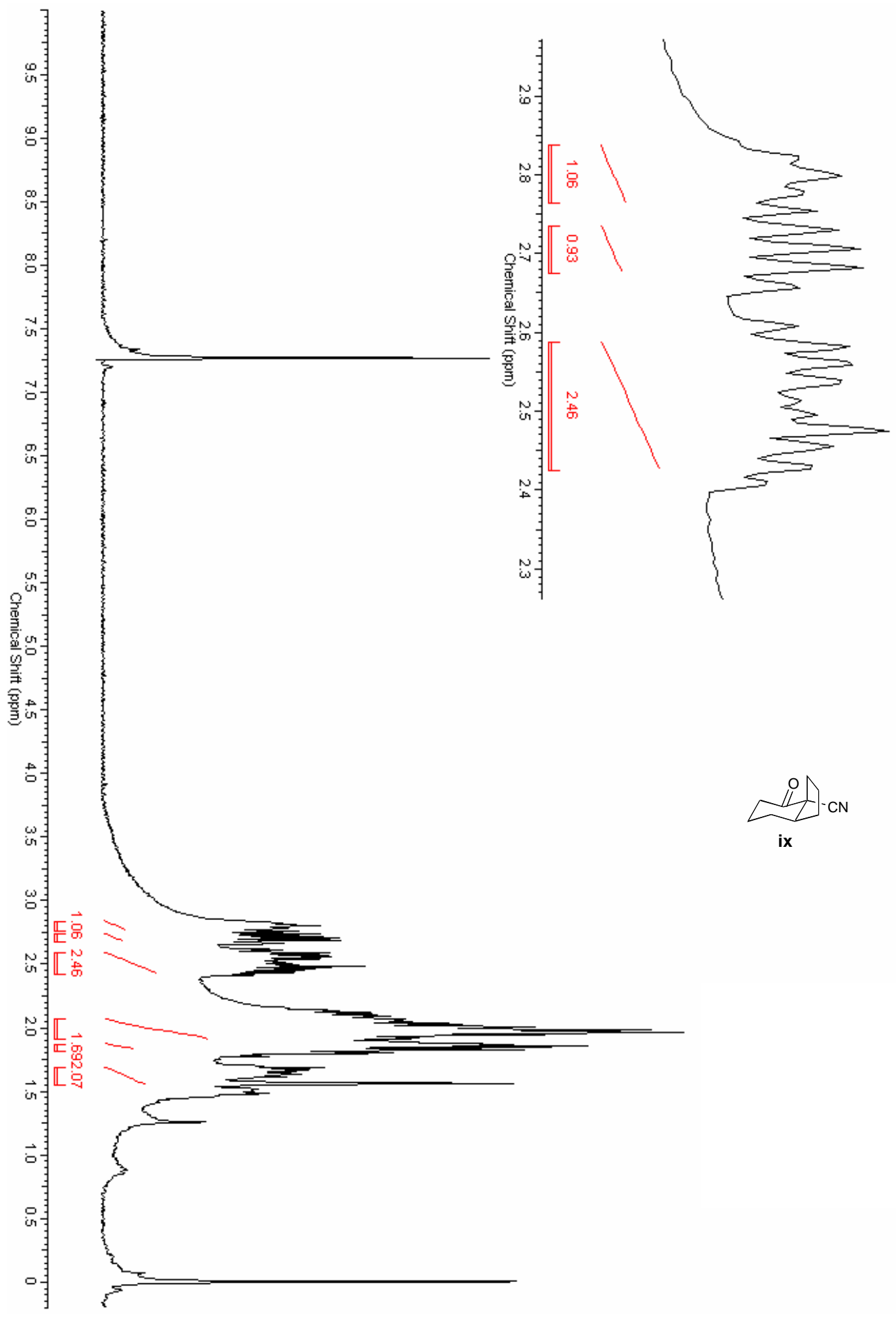



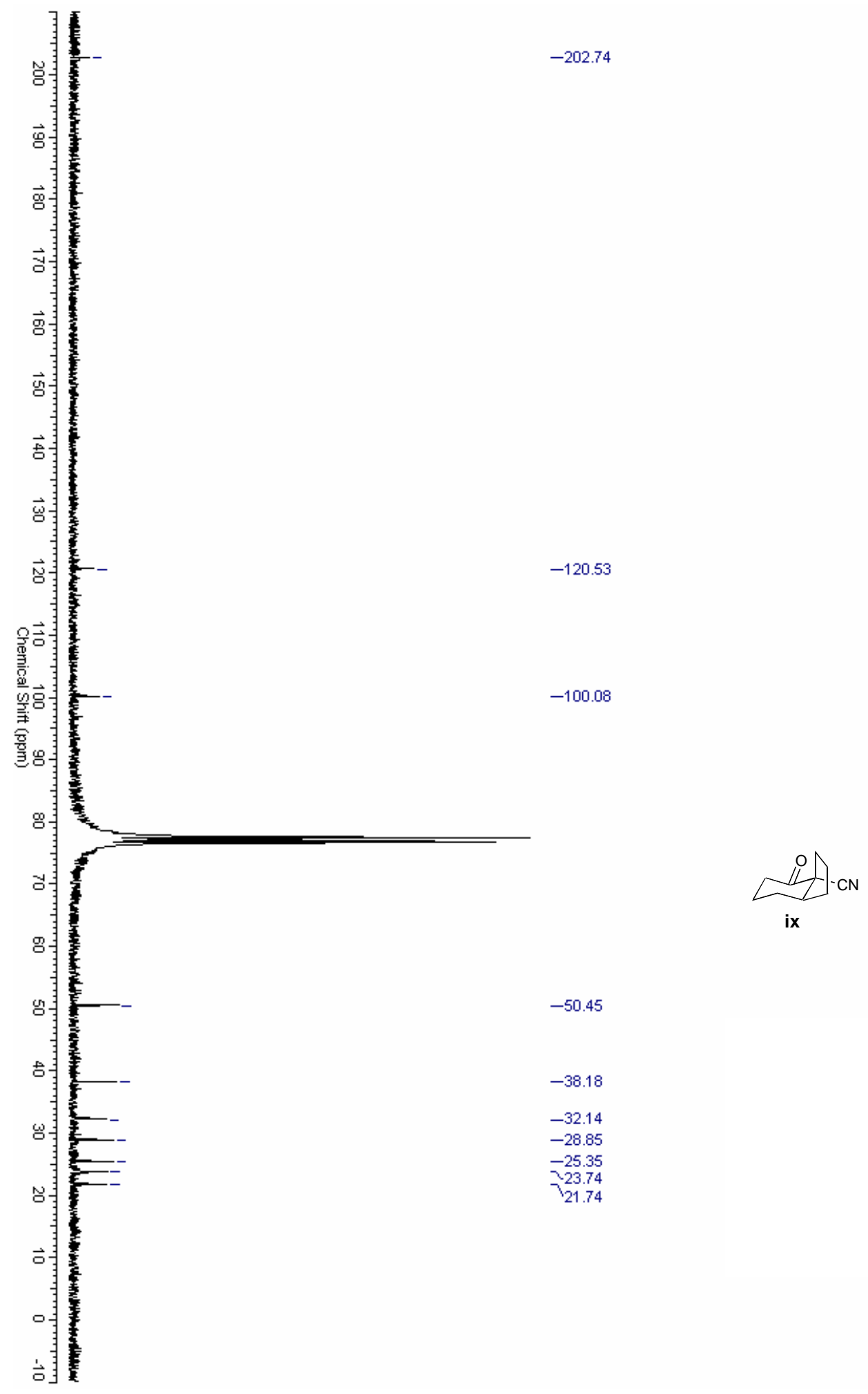


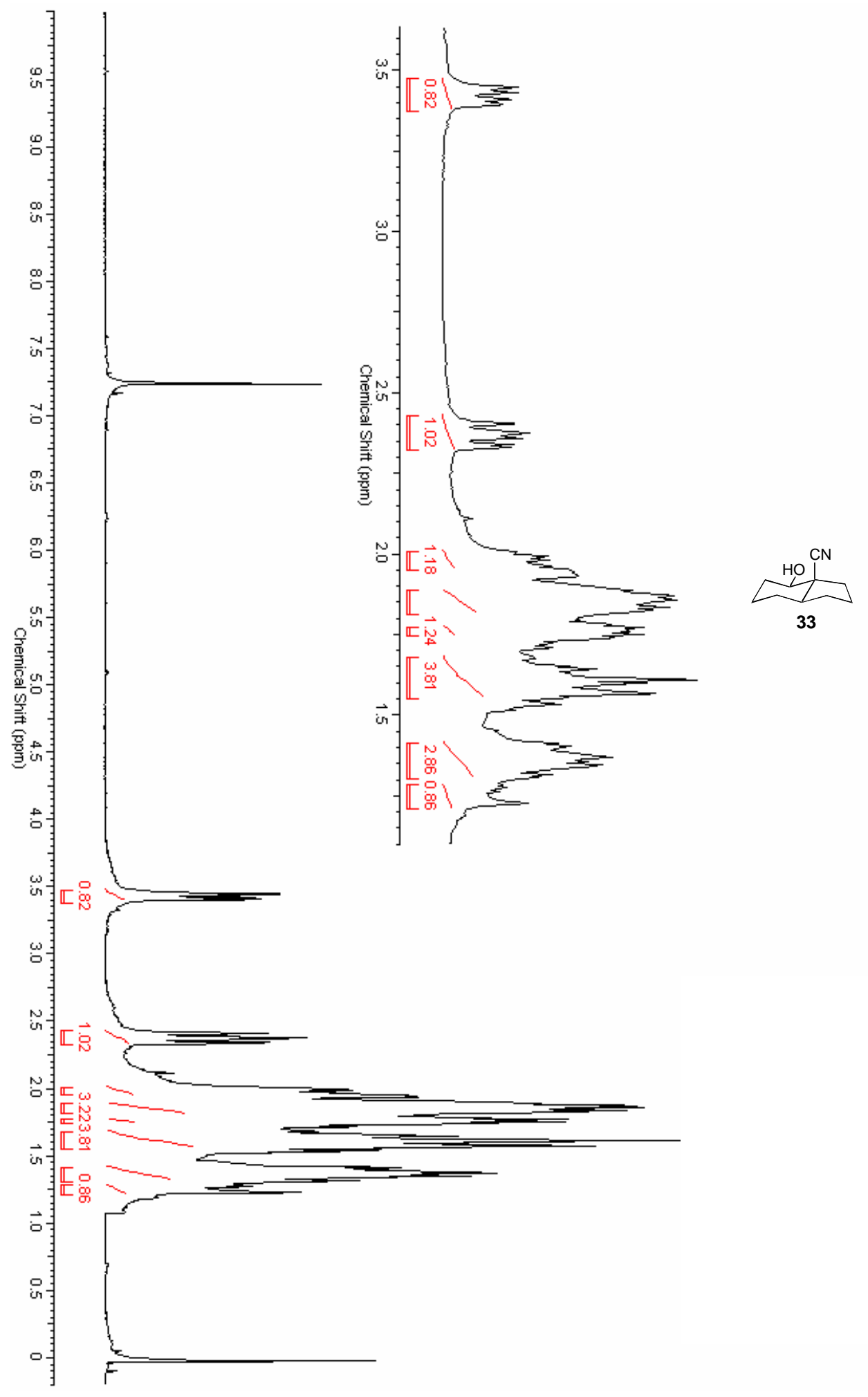




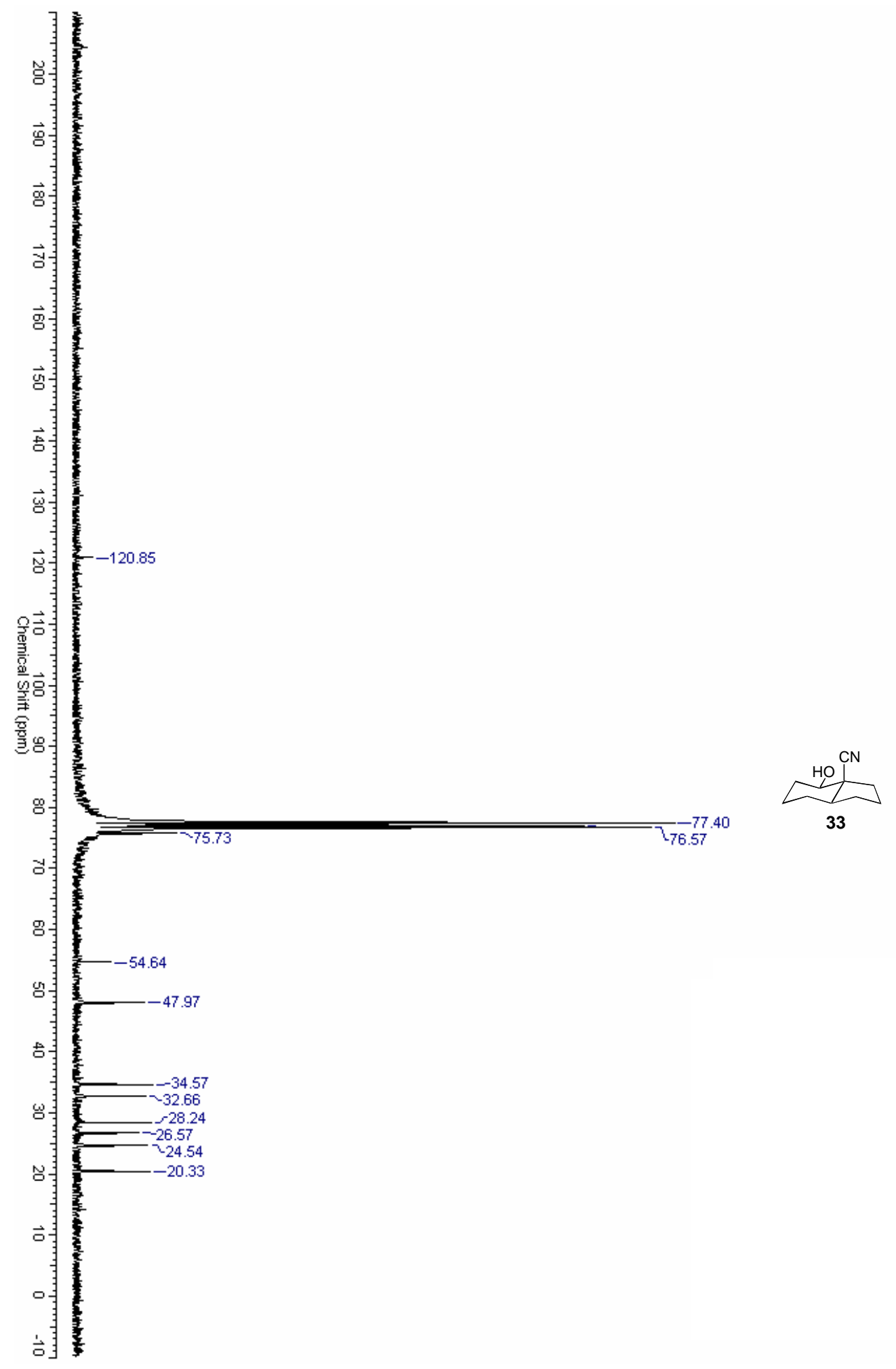



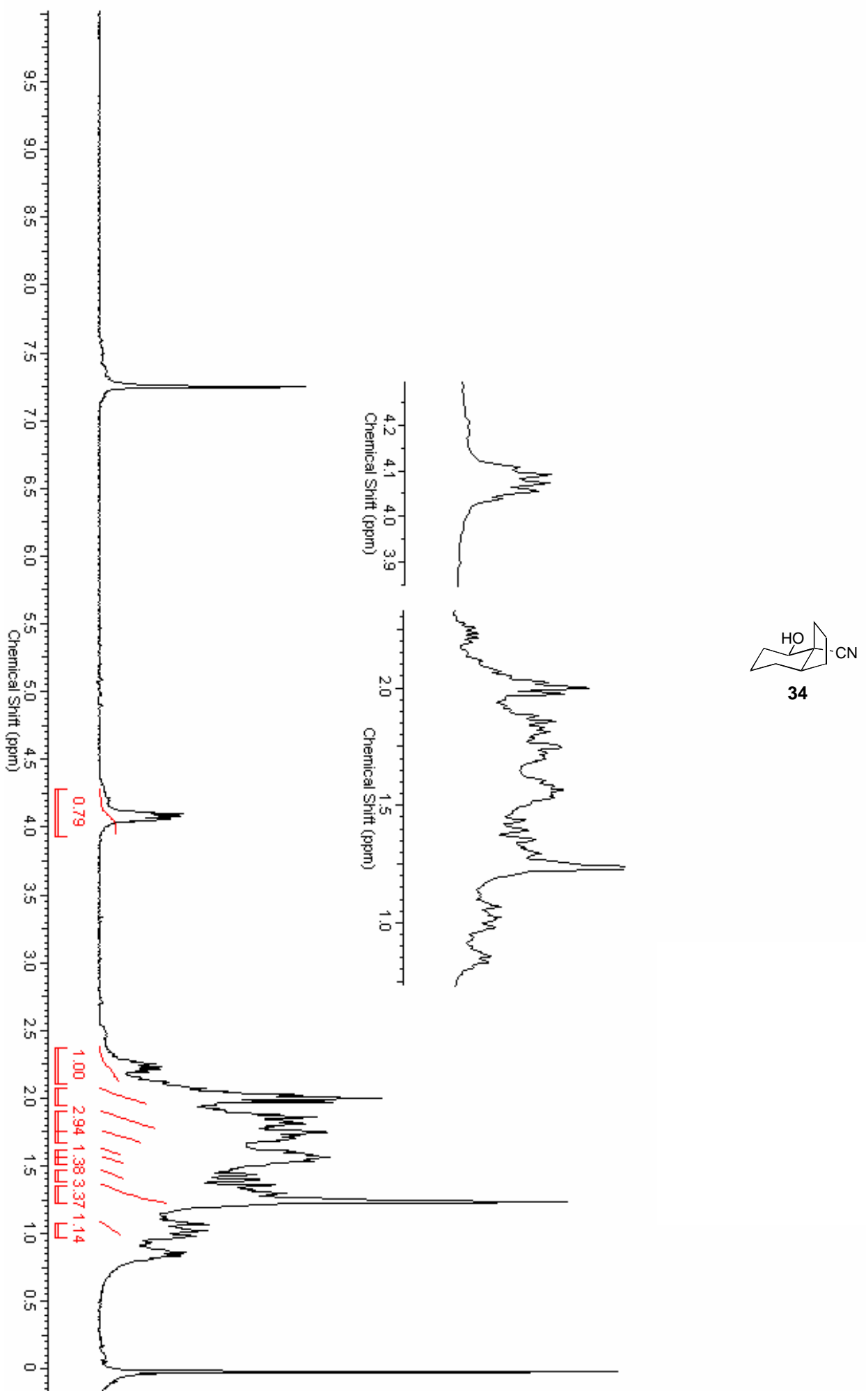


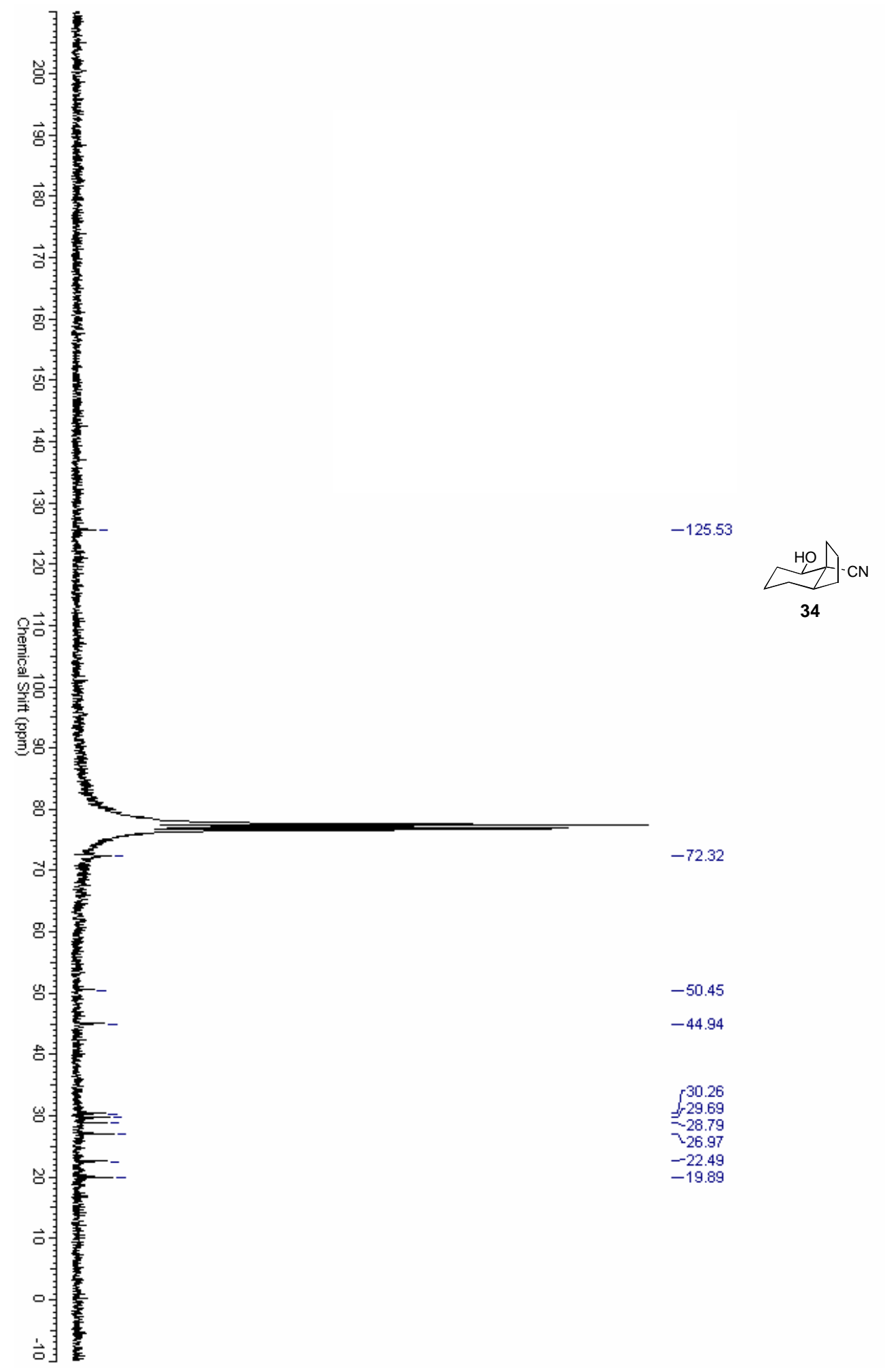



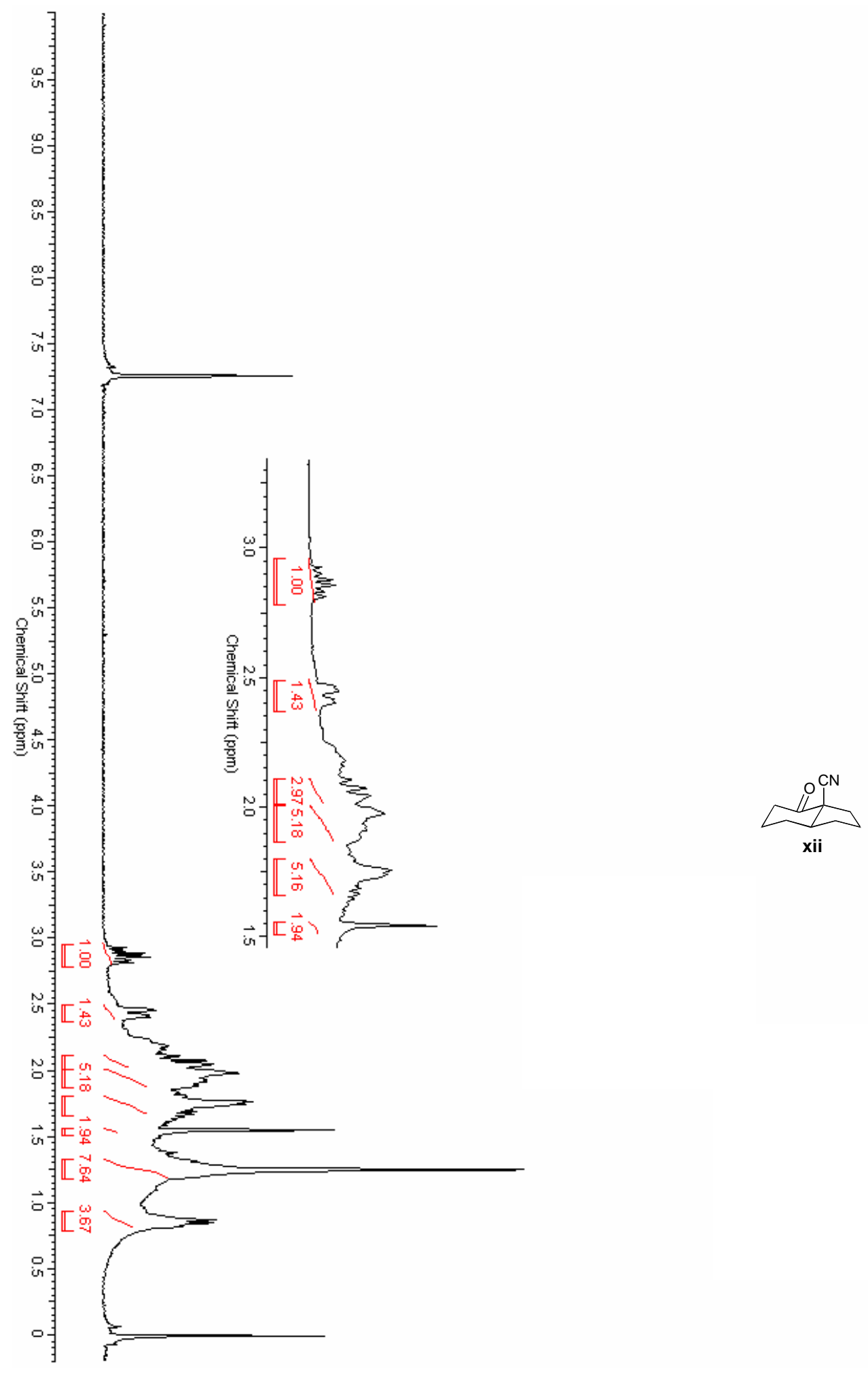


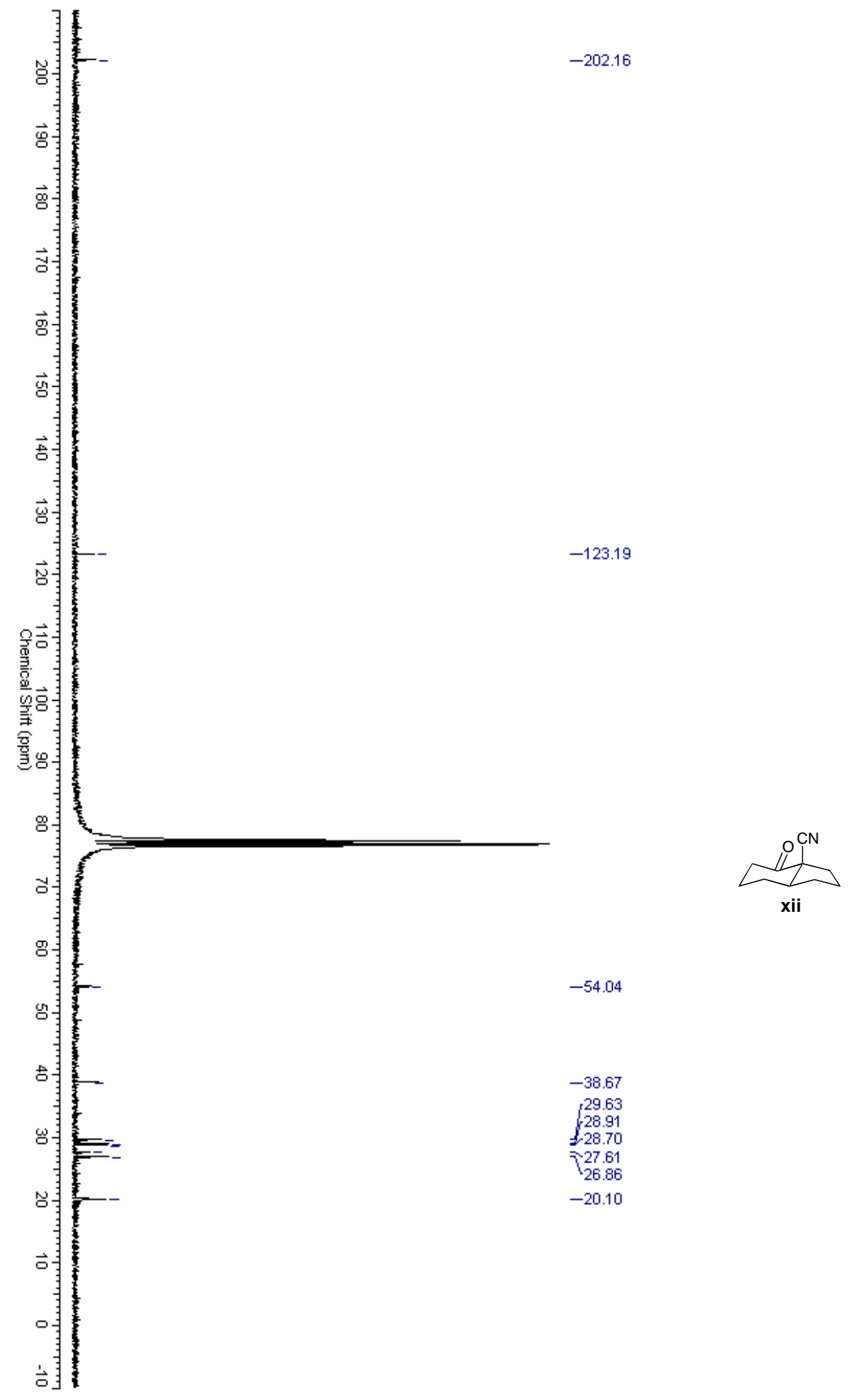



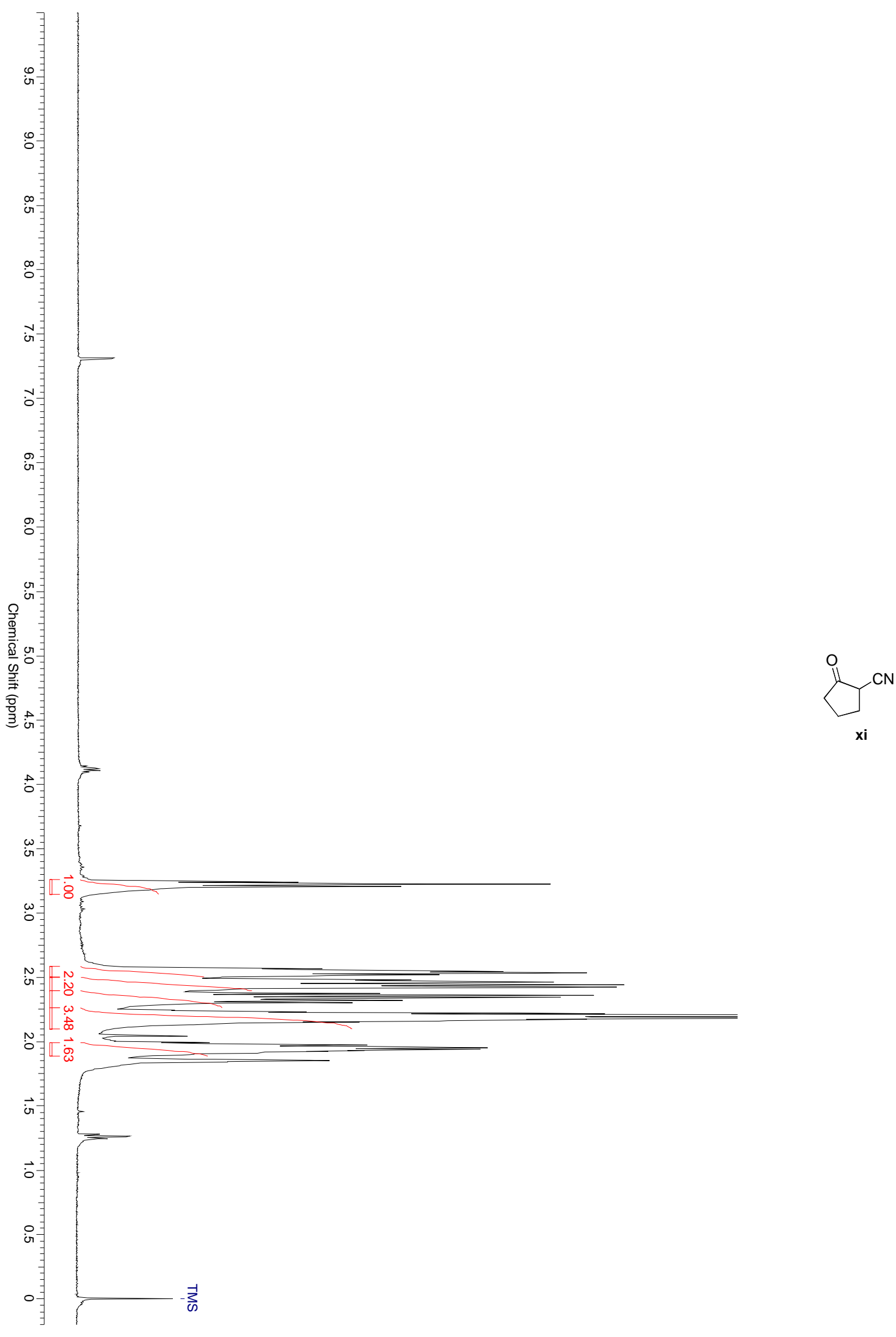


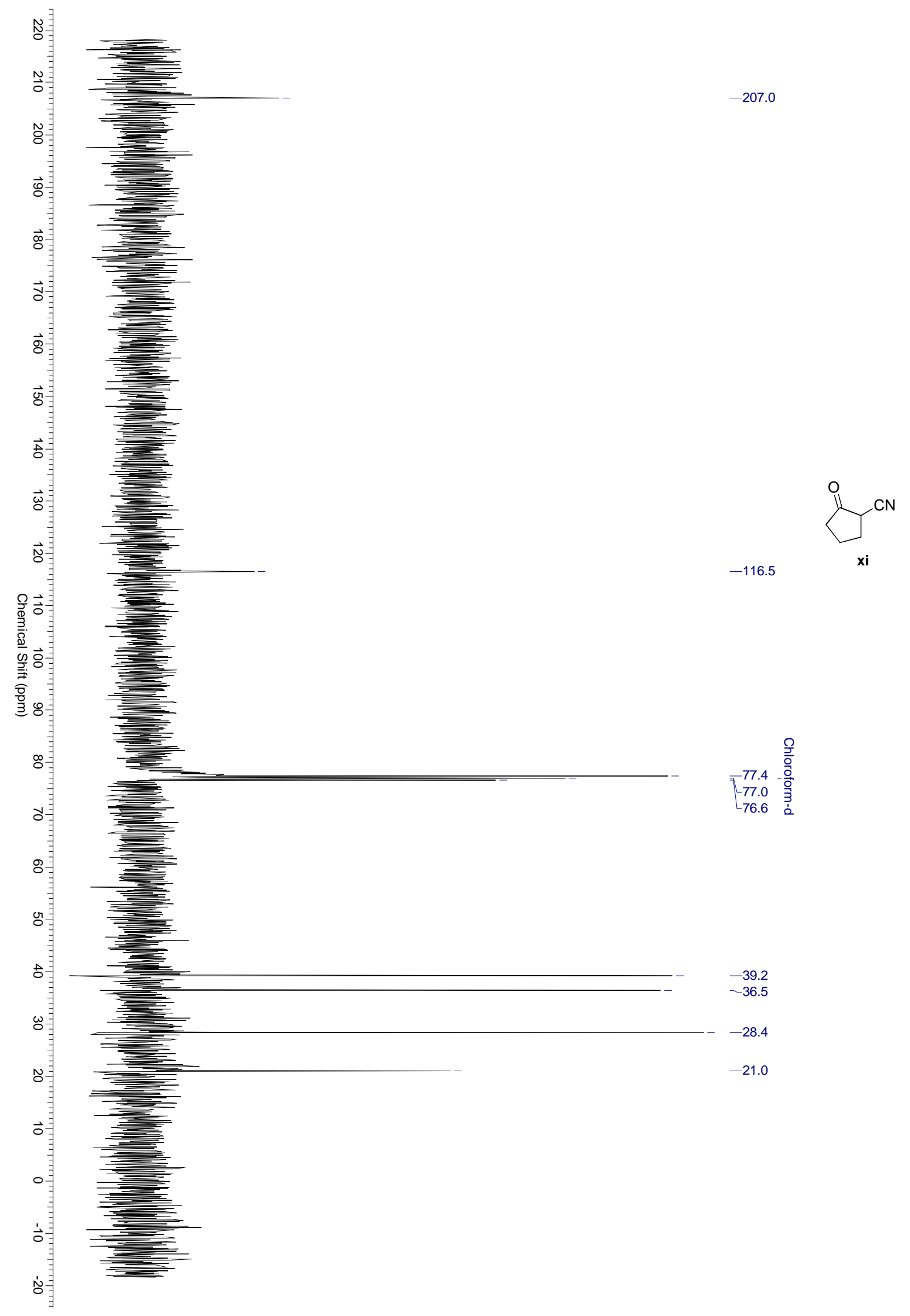




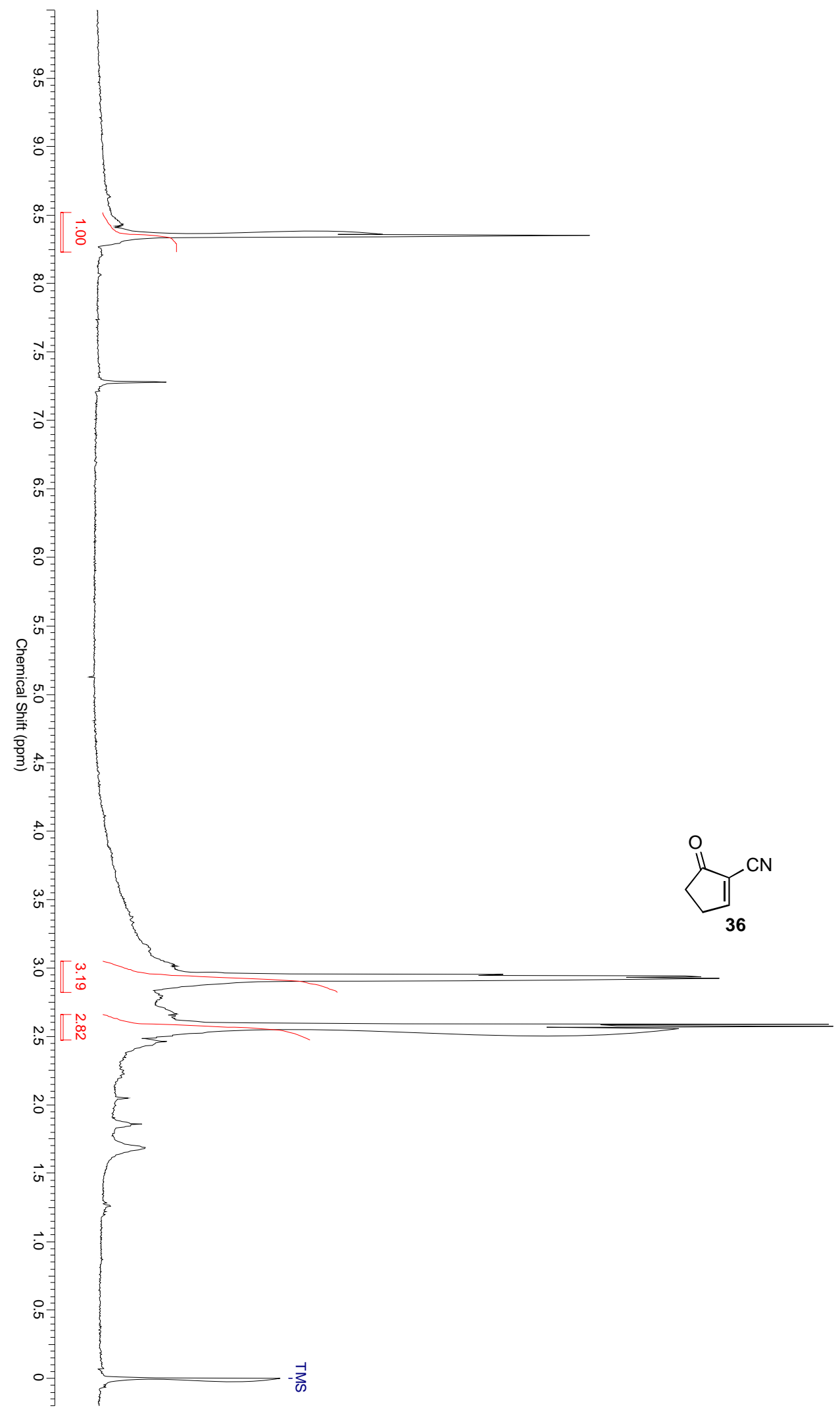




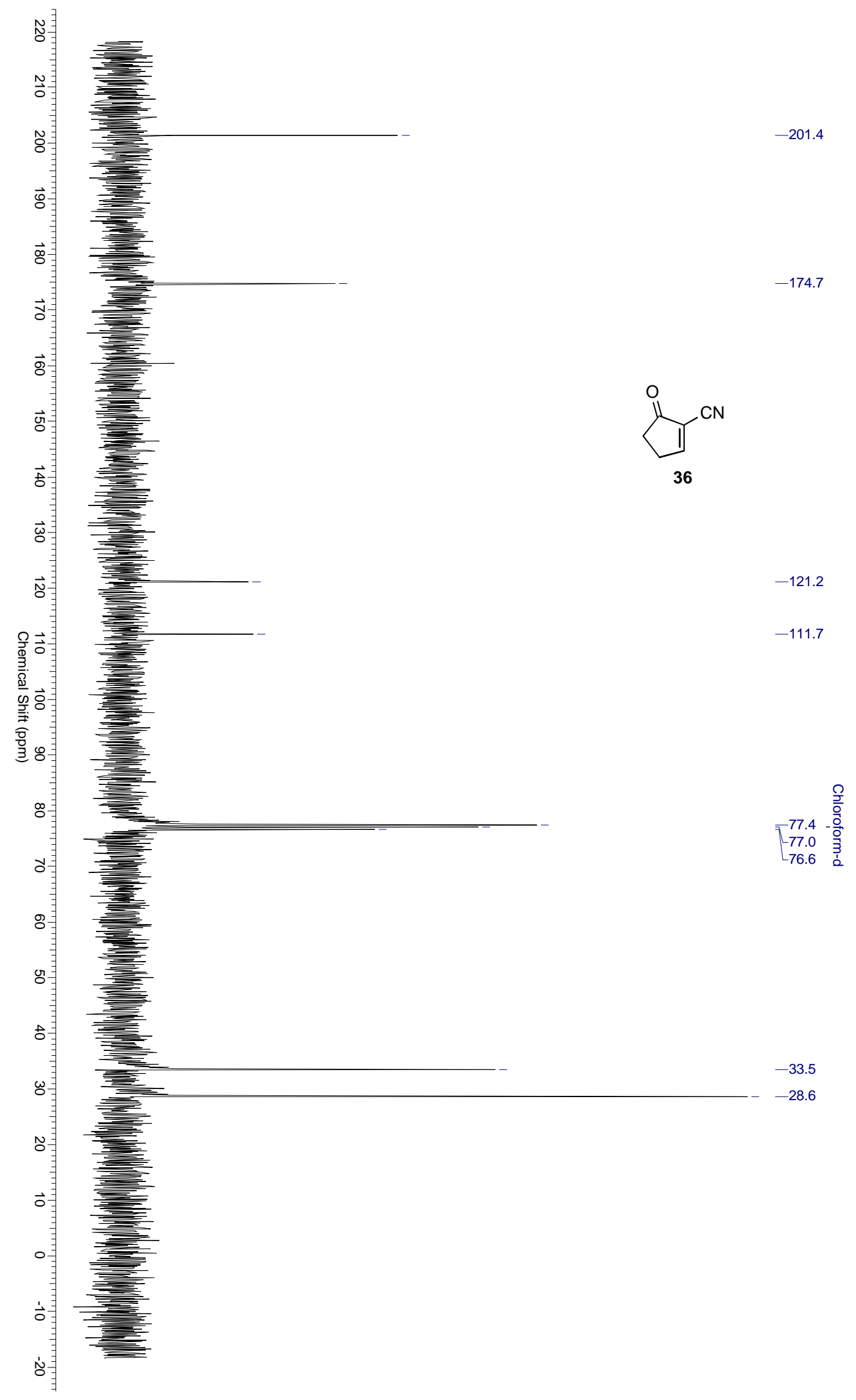



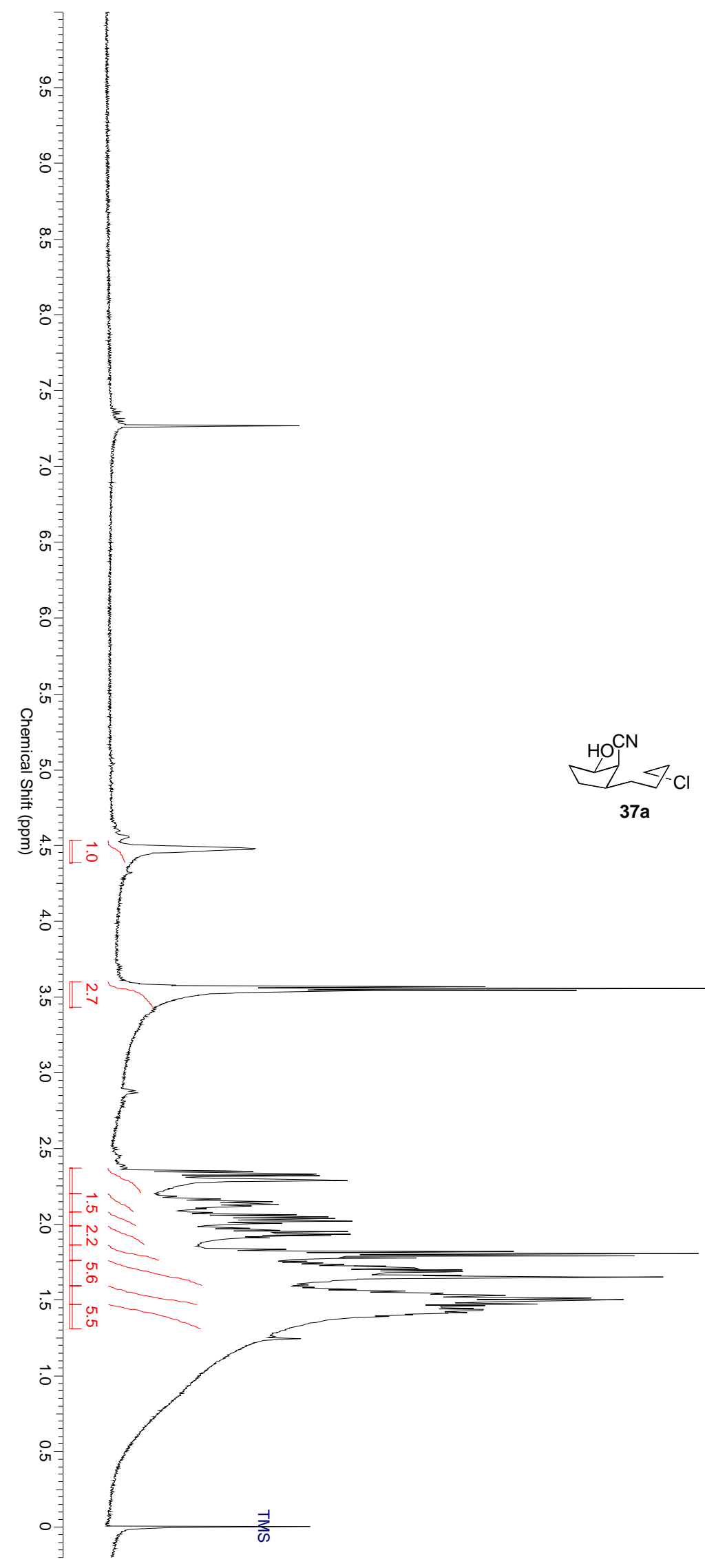


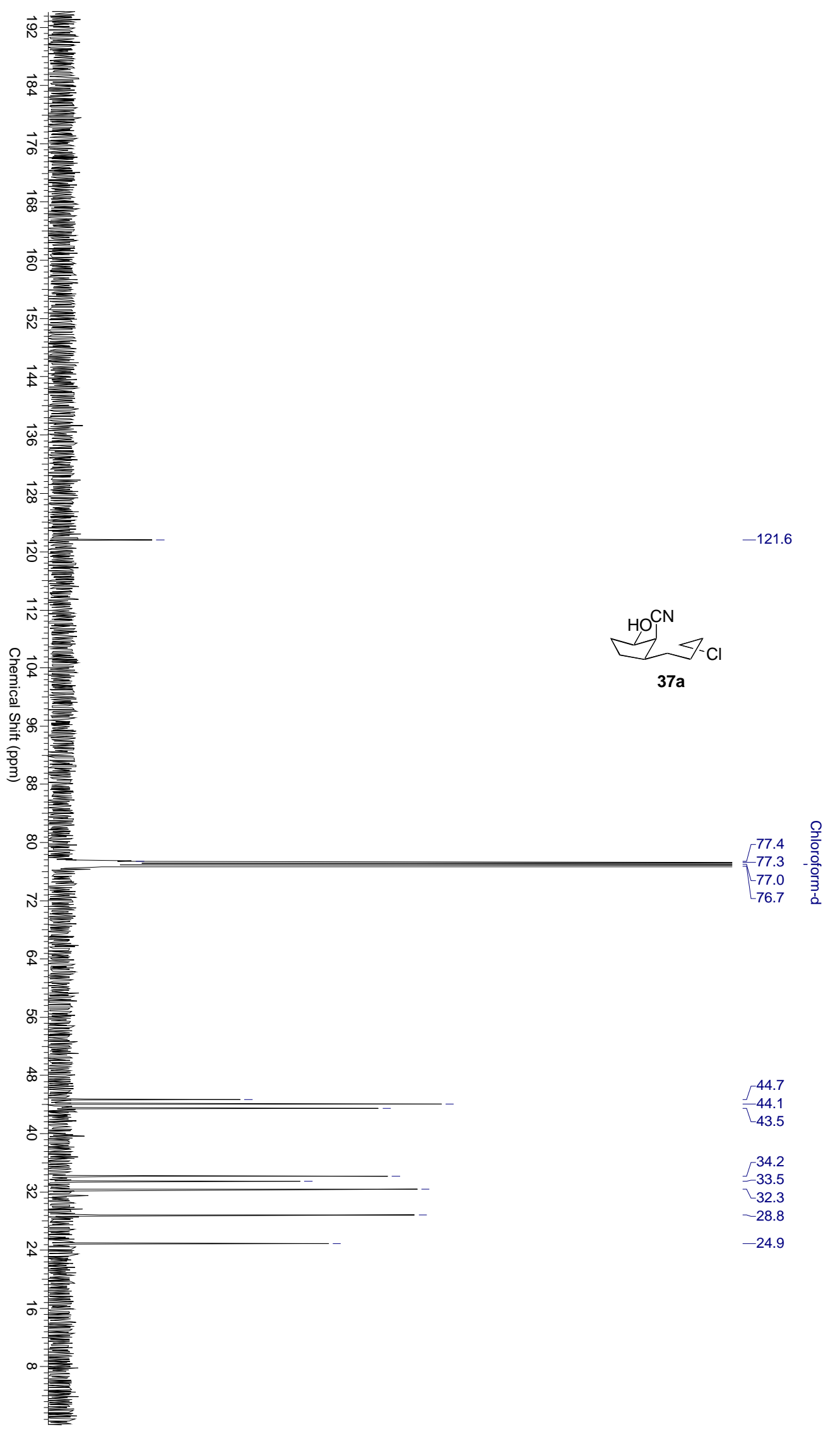




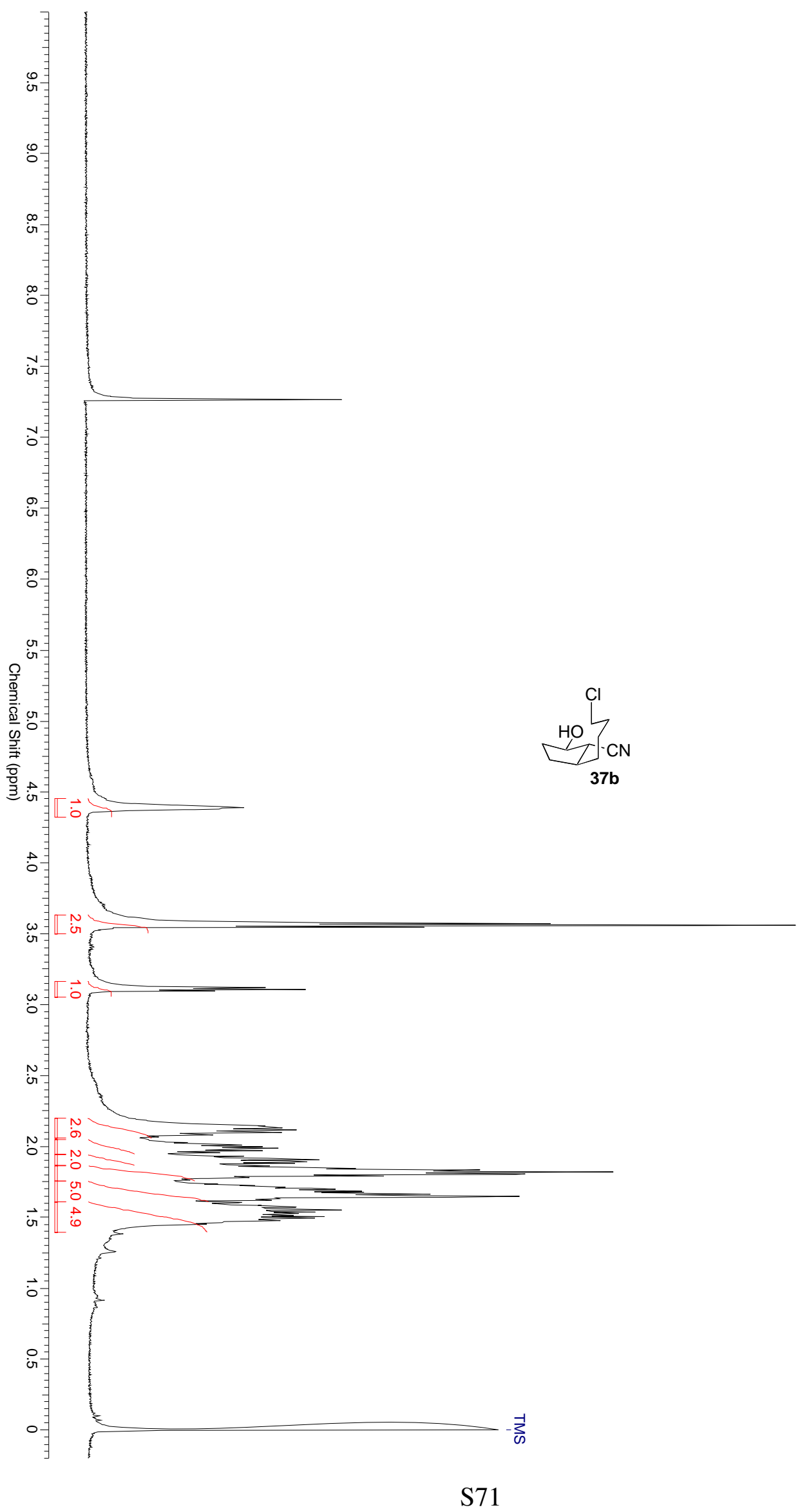




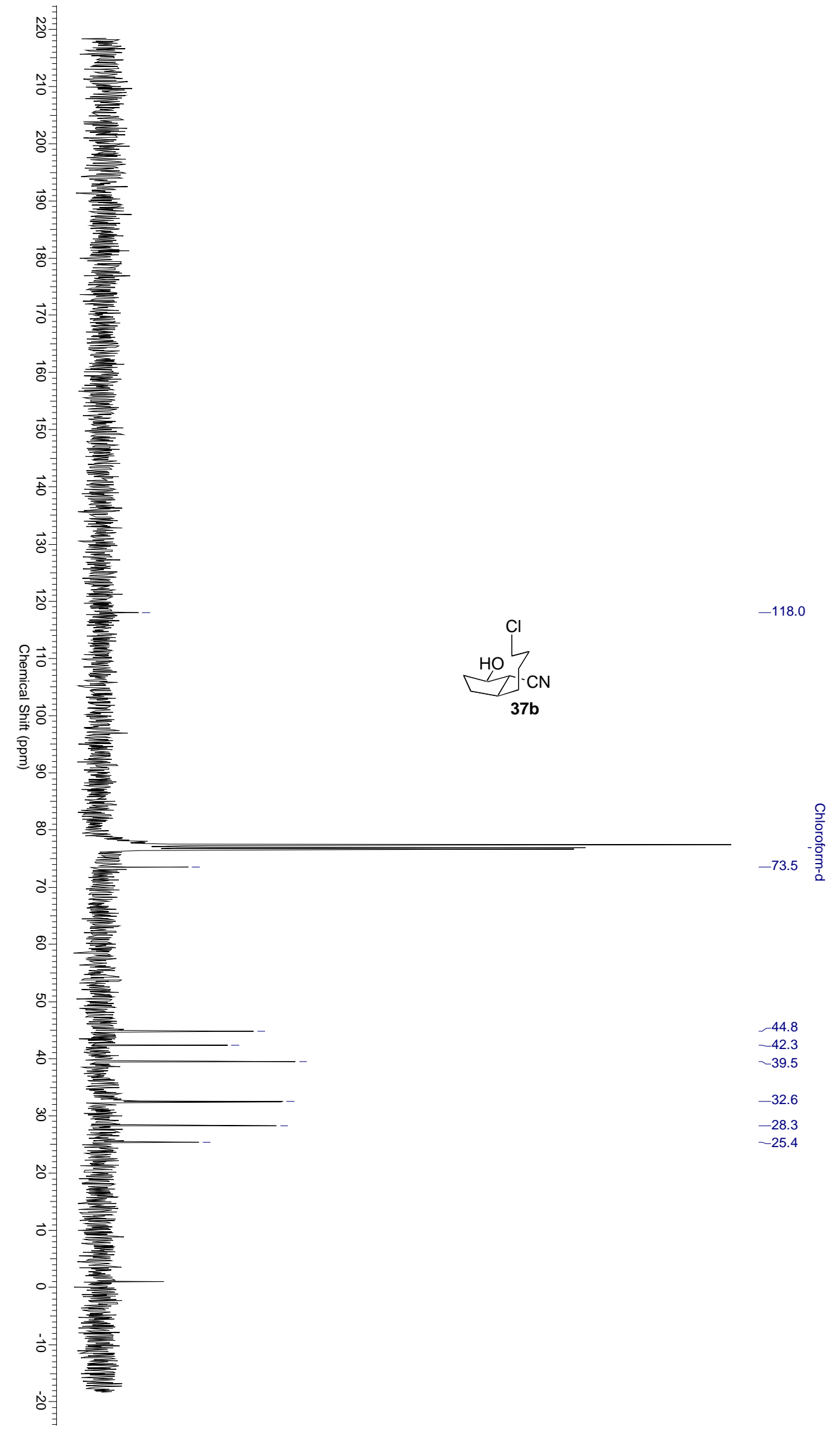




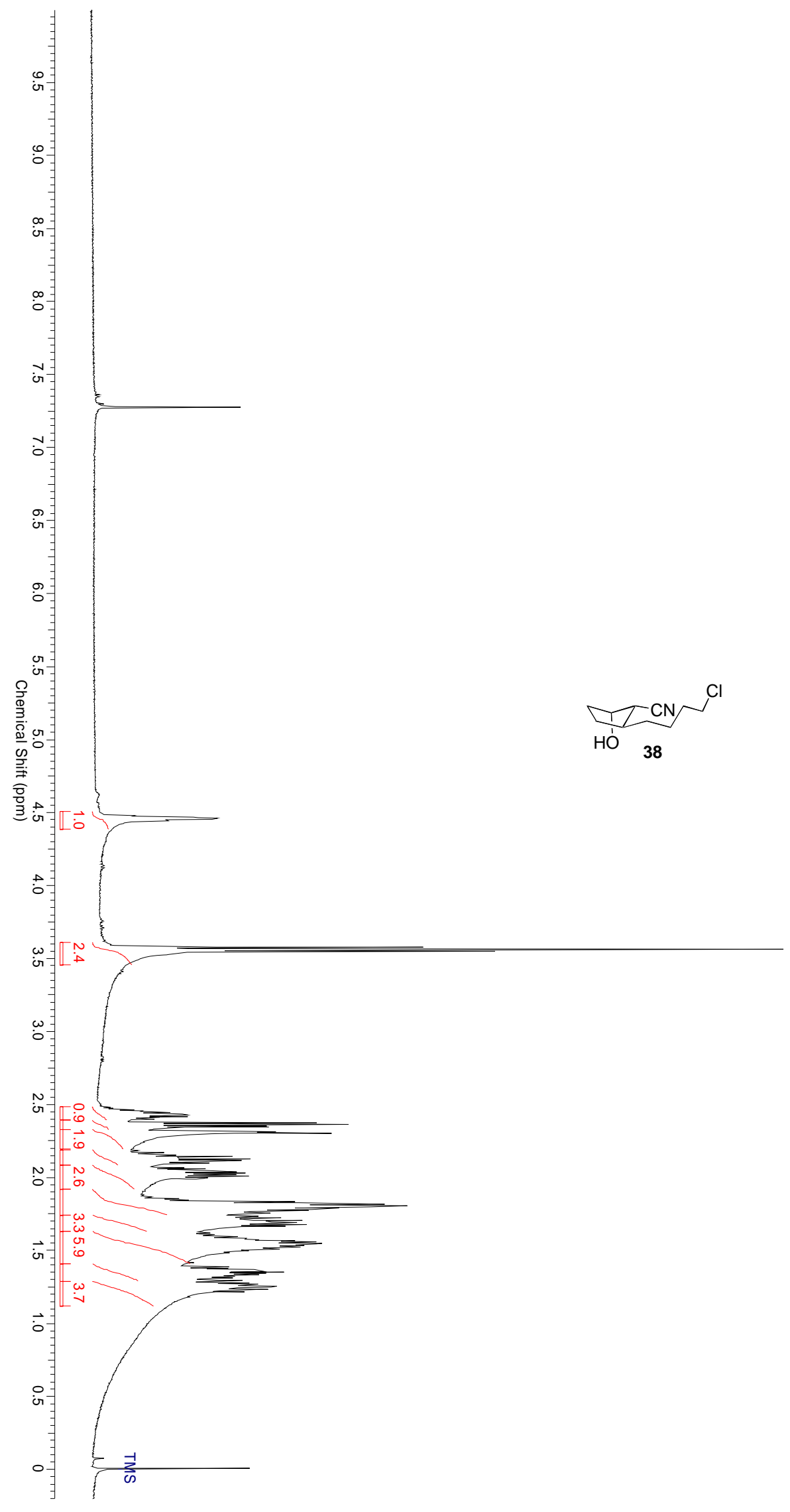




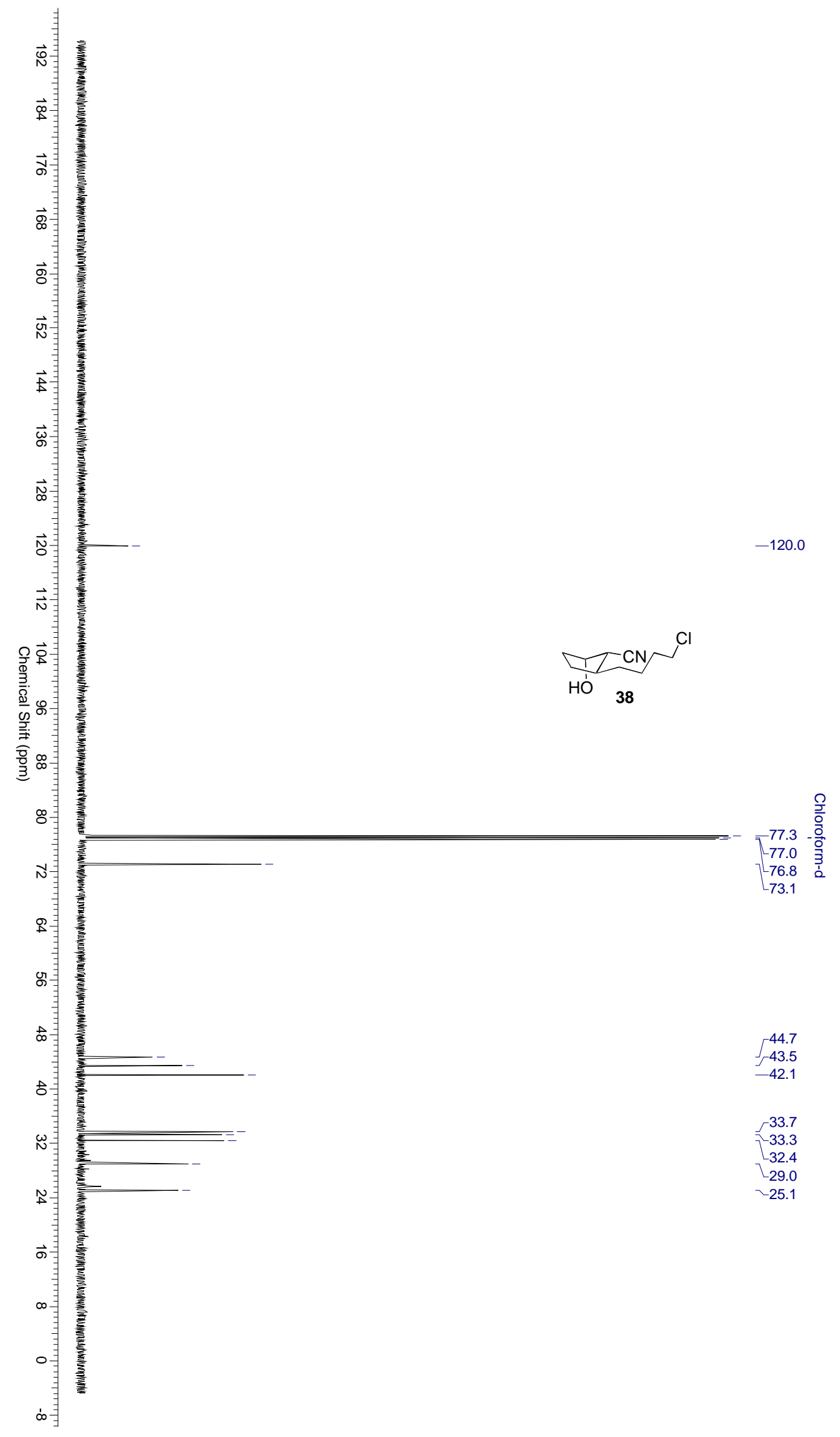




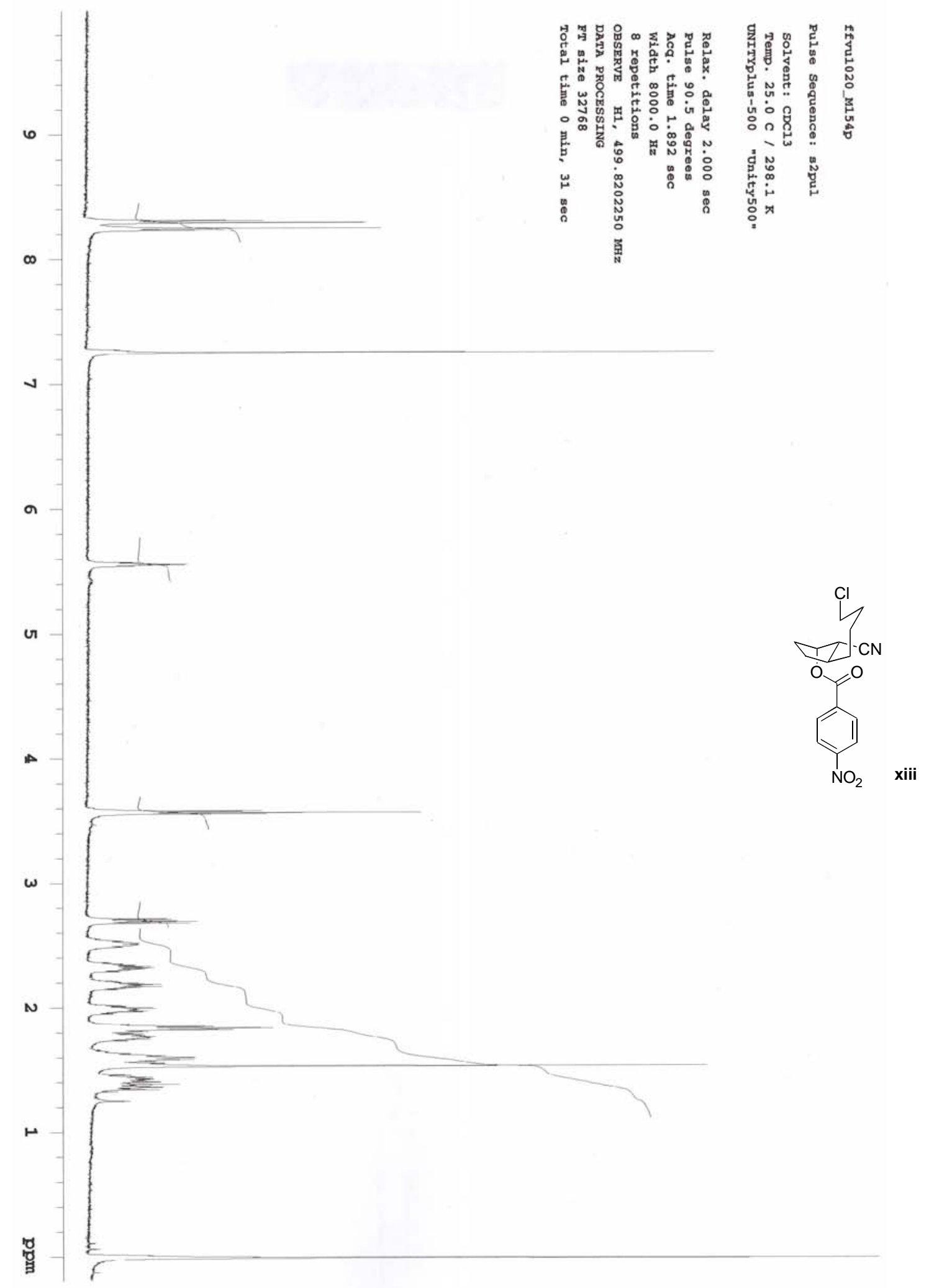




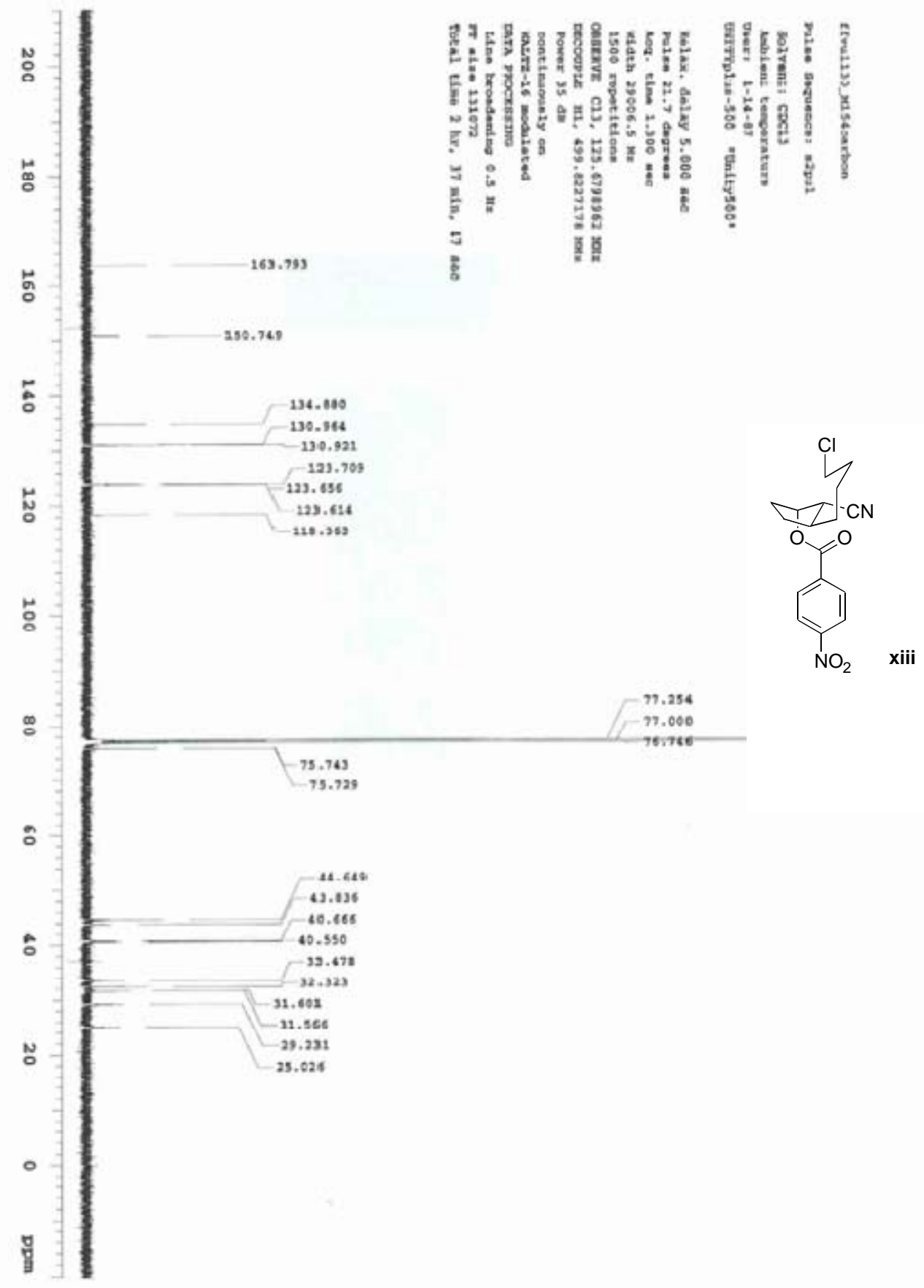




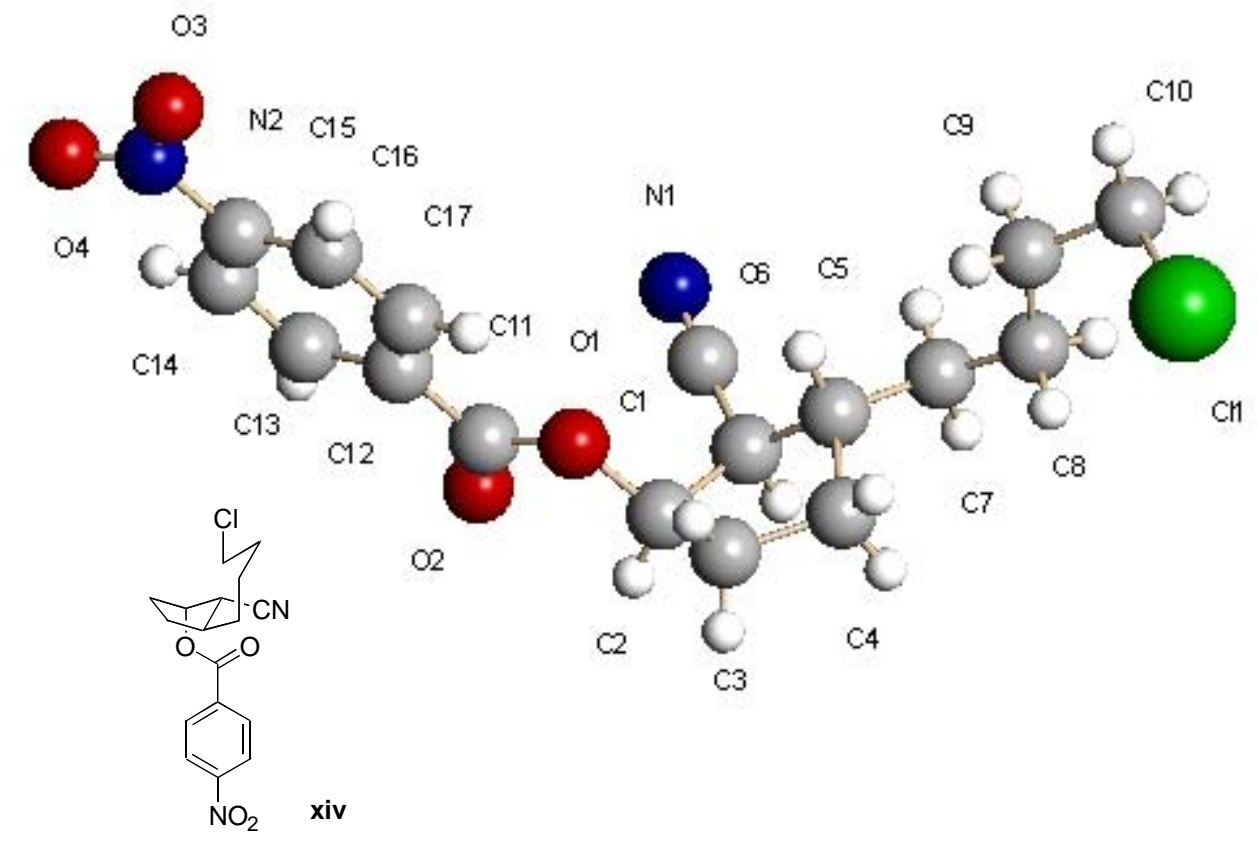




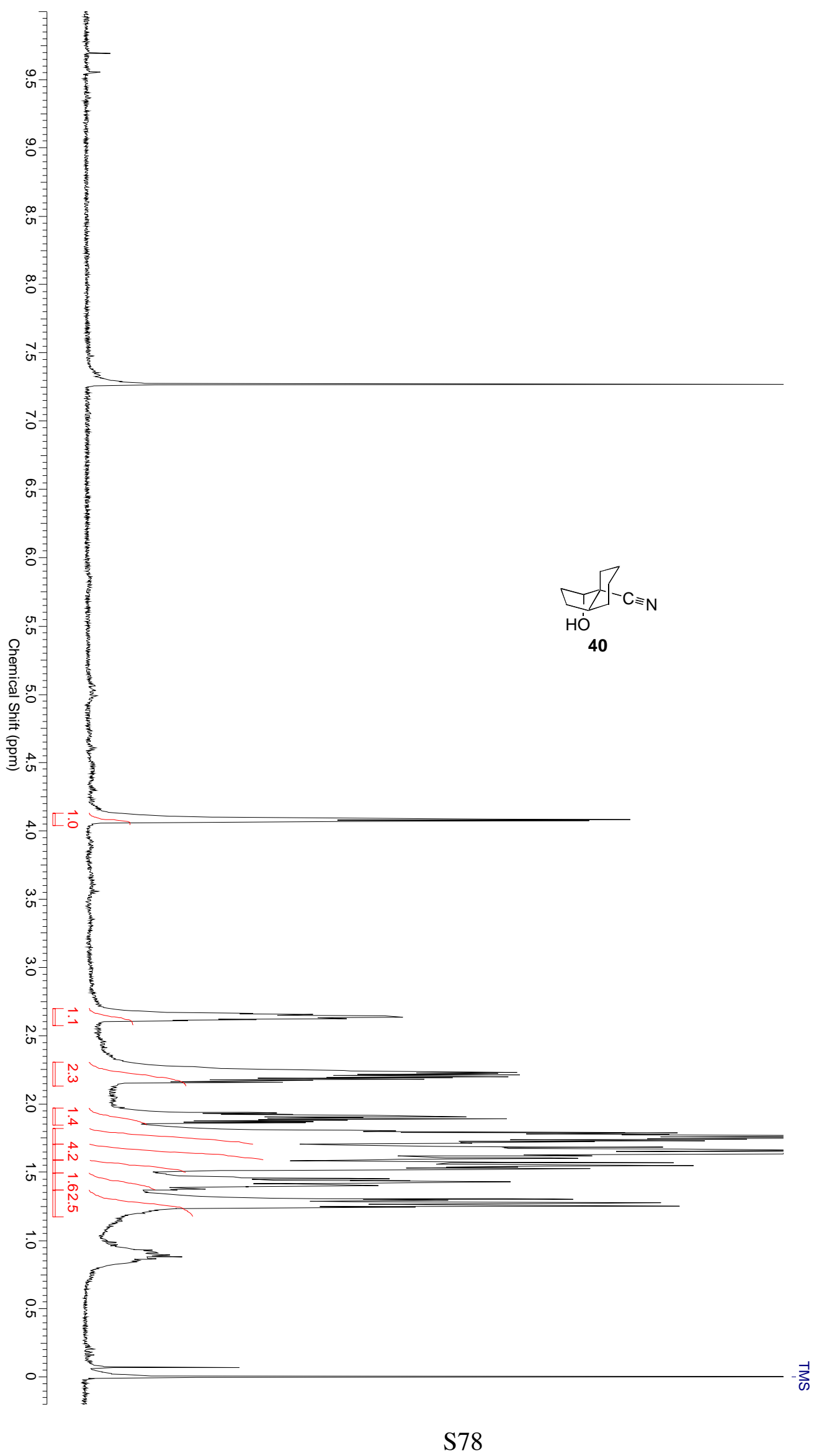




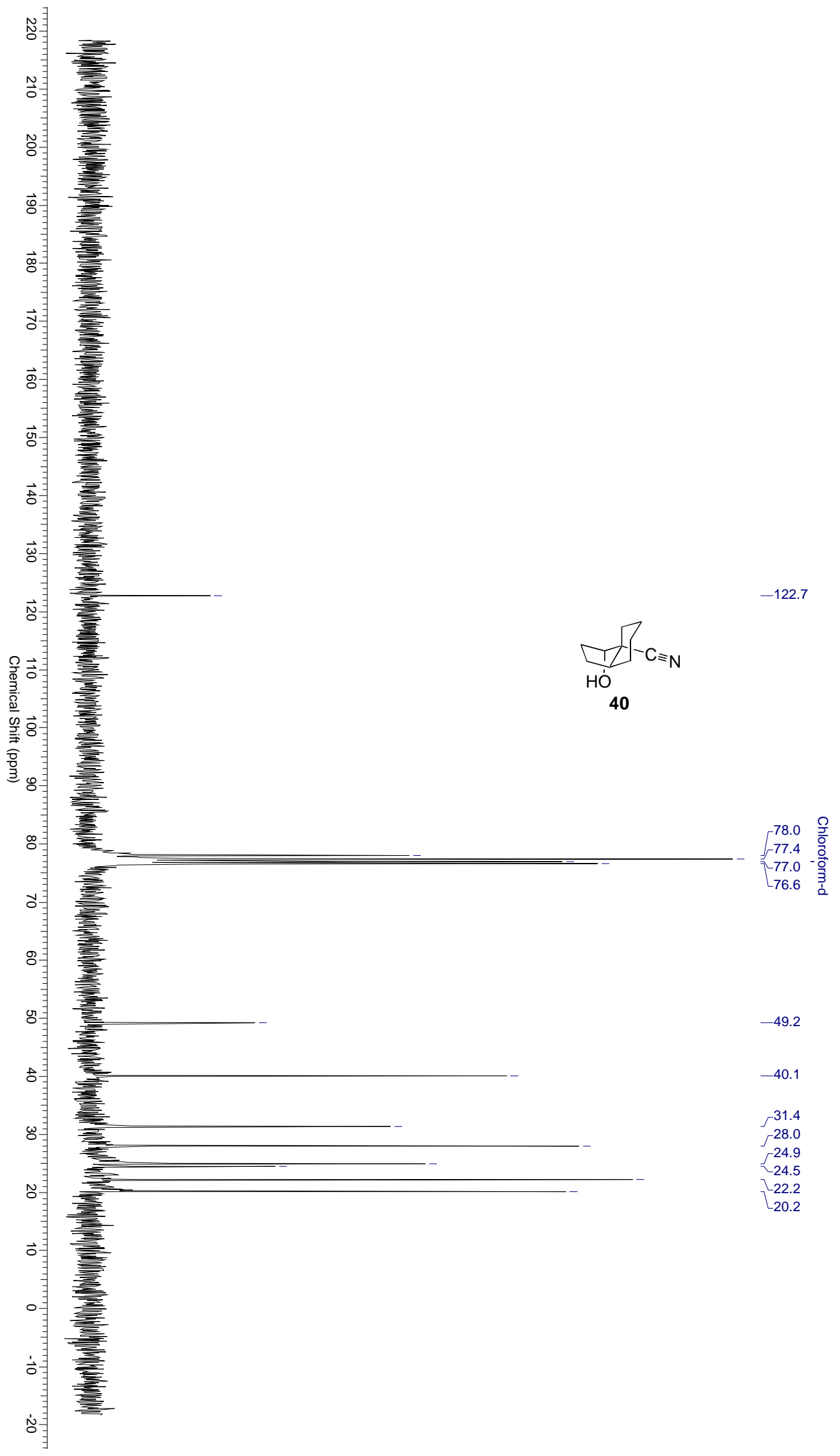




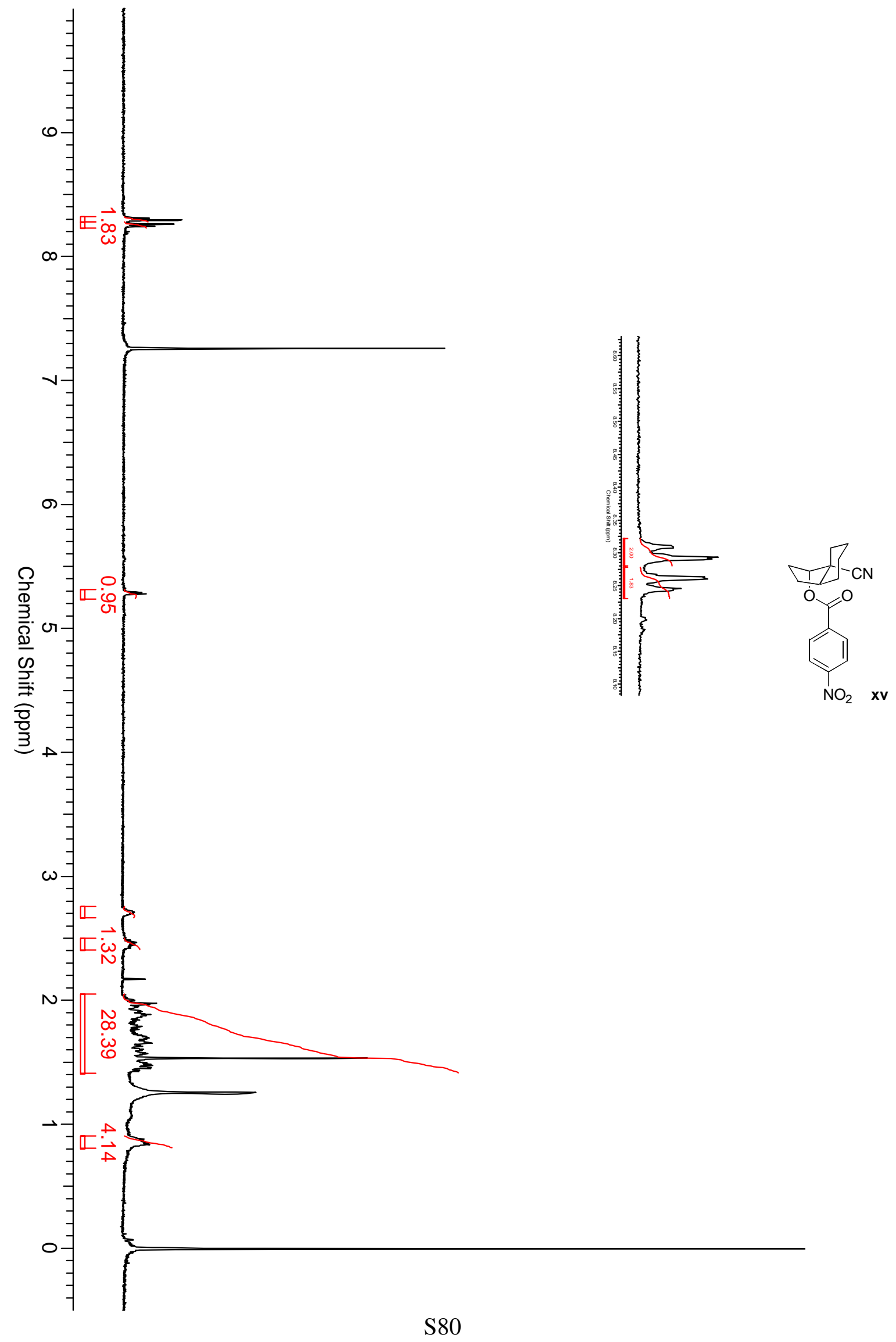




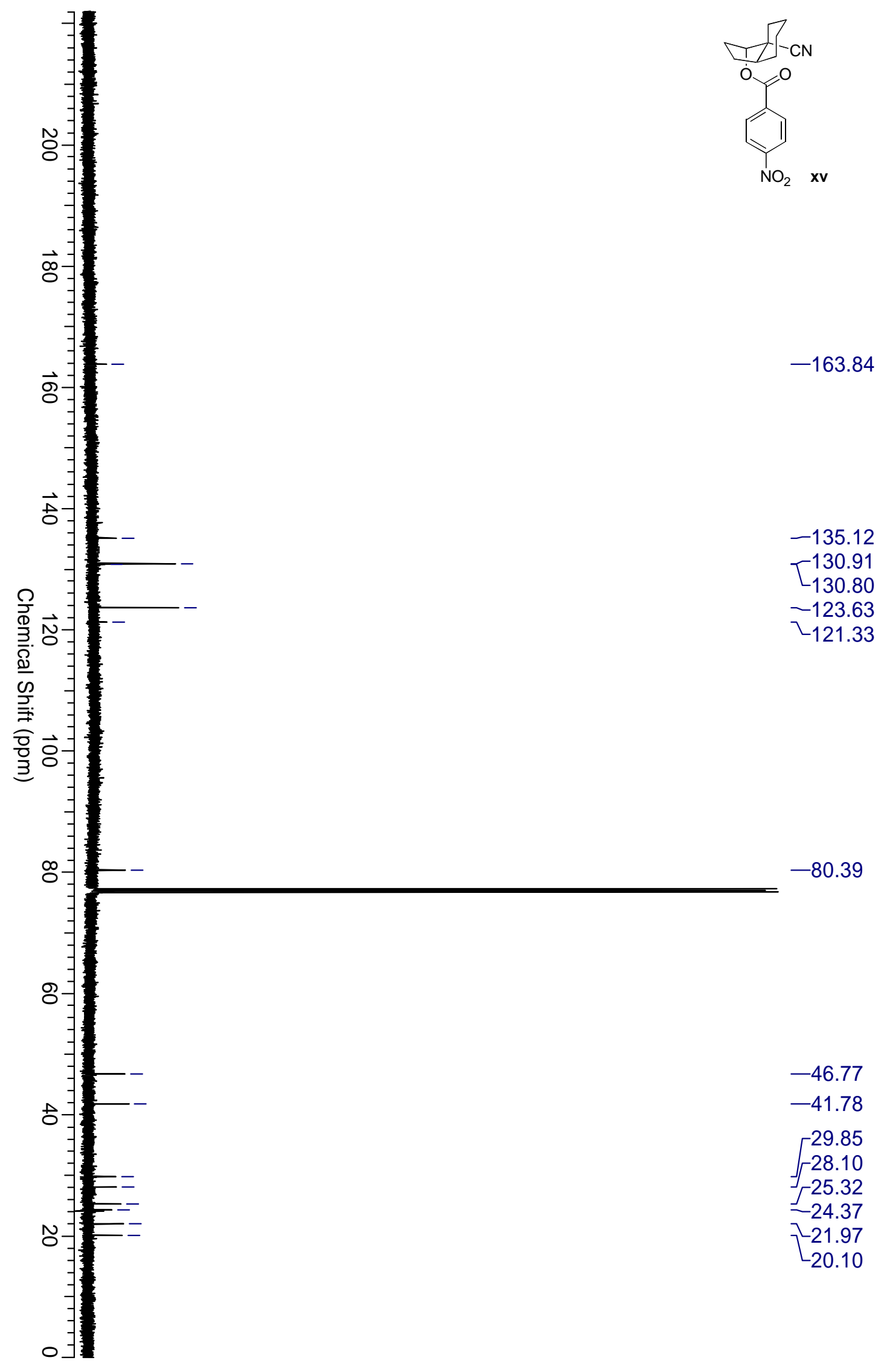




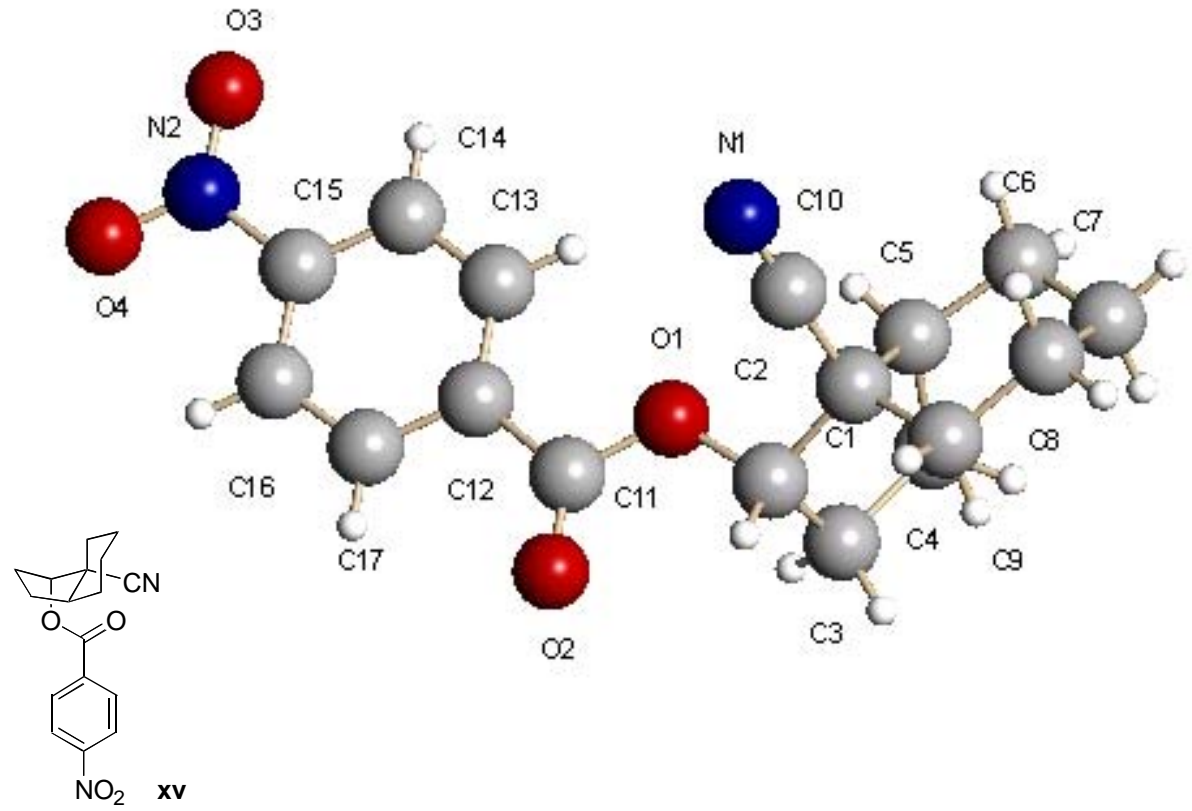




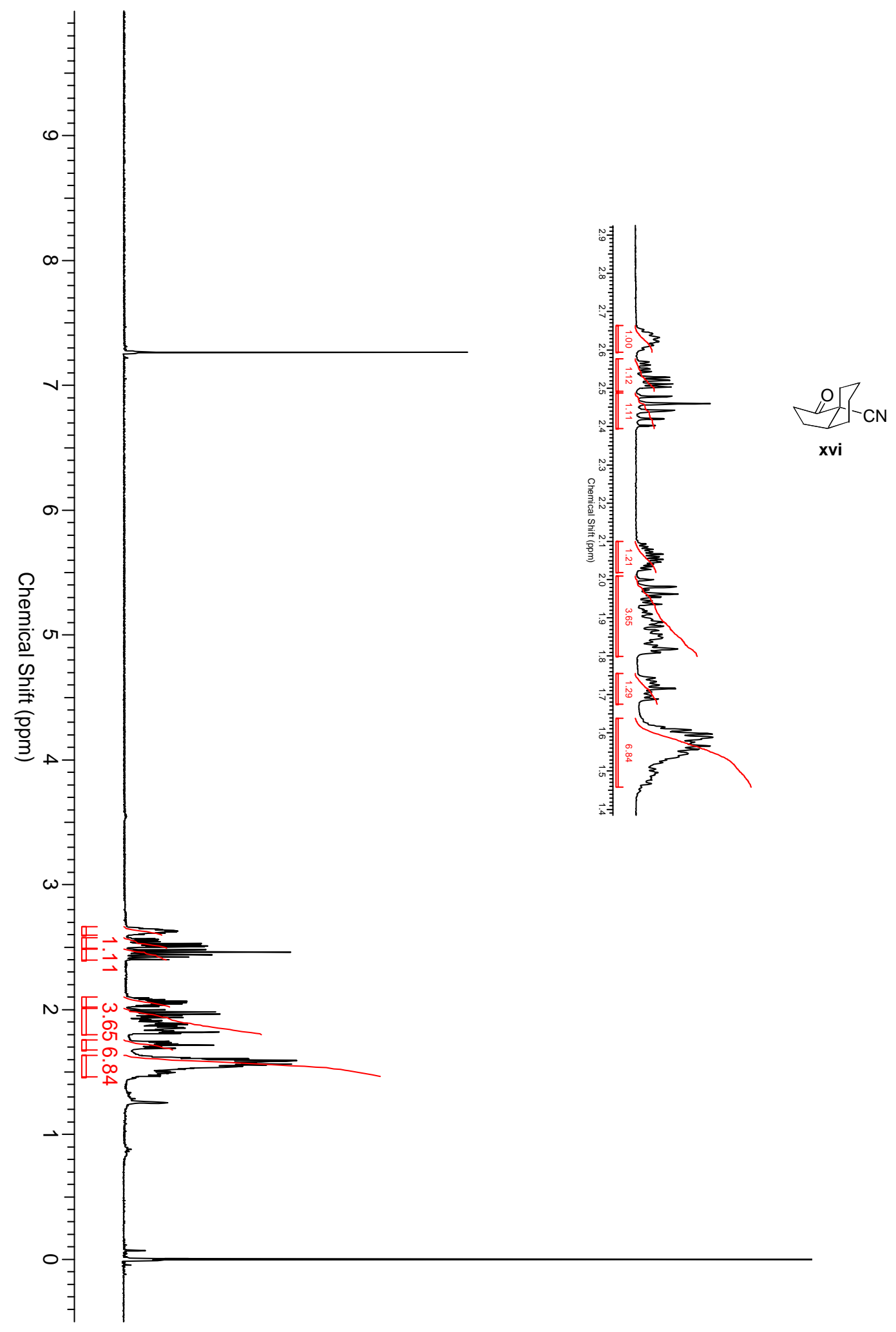




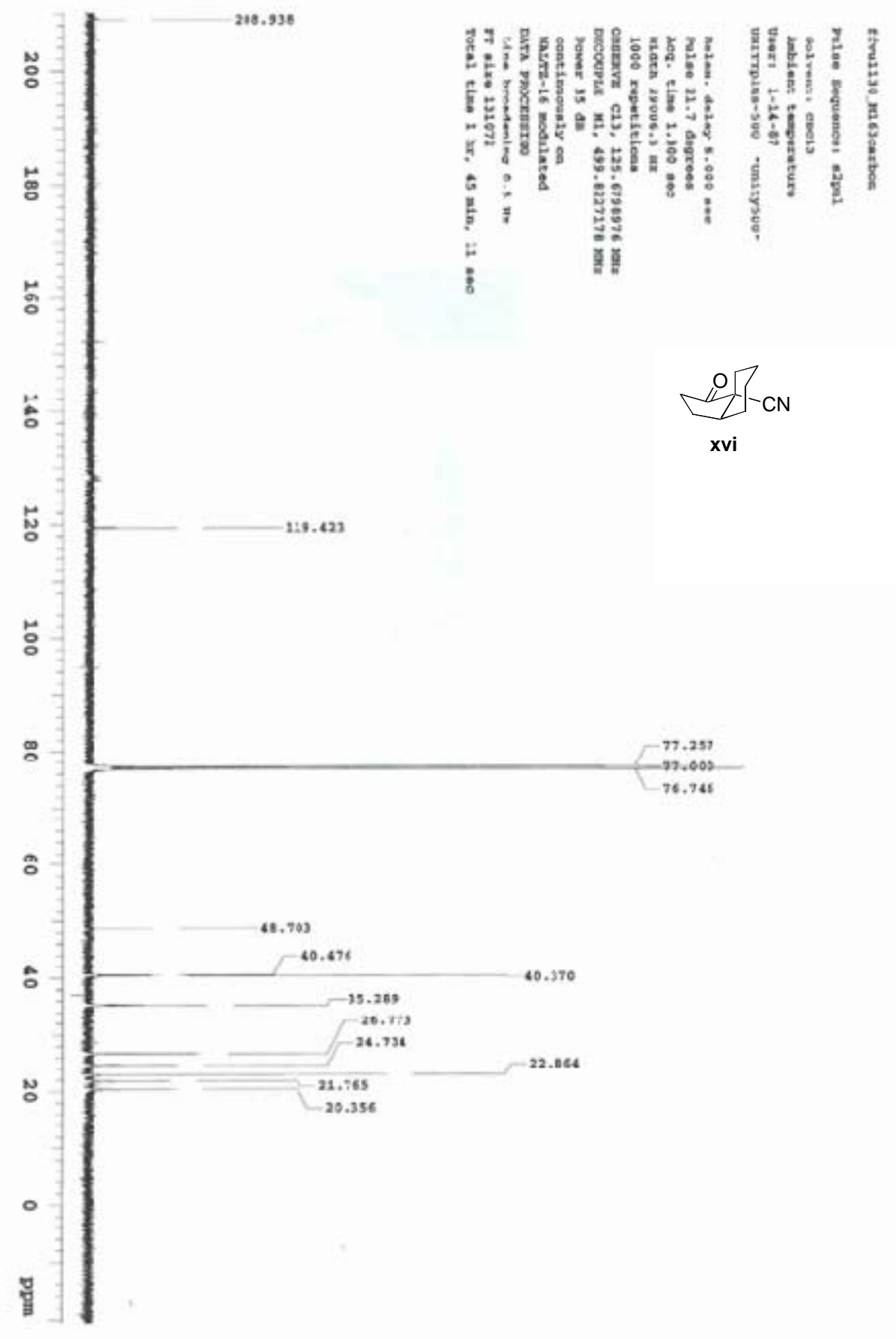




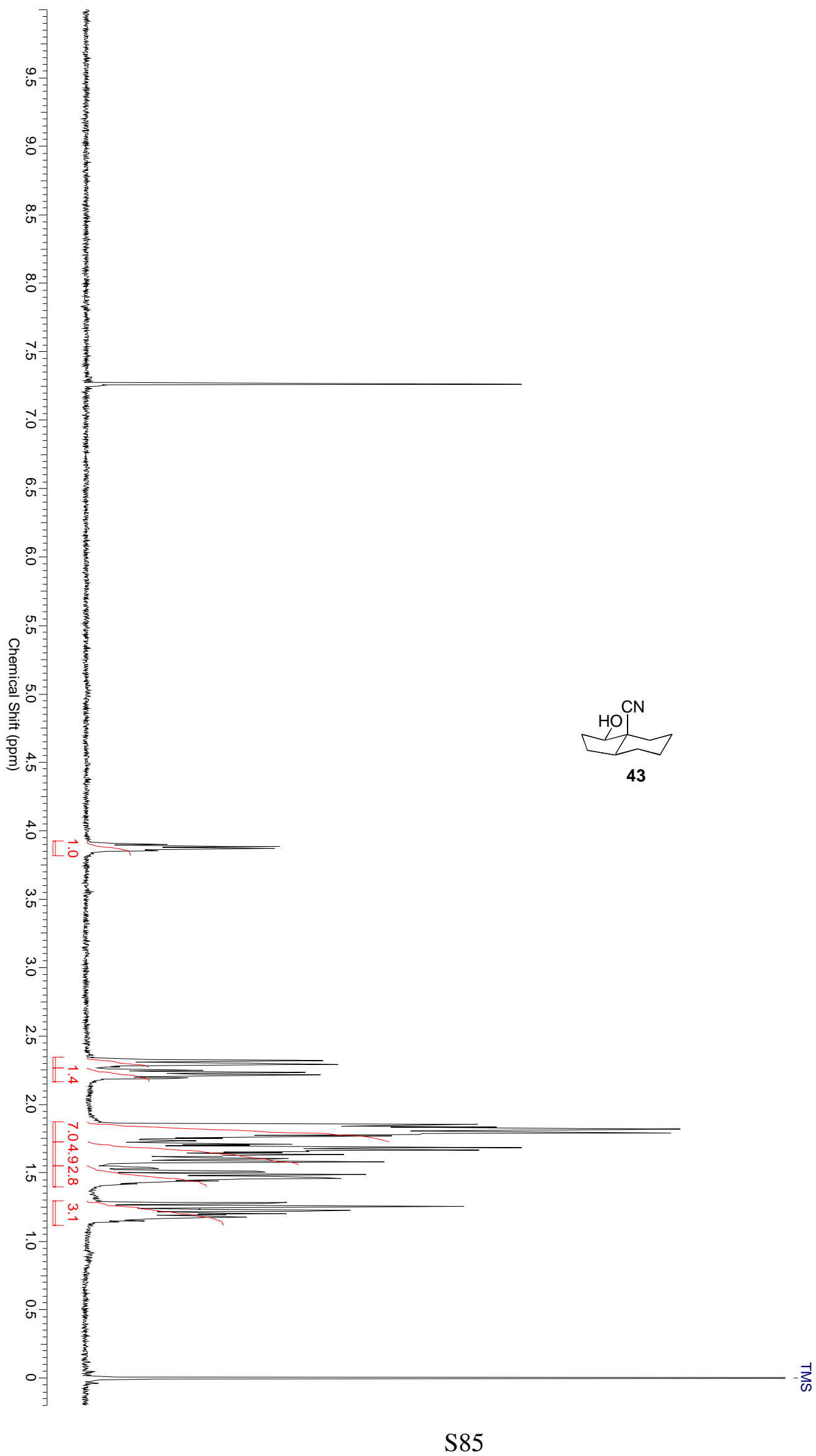




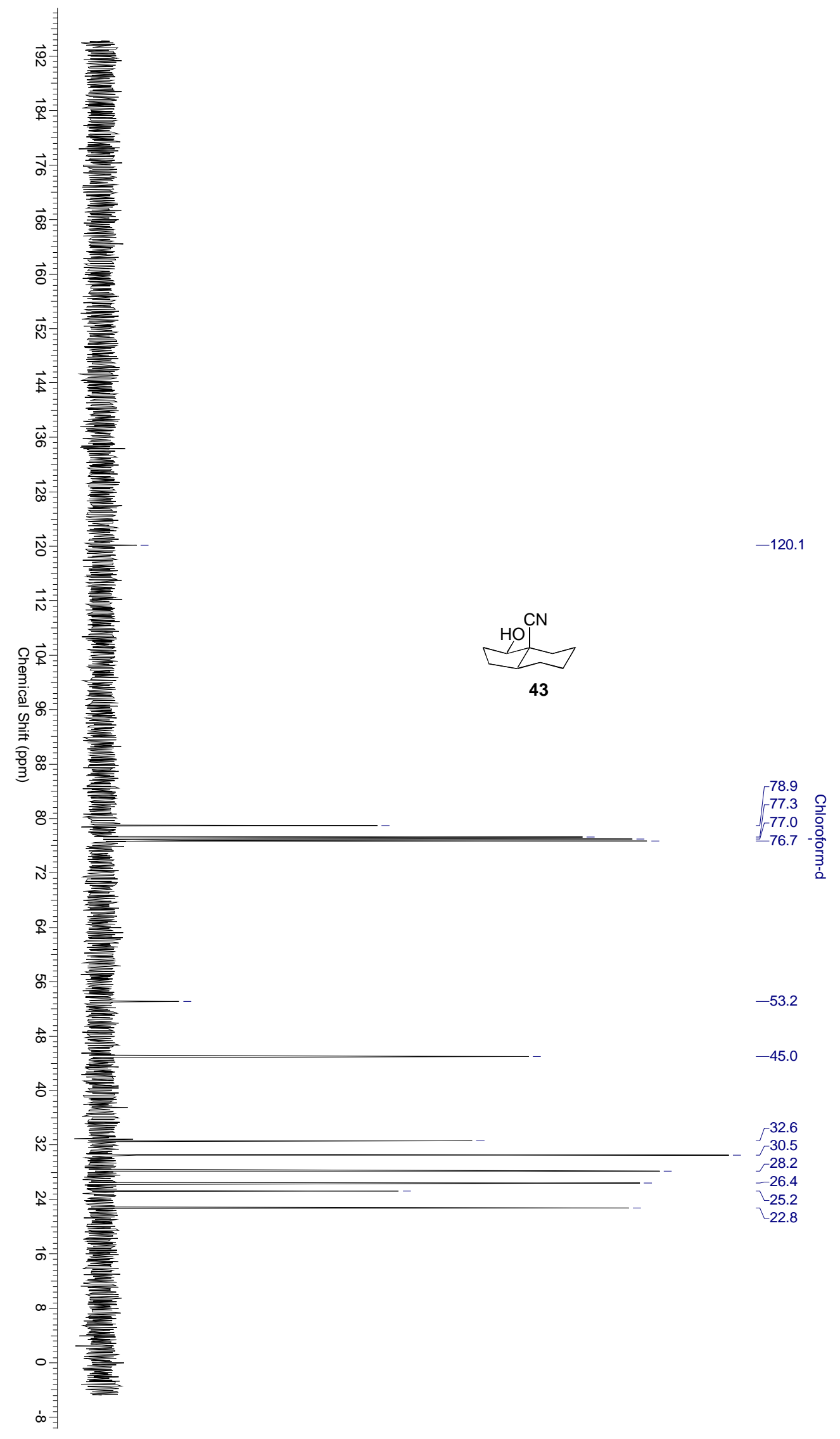




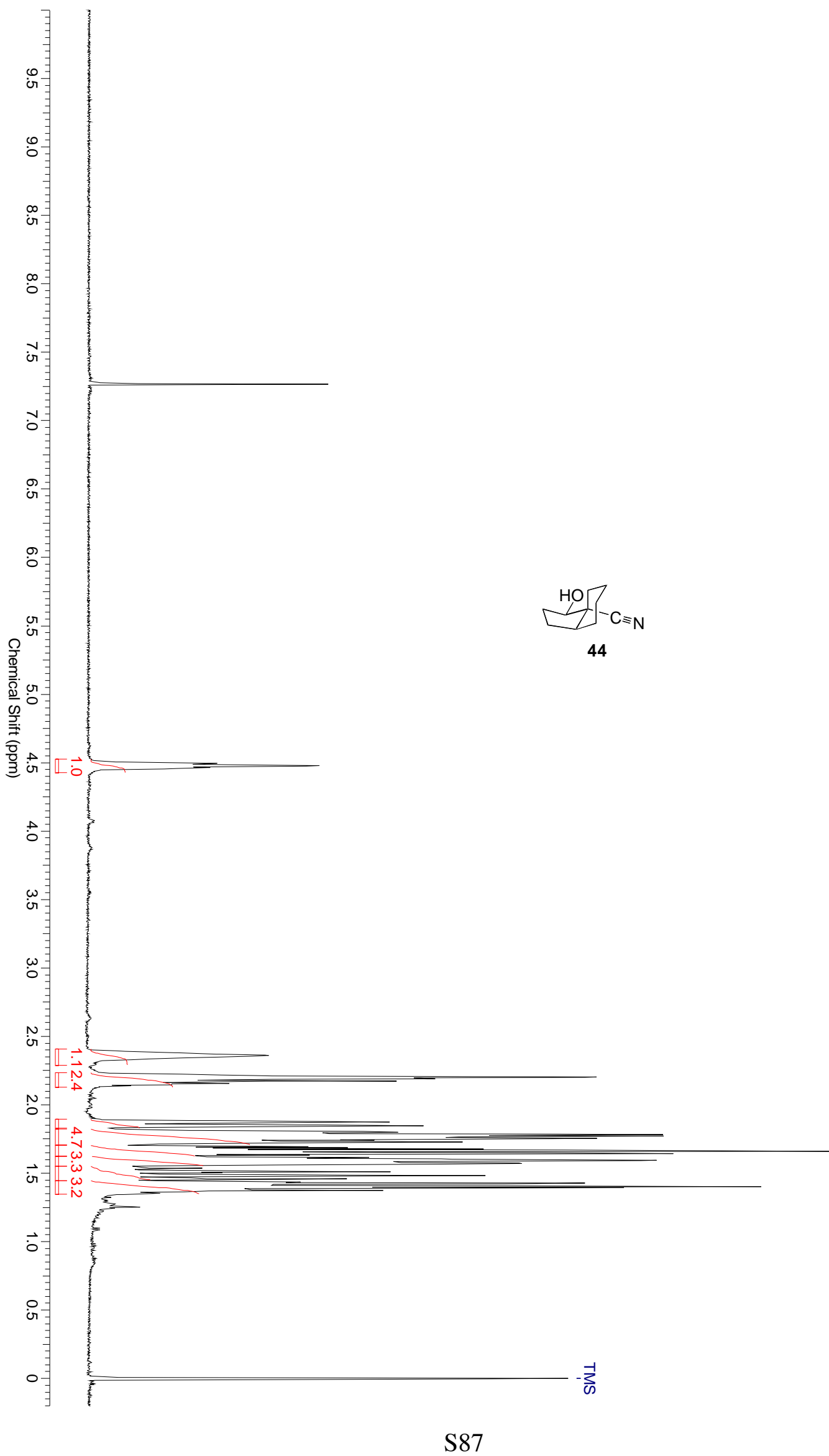




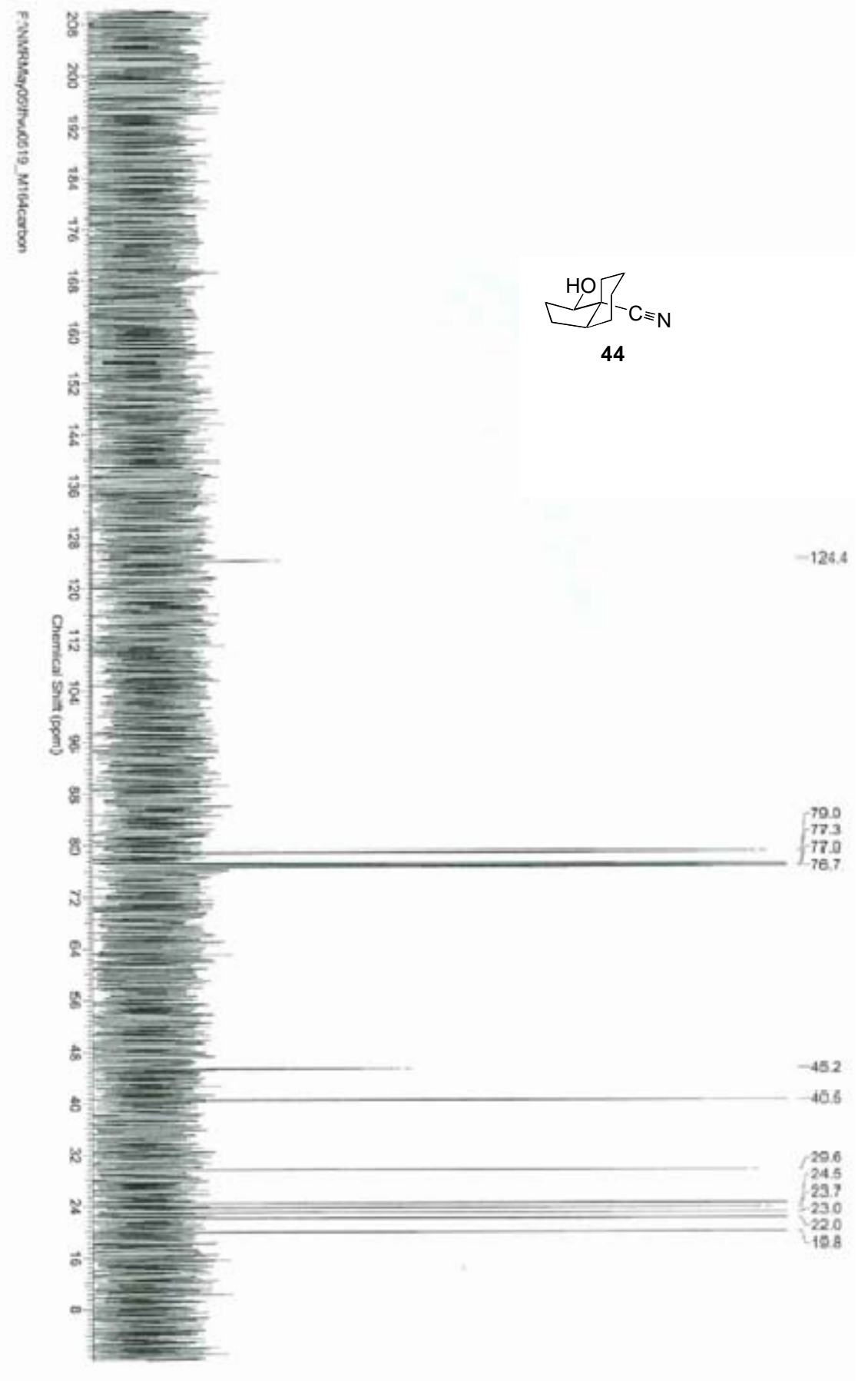




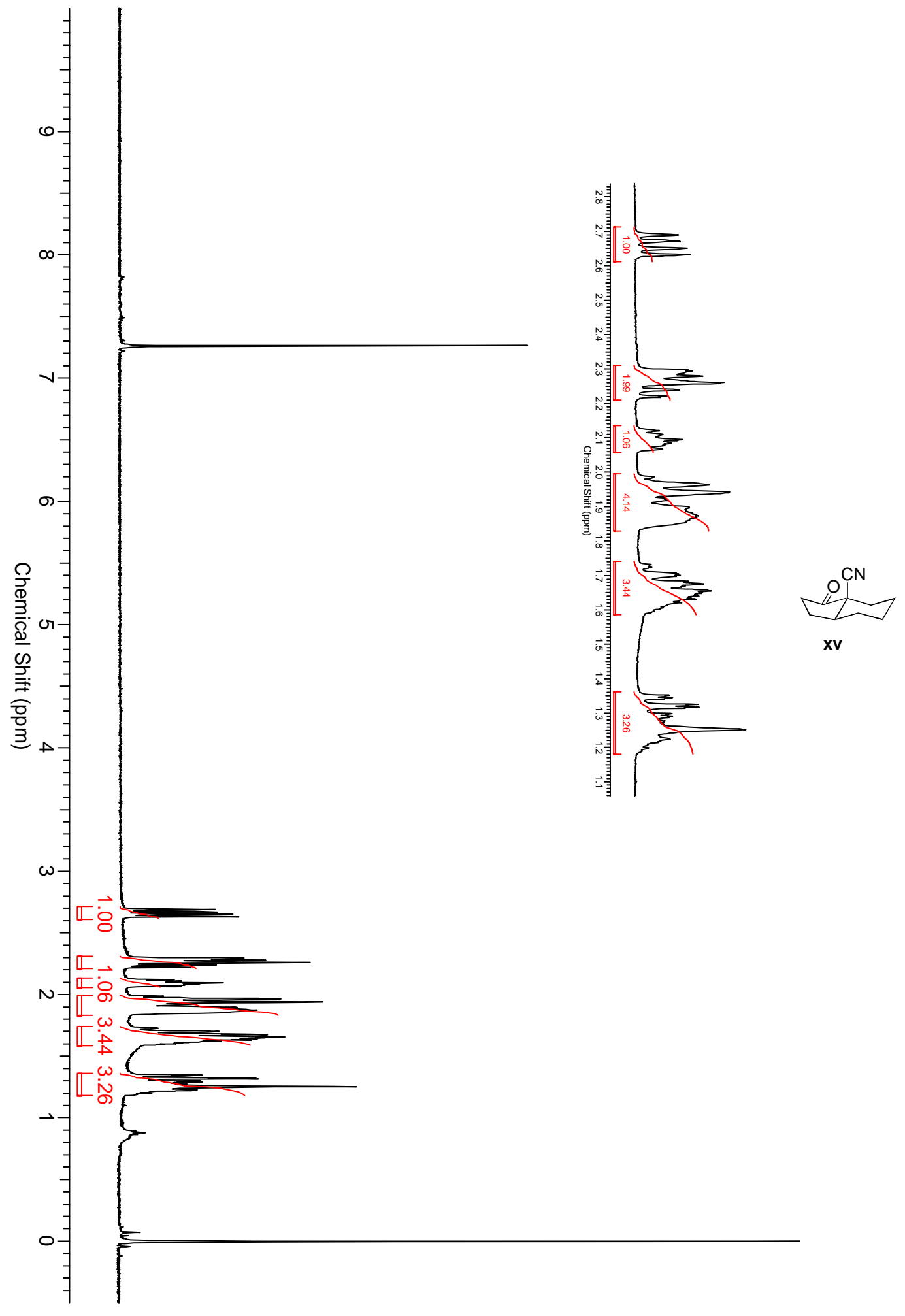




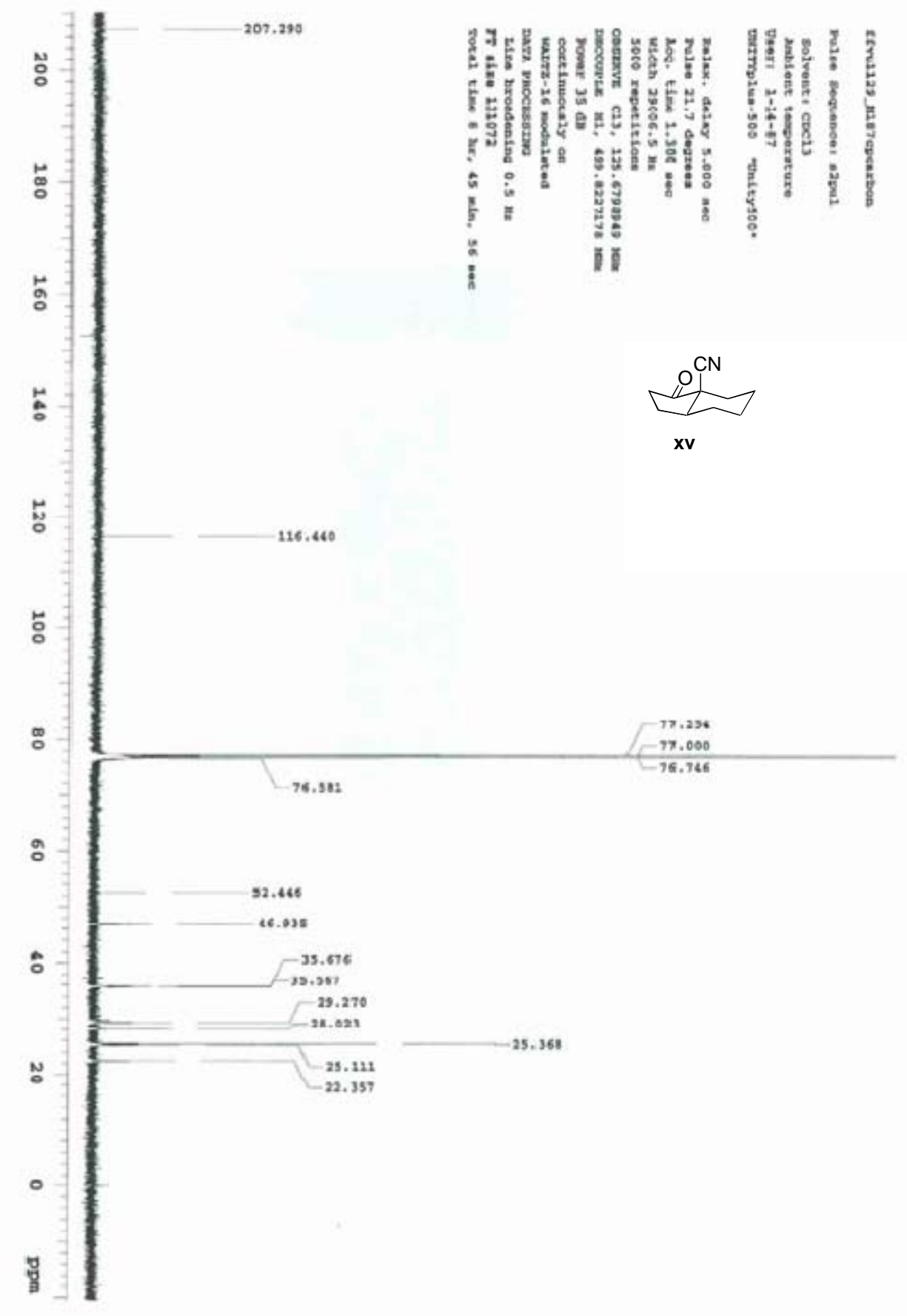




\section{References}

$1 \quad$ Fleming, F. F.; Shook, B. C.; Jiang, T.; Steward, O. W. Tetrahedron 2003, 59, 737. The broad $1 \mathrm{H}$ NMR is due to conformational equilibration as is particularly evident in the ${ }^{13} \mathrm{C}$ NMR.

2 Fleming, F. F.; Shook, B.C.; Jiang, T.; Steward, O.W. Org. Lett. 1999, 1, 1547.

3 Liu, H.-J.; Ly, T. W.; Tai, C.-L.; Wu, J.-D.; Liang, J.-K.; Guo, J.-C.; Tseng, N.W.; Shia, K.-S. Tetrahedron 2003, 59, 1209.

4 (a) Rosowsky, A.; Papoulis, A. T.; Queener, S. F. J. Med. Chem. 1998, 41, 913.

(b) Kotake, Y.; Iijima, A.; Yoshimatsu, K.; Tamai, N.; Ozawa, Y.; Koyanagi, N.; Kitoh, K.; Nomura, H. J. Med. Chem. 1994, 37, 1616.

5 Bernady, K. F.; Poletto, J. F.; Nocera, J.; Mirando, P.; Schaub, R. E.; Weiss, M. J. J. Org. Chem. 1980, 45, 4702. 